\title{
Conservation Effects Assessment Project- Wetlands Assessment in California's Central Valley and Upper Klamath River Basin
}

Open-File Report 2011-1290 



\section{Conservation Effects Assessment Project-Wetlands Assessment in California's Central Valley and Upper Klamath River Basin}

Edited by Walter G. Duffy, U.S. Geological Survey; Sharon N. Kahara, Humboldt State University; and Rosemary M. Records, U.S. Geological Survey

Open-File Report 2011-1290

U.S. Department of the Interior U.S. Geological Survey 


\section{U.S. Department of the Interior \\ KEN SALAZAR, Secretary}

\section{U.S. Geological Survey \\ Marcia K. McNutt, Director}

U.S. Geological Survey, Reston, Virginia: 2011

For more information on the USGS-the Federal source for science about the Earth, its natural and living resources, natural hazards, and the environment, visit http://www.usgs.gov or call 1-888-ASK-USGS.

For an overview of USGS information products, including maps, imagery, and publications, visit http://www.usgs.gov/pubprod.

To order this and other USGS information products, visit http://store.usgs.gov.

Suggested citation:

Duffy, W.G., Kahara, S.N., and Records, R.M., eds., 2011, Conservation Effects Assessment ProjectWetlands assessment in California's Central Valley and Upper Klamath River Basin: U.S. Geological Survey Open-File Report 2011-1290, 128 p.

Any use of trade, product, or firm names is for descriptive purposes only and does not imply endorsement by the U.S. Government.

Although this report is in the public domain, permission must be secured from the individual copyright owners to reproduce any copyrighted material contained within this report. 


\section{Contents}

Acknowledgments .............................................................................................................

Executive Summary-Ecosystem Services Derived from Wetlands Reserve Program Conservation

Practices in California's Central Valley and Oregon's Upper Klamath River Basin.................................... 1

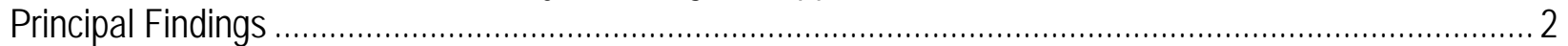

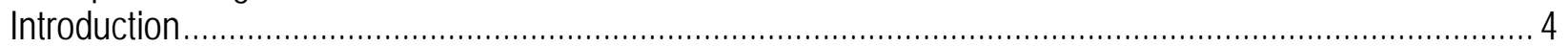

Chapter A: Habitat Assessment of Wetlands Reserve Program (WRP) in the California's

Central Valley (CCV). By Sharon N. Kahara, Rosemary M. Records, and Walter G. Duffy ........................ 13

Chapter B: Wetlands Reserve Program (WRP) Vegetation Biomass and Nutrient Content in the

California's Central Valley (CCV). By Sharon N. Kahara and Shannon J. Chapin.................................. 23

Chapter C: Wetlands Reserve Program (WRP) Soil Development in the California's

Central Valley (CCV). By Judith Z. Drexler, Sharon N. Kahara, and Rosemary M. Records ...................... 30

Chapter D: Soil Loss Reduction by Wetland Reserve Program (WRP) in California's

Central Valley (CCV). By Sharon N. Kahara and Rosemary M. Records ........................................... 35

Chapter E: Floodwater Storage Capacity of Wetland Reserve Program (WRP) in the California's

Central Valley (CCV). By Sharon N. Kahara, Rosemary M. Records, and Shannon J.Chapin .

Chapter F: Bird Use of Wetland Reserve Program (WRP) in the California's

Central Valley (CCV). By Sharon N. Kahara and Ryan DiGaudio

Chapter G: Amphibians in the California's Central Valley (CCV).

By Luke Groff and Shannon J. Chapin

Chapter H: Pollinators in Wetlands Reserve Program (WRP) Habitats in the

California's Central Valley (CCV). By Kim McFarland and Sharon N. Kahara

Chapter I: Wetlands Reserve Program (WRP) Habitat Assessment in the

Upper Klamath River Basin (UKRB). By Walter G. Duffy.....

Chapter J: Wetlands Reserve Program (WRP) Soil Properties in the Upper Klamath

River Basin (UKRB). By Rosemary M. Records and Walter G. Duffy .

Chapter K: Sediment and Nutrient Yields in the Upper Klamath River Basin (UKRB).

By Rosemary M. Records, Sharon N. Kahara, and Walter G. Duffy....

Chapter L: Amphibian Use of Wetlands Reserve Program (WRP) in the Upper Klamath River Basin.

By Walter G. Duffy and Luke Groff .....

Chapter M: Bird use of Wetlands Reserve Program (WRP) in the Upper Klamath River Basin (UKRB).

By Walter G. Duffy.

Chapter N: Fish Use of Wetlands Reserve Program (WRP) in the

Upper Klamath River Basin (UKRB). By Walter G. Duffy and Stephen Zipper .......................................... 101

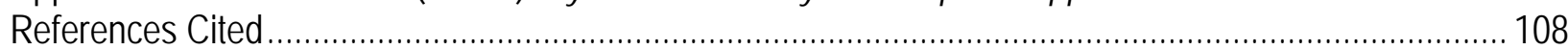

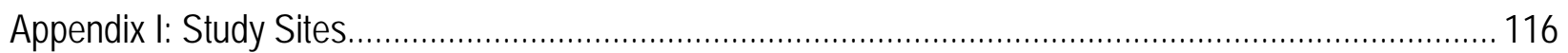

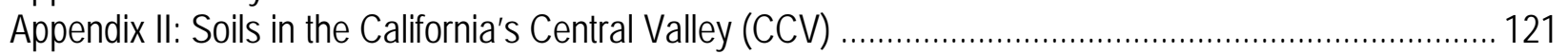

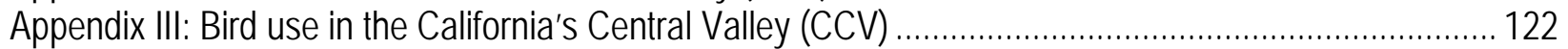

Appendix IV: Reduction of Soil Loss in the California's Central Valley (CCV) .................................... 126

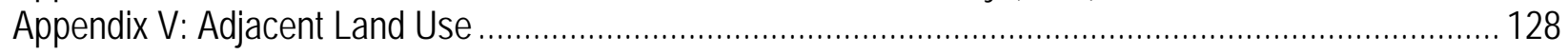




\section{Conversion Factors}

\section{SI to Inch/Pound}

\begin{tabular}{|c|c|c|}
\hline Multiply & By & To obtain \\
\hline \multicolumn{3}{|c|}{ Length } \\
\hline centimeter (cm) & 0.3937 & inch (in.) \\
\hline millimeter (mm) & 0.03937 & inch (in.) \\
\hline meter (m) & 3.281 & foot (ft) \\
\hline kilometer (km) & 0.6214 & mile (mi) \\
\hline \multicolumn{3}{|c|}{ Area } \\
\hline square meter $\left(\mathrm{m}^{2}\right)$ & 0.0002471 & acre \\
\hline hectare (ha) & 2.471 & acre \\
\hline square meter $\left(\mathrm{m}^{2}\right)$ & 10.76 & square foot $\left(\mathrm{ft}^{2}\right)$ \\
\hline hectare (ha) & 0.003861 & square mile $\left(\mathrm{mi}^{2}\right)$ \\
\hline square kilometer $\left(\mathrm{km}^{2}\right)$ & 0.3861 & square mile $\left(\mathrm{mi}^{2}\right)$ \\
\hline \multicolumn{3}{|c|}{ Volume } \\
\hline liter (L) & 0.2642 & gallon (gal) \\
\hline cubic meter $\left(\mathrm{m}^{3}\right)$ & 35.31 & cubic foot $\left(\mathrm{ft}^{3}\right)$ \\
\hline cubic meter $\left(\mathrm{m}^{3}\right)$ & 0.0008107 & acre-foot (acre-ft) \\
\hline hectare meter (ha-m) & 8.107 & acre-foot (acre-ft) \\
\hline \multicolumn{3}{|c|}{ Mass } \\
\hline microgram $(\mu \mathrm{g})$ & $3.527 \times 10^{-8}$ & ounce (oz) \\
\hline milligram (mg) & $3.527 \times 10^{-5}$ & ounce (oz) \\
\hline gram (g) & 0.035 & ounce (oz) \\
\hline kilogram (kg) & 2.205 & pound (lb) \\
\hline metric ton & 1.102 & U.S. ton (ton) \\
\hline
\end{tabular}

Temperature in degrees Celsius $\left({ }^{\circ} \mathrm{C}\right)$ may be converted to degrees Fahrenheit $\left({ }^{\circ} \mathrm{F}\right)$ as follows: ${ }^{\circ} \mathrm{F}=\left(1.8 x^{\circ} \mathrm{C}\right)+32$ 


\section{List of Abbreviations}

A

AML

ANOVA

ANR

C

CCV

CEAP

EPA

ESA

GIS

GPS

$\mathrm{K}$

LS

NAIP

NLCD

NRCS

NWR

$\mathrm{P}$

$\mathrm{R}$

RUSLE

SAC

SAN

TC

TIN

TN

TP

TUL

UKRB

USDA

USGS

UTM

RUSLE factor for average annual soil loss per unit area caused by rainfall

Arc Macro Language

Analysis of variance

Analytical Lab at University of California, Davis

RUSLE cover management factor

California Central Valley

Conservation Effects Assessment Project

U.S. Environmental Protection Agency

Endangered Species Act

Geographic information system

Global Positioning System

RUSLE soil erodibility factor

RUSLE slope length and steepness factors

National Agriculture Imagery Program

National Land Cover Dataset

Natural Resources Conservation Service

National Wildlife Refuge

RUSLE supporting practice factor

RUSLE climatic erosivity factor or species richness

Revised Universal Soil Loss Equation

Sacramento subbasin of the California Central Valley

San Joaquin subbasin of the California Central Valley

Total carbon

Triangulated Irregular Network

Total nitrogen

Total phosphorus

Tulare subbasin of the California Central Valley

Upper Klamath River Basin

U.S. Department of Agriculture

U.S. Geological Survey

Universal Transverse Mercator 


\section{Acknowledgments}

We thank all participating landowners and land managers for their generous cooperation, and staff of the Colusa, Kern, Pixley, Sacramento, and San Joaquin National Wildlife Refuges provided access and assistance. We also thank the following for their support and guidance Diane Eckles and William Effland (NRCS CEAP-Wetlands Program), Jessica Groves (NRCS California Wetlands Coordinator), NRCS field office staff, Catherine Hickey, (PRBO Conservation Science), Dirk Holstege (Agricultural and Natural Resources), Analytical Lab at University of California-Davis, Joseph Quansah (USGS National Wetland Research Center), Rick Van Remortel (Lockheed Martin Corp,), Diane Sutherland, Susan Hilton, and staff of Redwood Sciences Laboratory, Beth Werner, Mary Burke, Bryan Atkinson and other Coop Unit technicians. 


\section{Conservation Effects Assessment Project-Wetlands Assessment in California's Central Valley and Upper Klamath River Basin}

Edited by Walter G. Duffy, U.S. Geological Survey; Sharon N. Kahara, Humboldt State University; and Rosemary M. Records, U.S. Geological Survey

\section{Executive Summary-Ecosystem Services Derived from Wetlands Reserve Program Conservation Practices in California's Central Valley and Oregon's Upper Klamath River Basin}

The Wetlands Reserve Program (WRP) is one of several programs implemented by the U.S. Department of Agriculture (USDA). Since the WRP's inception in 1990, it has resulted in the restoration of approximately 29,000 hectares in California's Central Valley (CCV) and roughly 12,300 hectares in Oregon's Upper Klamath River Basin (UKRB). Both the CCV and UKRB are agricultural dominated landscapes that have experienced extensive wetland losses and hydrological alteration. Restored habitats in the CCV and UKRB are thought to provide a variety of ecosystem services, but little is known about the actual benefits afforded.

The U.S. Geological Survey (USGS) California Cooperative Fish and Wildlife Unit in collaboration with the USDA Natural Resources Conservation Service surveyed 70 WRP sites and 12 National Wildlife Refuge sites in the CCV, and 11 sites in the UKRB to estimate ecosystem services provided. In the CCV, sites were selected along three primary gradients; (1) restoration age, (2) management intensity, and (3) latitude (climate). Sites in the UKRB were assessed along restoration age and management intensity gradients where possible. The management intensity gradient included information about the type and frequency of conservation practices applied at each site, which was then ranked into three categories that differentiated sites primarily along a hydrological gradient. Information collected was used to estimate the following ecosystem services: Soil and vegetation nutrient content, soil loss reduction, floodwater storage as well as avian, amphibian, fish, and pollinator use and habitat availability.

Prior to this study, very little was known about WRP habitat morphology in the CCV and UKRB. Therefore in this study, we described these habitats and related them to ecosystem services provided. Our results indicate that although WRP in the CCV and UKRB provide a number of benefits, there may be management mediated trade-offs among ecosystem services. In this report, we considered ecosystem services at the site-specific scale; however, future work will extend to include effects of WRP relative to surrounding cropland. 


\title{
Principal Findings
}

\author{
Habitat Assessment
}

Hydrology in the CCV has been heavily modified and WRP wetlands are managed primarily to support wintering waterfowl. The most actively managed WRP wetland sites are located in the northern CCV where water availability is more predictable, although most of the wetland sites located in the southern CCV receive less hydrological manipulation due to severe water shortages. Access to water is the primary factor determining habitat composition, with less actively managed sites exhibiting high proportions of WRPs in upland zones and actively managed sites having high proportions of WRP area in wetland on average. Actively managed sites also tend to experience greater disturbance regimes than unmanaged sites due to activities such as grazing, mowing, disking, and burning to control vegetative growth. These activities have both positive and negative impacts on ecosystem service delivery.

Most sites in the UKRB are maintained under low management with less hydrological manipulation than those in the CCV. Restored wetlands in the UKRB primarily were riparian and dominated by grasses.

\section{Vegetation Biomass and Nutrient Storage}

We estimated that WRP wetlands in the CCV store between 3,000 and 400,000 metric tons of biomass in the shallow marsh zone alone. Inclusion of upland zones would no doubt yield higher estimates and should be included in future analyses. Average carbon storage on WRP generally was higher than average carbon storage of California crops, but lower than perennial crops. Carbon and biomass storage was positively correlated with precipitation, and tended to be higher in the northern CCV. We also found that carbon and biomass storage tended to decrease in older actively managed sites, likely the result of practices such as mowing, disking, grazing, and burning. Nitrogen and phosphorus storage appeared to decrease over time in sites under low or intermediate management but intensive management appeared to increase storage of these two nutrients.

\section{Soil Nutrient Storage}

Soils in all WRP wetlands surveyed in the CCV had relatively low organic carbon and nutrient concentrations that did not increase through time. Annual seasonal hydrological drawdowns (natural and artificial) result in long periods of drying resulting in oxidation of sediments and the decomposition of organic matter.

Percent nitrogen and carbon and litter depth in WRP wetlands of the UKRB tended to be higher than those of the CCV. This is likely due to the less intensive management regime of the UKRB and land use prior to enrollment in WRP.

\section{Soil Loss Reduction}

We modeled the potential effect of WRP wetlands in the CCV on soil loss mitigation using a geographic information system (GIS) based Revised Universal Soil Loss Equation algorithm. Soil loss was modeled for two restoration scenarios: (1) "before” WRP wetlands, with all WRP easements treated as cultivated cropland and (2) "after” WRP restoration, with all WRP easements treated as wetlands. We predict that conversion of cultivated cropland to wetland could mitigate soil loss of between 1 and $103 \mathrm{~kg} \mathrm{~m}^{-1} \mathrm{yr}^{-1}$. Overall soil loss mitigation services 
were estimated to be very low throughout the CCV and may have been underestimated by the model. The effect of model spatial resolution on the models' ability to accurately predict soil loss is discussed. We suggest that future analyses focus on sedimentation within WRP wetlands and potential reduction in nutrient loading to aquatic environments.

Analysis of soil loss mitigation in the UKRB is ongoing and will include an assessment of the impacts of WRP program lands in reducing soil and nutrient loads to the Sprague, Williamson, and Wood Rivers, all of which discharge into Upper Klamath Lake. Preliminary uncalibrated model results indicate higher sediment loads in the Sprague and Williamson Rivers compared to the Wood River, but higher nutrient loads in the Wood River relative to the other two rivers. Continuing analyses are expected to yield information of factors contributing to sediment loads in the UKRB.

\section{Potential Wildlife Habitat}

We surveyed more than 60 WRP easements in 2008 and 2009 to quantify avian, amphibian, and pollinator use. Our study detected more than 200 bird species in 2008 and 111 species in 2009, which is similar or higher than numbers observed on other managed sites in the same area. We found that actively managed WRP wetlands support more waterfowl than sites under low or intermediate management, which is consistent with intended goals. Despite reported water shortages, greater upland and un-restored acreage in the southern CCV, WRP wetlands are providing critical waterfowl and shorebird habitat, particularly in the early fall months. Improved access to water resources for hydrological management would greatly enhance waterfowl use in the Tulare subbasin. We suggest further investigation of the effects of hydrological management on breeding shorebird and other waterfowl use of the San Joaquin Valley. An assessment of landscape factors, such as surrounding land use and isolation, also should be conducted.

Only 20 species of birds representing 8 guilds were observed using WRP wetlands in the UKRB. Low diversity in this region may be a reflection of the brief survey period (March and July). Future surveys should be conducted across seasons to fully capture the diversity of avian species using WRP in this region.

Only four species of amphibians were detected using WRP wetlands in the CCV (that is, American bullfrogs, pacific tree frogs, western toads, and western spadefoot toads). Most amphibians were observed using older actively managed sites. These sites tend to receive regular hydrological inputs and are less disturbed by activities such as disking and mowing. Similarly, amphibian diversity in the UKRB was low with only four species detected, however, this was expected.

Pollinator species were most abundant in the southern CCV and the presence of native pollinators was positively correlated with the proportion of upland habitat. Like amphibians, pollinator species may benefit from less disturbance, however, we did not evaluate effects of disturbance in this study.

We found 11 species of fish using WRP wetlands in the UKRB. Most abundant species were larval suckers. Our surveys indicate that a high proportion of the UKRB fish community utilizes WRP wetlands, including endangered fish. 


\section{Introduction}

The U.S. Department of Agriculture (USDA) administers a variety of programs intended to assist farmers and ranchers in addressing natural resource concerns on private lands. Among these is the Wetlands Reserve Program (WRP), which was created as part of the 1990 Farm Bill (Gray, 2005) and is administered by the USDA's Natural Resources Conservation Service (NRCS). The WRP is intended to assist landowners in restoring, protecting and enhancing wetlands on agricultural lands. In California, NRCS has focused WRP on restoring freshwater wetlands that have seasonal or semi-permanent water regimes. There are currently more than 26,700 ha of WRP in the Central Valley (CCV). During 2000-2006, USDA restored more than 14,970 ha of freshwater wetlands in the CCV and Upper Klamath River Basin (UKRB). As of August 2010, there were 30 WRP easements totaling 12,340 ha in the UKRB (I. Reid, USDANRCS Oregon State Office, written commun., 2010) and 182 WRP easements totaling 29,773 ha in the CCV (D. Kwasny, USDA-NRCS California State Office, written commun., 2010).

Although WRP is widely viewed as benefiting ecological function, there has been little or no evaluation or quantification of ecological services provided to society from this program. Federal accountability initiatives require that federal agencies demonstrate the effectiveness of their programs in meeting program objectives and goals. The USDA instituted the Conservation Effects Assessment Project (CEAP) in response to this need to evaluate the effectiveness of their conservation programs. Assessing effectiveness of conservation programs will provide important guidelines to future conservation programs. The research reported here was supported by the CEAP-Wetlands program. Results of this research will be used to develop spatially explicit integrated landscape models of ecosystem service benefits expected from implementation of conservation practices or from program expansion.

\section{Objectives}

The objective of this research was to quantify ecosystem services provided by wetlands, restored or enhanced by USDA in the CCV and the UKRB (that is, WRP easements). Ecosystem services were derived from wetland functions assessed along three primary gradients: (1) climatic, (2) management, and (3) age of restoration. We measured the following ecological services: (1) native pollinator (bee) services, (2) biodiversity (amphibians, birds and fish), (3) soil erosion and sediment retention, (4) nutrient retention, including nitrogen, phosphorus and organic carbon, and (5) flood water storage.

\section{Study Areas}

\section{California's Central Valley}

California's Central Valley is an elongated sedimentary basin about $650 \mathrm{~km}$ long, $120 \mathrm{~km}$ wide and covers an area of $108,800 \mathrm{~km}^{2}$ (Schoenherr, 1992). It is often subdivided into the Sacramento River Valley in the north and San Joaquin and Tulare Valleys in the south (fig. 1). Topography is relatively flat throughout the valley, with elevation ranging from $120 \mathrm{~m}$ in the north and south to below sea level near San Francisco Bay (Schoenherr, 1992). Boundaries of the valley are not precisely defined because valley grasslands grade into oak-grassland savannas of the foothills everywhere except the south, where desert conditions exist. Climate of the valley is Mediterranean, with warm, dry summers and mild, wet winters. Air temperatures vary little throughout the valley, with average July highs approaching $38^{\circ} \mathrm{C}$ in both Bakersfield and 
Redding, although average December lows in Bakersfield $\left(2.9^{\circ} \mathrm{C}\right)$ are only slightly warmer than in Redding $\left(2.7^{\circ} \mathrm{C}\right)$. Annual precipitation, however, exhibits a distinct gradient, ranging from 16 $\mathrm{cm}$ in Bakersfield to $46 \mathrm{~cm}$ in Sacramento and $100 \mathrm{~cm}$ in Redding (Schoenherr, 1992; fig. 2). Throughout the valley, more than 90 percent of annual precipitation falls as rain during November-May.

The valley's hydrological basins historically received overland flooding from the Sacramento and San Joaquin Rivers, which fed the seasonal wetlands and vernal pools of the region. Today, the construction of flood control reservoirs, levees and dams have largely eliminated most of this flooding (Central Valley Joint Venture, 2006a).

Historically, the largest freshwater wetland area in California was associated with Tulare, Buena Vista, and Kern Lakes. These lakes contained as much as 3,360 km of freshwater marsh habitats along their shorelines, although the amount naturally varied. Today, most of the wetlands (94 percent) in the CCV have been lost. Area of wetland habitats in the CCV prior to 1900 was estimated to be 1.6-2.0 million ha (Hartman and Goldstein, 1994). By the 1980s, wetland area in the CCV had been reduced to 153,000 ha. However, wetland restoration programs have increased wetland coverage in the CCV to more than 200,000 ha in the past few decades (Central Valley Joint Venture, 2006a; Dahl, 2006). Human activities leading to wetland loss in the CCV are varied, but agricultural development and urbanization are chief among them.

\section{Upper Klamath River Basin}

The secondary study area was the Upper Klamath River Basin (UKRB) region of California and Oregon (fig. 3). The Klamath River Basin encompasses of 20,720 $\mathrm{km}^{2}$ in northern California and southern Oregon, and is located within the southern Cascade physiographic region. Much of the area east and south of Upper Klamath Lake is relatively flat and less than 1,600 m elevation. Soils of the area are of volcanic, alluvial, and wetland or lake bed origin. Palustrine emergent wetlands once covered expansive areas in this region, but most have been converted to agricultural lands. Surrounding this area, the elevation exceeds 2,000 $\mathrm{m}$ and accumulates large snowpack during wet years (National Research Council, 2007). Climate of the area grades from Mediterranean to undifferentiated upland. Annual precipitation averages $68 \mathrm{~cm}$, but varies across the area and is only $30.5 \mathrm{~cm}$ at Klamath Falls (National Research Council, 2007). Summers typically are hot and dry and winters short but cold.

Table 1. Number of contracts and area of some NRCS conservation programs in California Central Valley Counties, 2009.

\begin{tabular}{lcc}
\hline \multicolumn{1}{c}{ Program } & Number of contracts & Total contracted area (ha) \\
\hline Environmental Quality Incentives Program (EQIP ) & 1,245 & 136,267 \\
Wildlife Habitat Incentive Program (WHIP) & 9 & 488 \\
Agricultural Water Enhancement Program (AWEP) & 501 & 15,123 \\
Conservation Security Program (CSP) & 81 & 40,125 \\
Wetlands Reserve Program $^{2}$ & 182 & 29,773 \\
\hline${ }^{1}$ 2009 program data (Alan Forkey, Assistant State Conservationist for Programs, USDA-NRCS California State \\
Office, written commun., August 16, 2010) for Central Valley Counties. Not shown: Farm and Ranch Lands \\
Protection Program (FRPP) and Grassland Reserve Program (GRP). \\
${ }^{2}$ 2010 program data (Dean Kwasny, Easement Program Specialist, USDA-NRCS California State Office, written \\
commun., August 30, 2010).
\end{tabular}




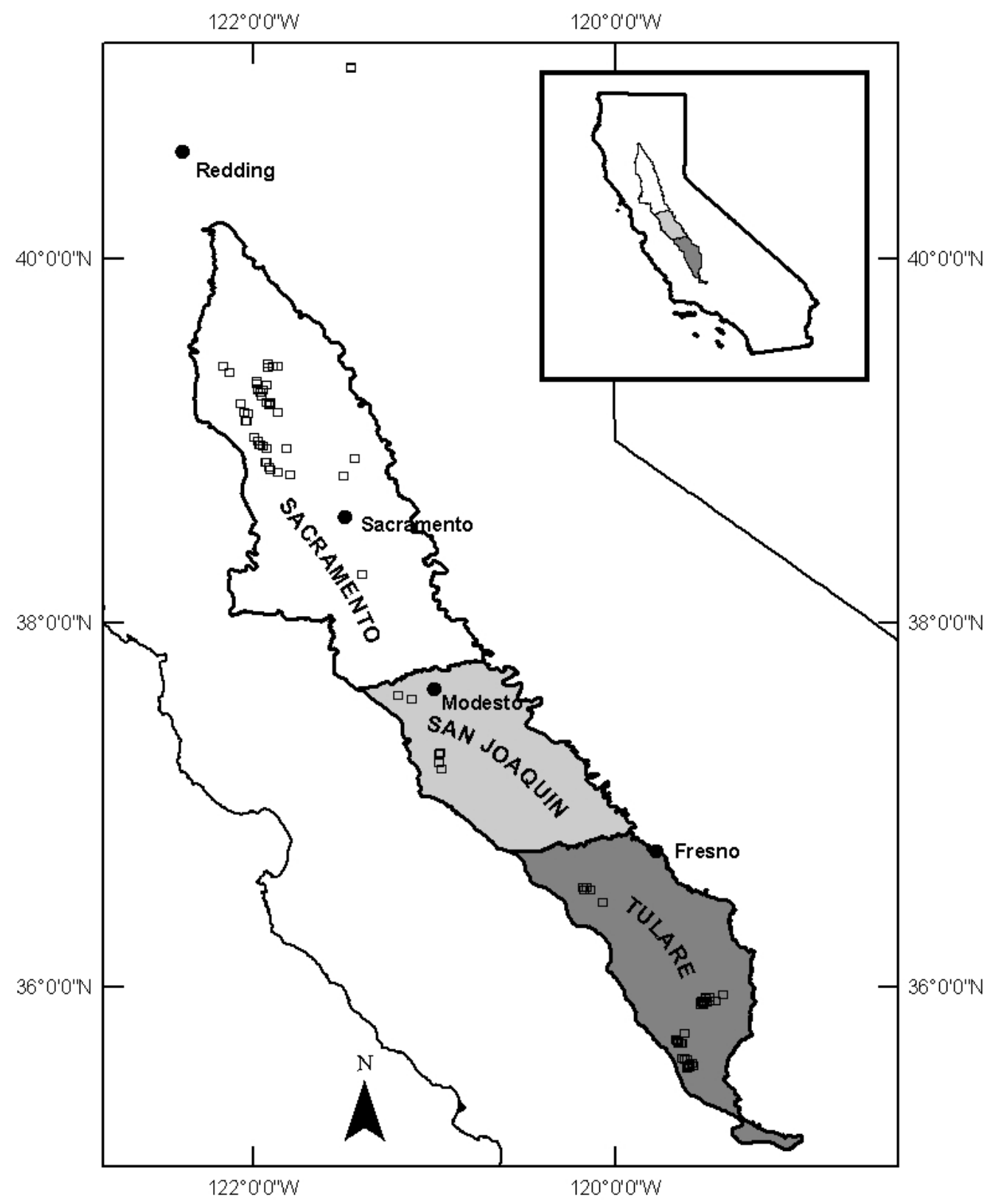

Figure 1. Location of 2008 and 2009 sampling sites (squares) in California's Central Valley. For this study, the CCV was divided into three major subbasins shown from north to south; Sacramento (white), San Joaquin (light gray), and Tulare (dark gray) (Central Valley Joint Venture, shapefile format). 


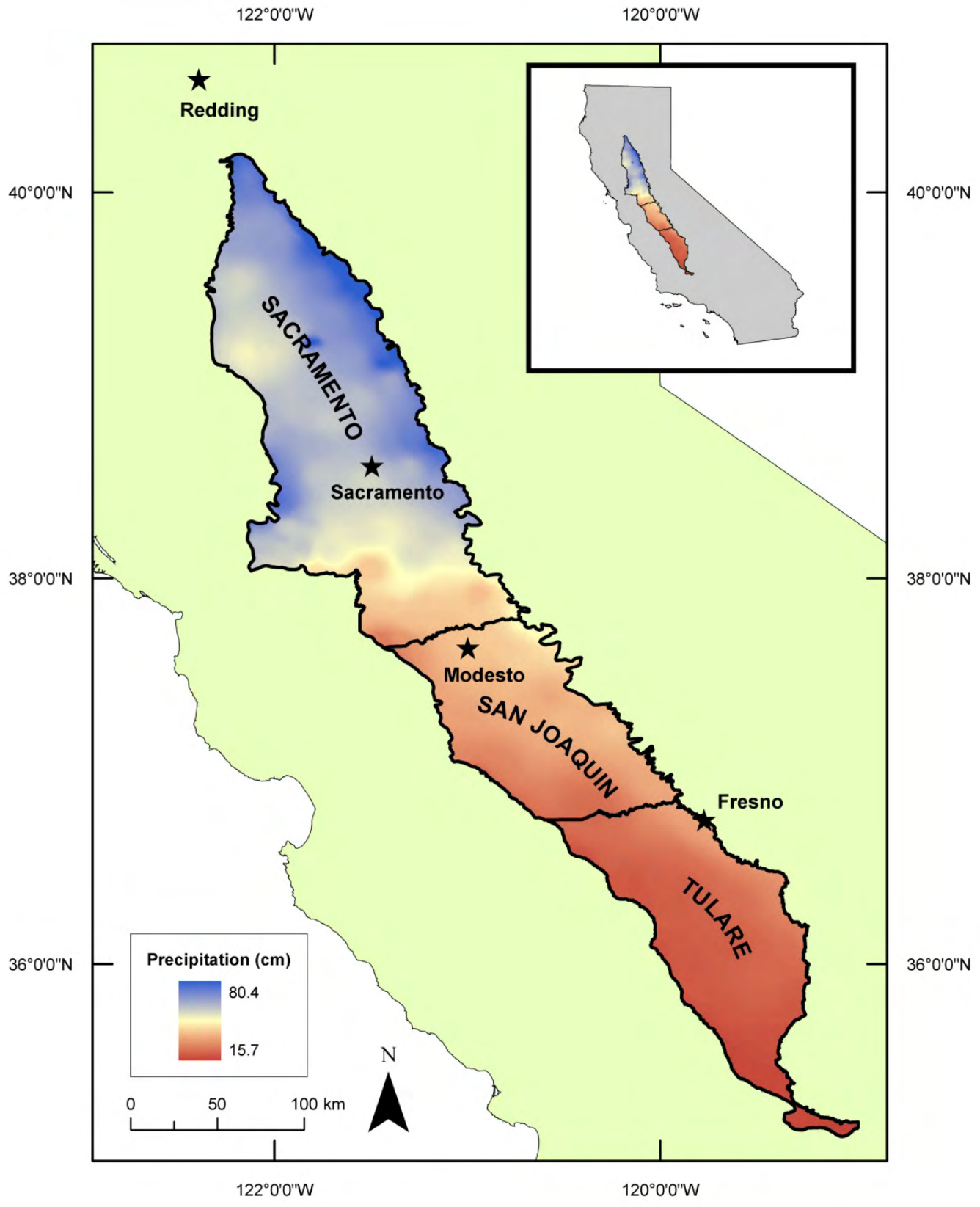

Figure 2. Average annual precipitation (1971-2000) in California's Central Valley (Central Valley Joint Venture 2006b, shapefile format; PRISM Climate Group, Oregon State University, 2006). 


\section{Methods}

\section{California's Central Valley}

In 2008, we surveyed 47 WRP easements and 11 National Wildlife Refuges (NWR) sites in the Sacramento, San Joaquin, and Tulare subbasins. National Wildlife Refuges were sampled to provide comparative data from actively managed systems over the long term. Most NWR in the CCV were initially established to provide respite from avian crop depredation and are therefore managed primarily to provide habitat for wintering waterfowl. Data collection began in February 2008. In 2009, we surveyed 50 WRP easements and five NWR sites in the CCV (appendix I, tables I1, I2, I4). Data collection in 2009 began in March.

A stratified random sampling approach was applied to select sampling units across three primary gradients; (1) management intensity, (2) restoration age, and (3) climate (primarily precipitation that varies latitudinally). Wetlands Reserve Program easements in the CCV typically are designed to facilitate water delivery and impoundment, through the construction of management units also known as “cells” (fig. 4). Units typically are separated by 1-2 m high levees that correspond to elevation changes in the landscape. Cell levee boundaries correspond to the catchment boundary of depressional wetlands of the Prairie Pothole Region wetlands or playas of the High Plains. Number and size of cells vary among WRP easements. In this study, the primary sampling unit was a single, randomly selected cell selected to represent each WRP easement. Sites were categorized into two broad age classes, relatively young (5 years or less since restoration) and relatively old (greater than 5 years since restoration). Criteria for classification by management intensity were largely based on hydrological manipulation (that is, artificial flooding frequency; appendix I, table I3). 


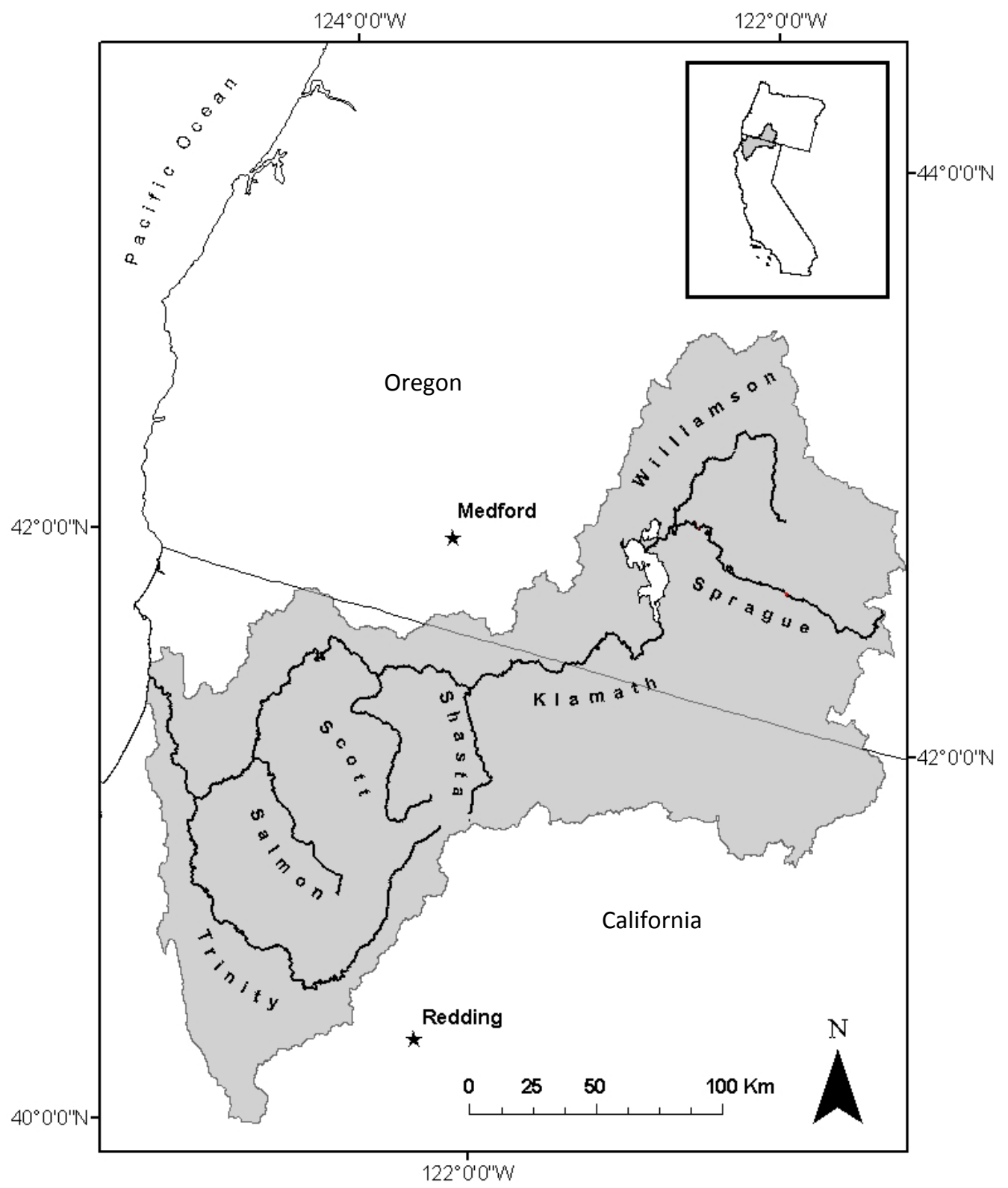

Figure 3. Location of the Klamath River Basin, California and Oregon with major rivers draining the basin. 
A
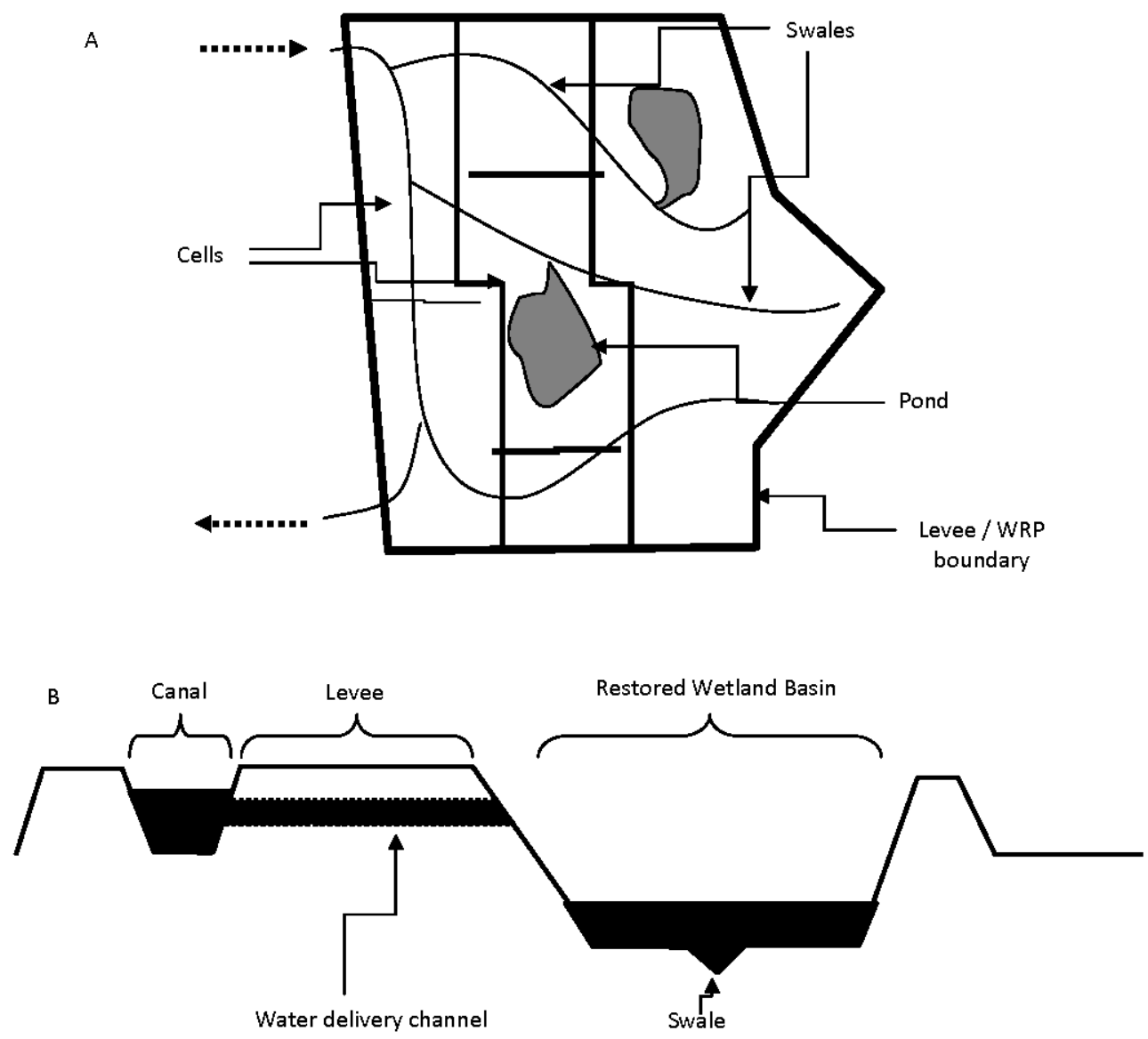

Figure 4. Conceptual diagram of typical Wetlands Reserve Program easement design showing surface view of cells, sloughs, and ponds (A) and in profile (B). Drawing is not to scale.

\section{Upper Klamath River Basin}

We surveyed a total of 11 WRP easements in the UKRB in 2008 and 2009, and also repeated sampling at three easements in 2010 (fig. 5; appendix I, table I4). The objectives of our assessment in the UKRB were (1) to provide a preliminary assessment of ecosystem services provided by WRP wetlands in this region and (2) to expand existing knowledge of WRP wetland ecosystem services in that region. The limited number of WRP easements in this region precluded a satisfactory stratification approach. In 2008, we surveyed nine wetlands for amphibians, characterized vegetation and also assessed these wetlands for their potential to support native bees. Grazing pastures are the dominant land use in the UKRB and support a limited range of flowering crops; therefore, pollinators were not sampled here. In 2009, three riparian wetlands along the Sprague River were surveyed for wetland soil nitrogen, phosphorus and carbon content, plant community composition, as well as fish and bird use. In 2010, we repeated surveys of fish in three wetlands along the Sprague River. 


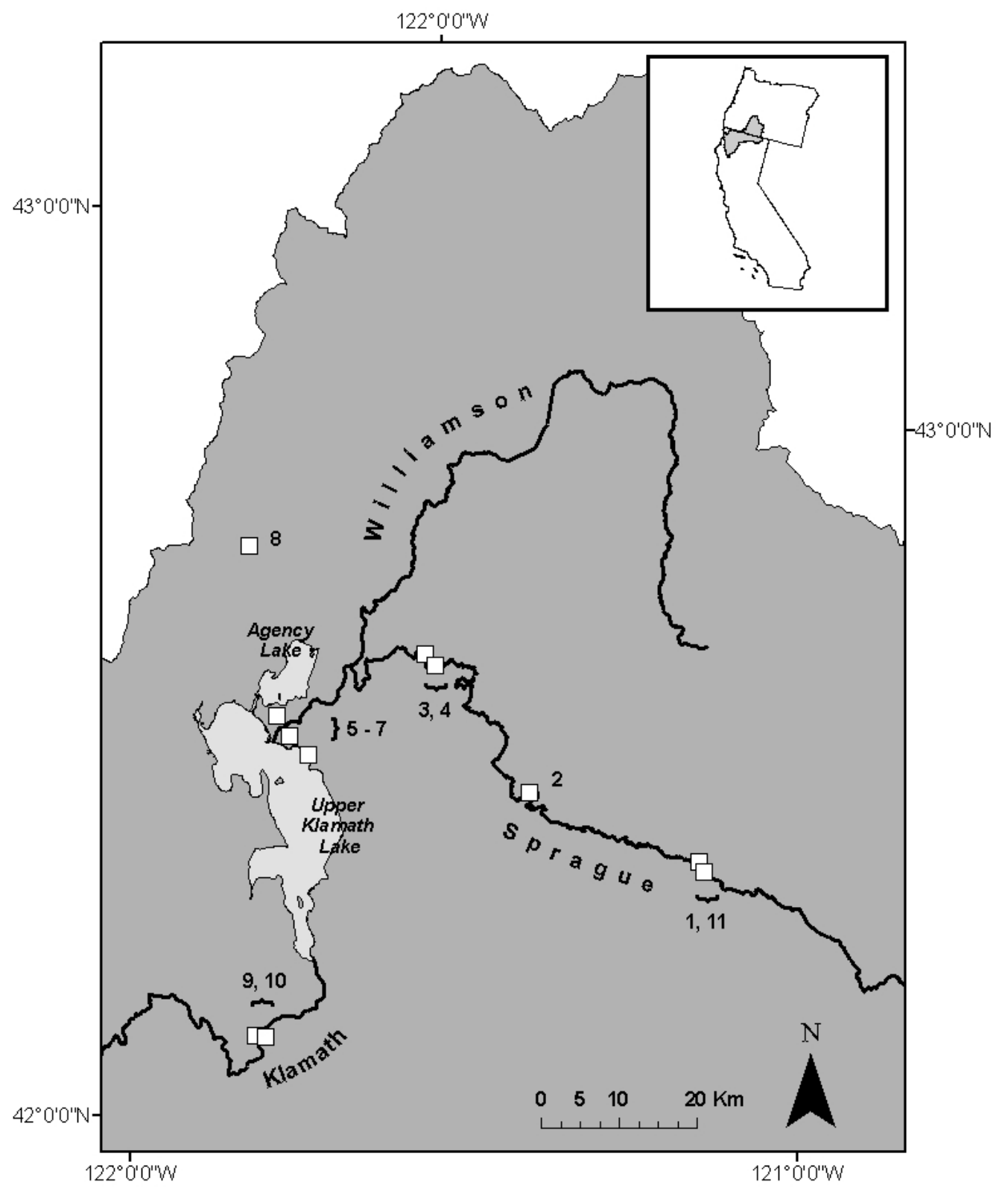

Figure 5. Location of the survey sites along the Klamath and Sprague Rivers. Site 8 lies along Sevenmile Creek and Short Creek. 
This page left intentionally blank 


\title{
Chapter A: Habitat Assessment of Wetlands Reserve Program (WRP) in the California's Central Valley (CCV)
}

\author{
By Sharon N. Kahara, Humboldt State University; and Rosemary M. Records and Walter G. Duffy, U.S. \\ Geological Survey \\ Introduction
}

California’s Central Valley comprises approximately 10 percent of the total area of California. Prior to extensive agricultural conversions in the 1800s, the CCV predominantly was covered in grassland in included more than 1,618,000 ha of wetland habitat (Schoenherr, 1992). More than 95 percent of depressional wetlands and 90 percent of riparian wetlands have been lost. Much of what remains is privately managed (Dennis, and others, 1984; Central Valley Joint Venture, 2006a).

Since its inception in the 1990s, the Wetlands Reserve Program has restored more than 26,700 ha of wetland habitat in the CCV. Although these habitats are assumed to reflect historical wetland conditions, little is known about the composition of these restored areas, and how they compare to wetlands that were lost.

Changes in the hydrology of the CCV have been drastic and have influenced wetland habitats. Historically, seasonal wetlands in the CCV were filled by overbank flooding from the Sacramento and San Joaquin Rivers during winter and early spring. Low-lying areas of the western Sacramento subbasin (around the Delta and Yolo Basins) were tidally influenced by San Francisco Bay. The Tulare subbasin held up to 20,200 ha of permanent, semi-permanent, and seasonal freshwater wetlands. During wet years, wetlands in the Tulare subbasin would overflow north to the San Joaquin subbasin.

Today, flooding is controlled by dams, levees, drainage facilities, and pumps that control the flow of water through a network of drainage canals. Water supplies in the Sacramento and San Joaquin subbasins although restricted, are more reliable than the Tulare subbasin. During the latter one-half of the 19th century and early part of the 20th century, marshes and lakes of the Tulare subbasin were drained for agricultural conversion. Today, wetland area in the Tulare subbasin is less than 1 percent of the historical area and this subbasin is the driest part of the CCV. Although most managed wetlands in the CCV are filled with agricultural drainwater, surface-water supplies in the Tulare subbasin are unreliable, necessitating groundwater extraction, which can be financially restrictive.

Flooding schedules in managed wetlands may significantly impact wildlife use. Prior to the 1850s, wetland hydrology was driven by natural processes and shorebirds breeding in the summer relied on evaporating seasonal and semi-permanent wetlands. Currently, wetland hydrology is managed and management regimes emphasize fall flooding that is better suited to waterfowl arriving later in the fall.

We surveyed landowners, land managers, NRCS biologists, and WRP records to quantify the distribution of habitat types and management practices in WRP easements. We analyzed these across three gradients; climate (latitudinal), management intensity, and restoration age. 


\section{Methods}

Management Surveys and Interviews

Data regarding conservation practices and management implemented on WRP easements in the CCV were obtained from the NRCS state office in Davis, California, and from interviews with landowners or land managers.

\section{Site Surveys}

Proportions of each site in upland, wetland (with emergent aquatic vegetation) and open water were made using visual surveys at each site. Surveys were conducted along four transects extending from the perimeter of each cell to the center. Adjacent land use also was recorded (appendix V, table V1). Information on habitat characteristics of each representative cell was gathered following procedures developed by USGS-Northern Prairie Wildlife Research Center (Kantrud and Newton, 1996).

Transect measurements were limited to $100 \mathrm{~m}$ in large WRPs $\left(>100 \mathrm{~m}^{2}\right)$ and distances between transect locations were not fixed. Width $(\mathrm{m})$ of all vegetation zones bisected by transects was estimated and water depth $(\mathrm{cm})$ recorded. Vegetation zones were delineated by plant species composition and water depth. Zones dominated by flood intolerant plants and grasses were classified as upland. Zones comprised of flood tolerant species were further subdivided into wet meadow, shallow marsh, and deep marsh zones depending on the plant guilds present (following Stewart and Kantrud, 1971). A 1-m² quadrat was randomly placed in each zone to estimate vegetation cover (percent) and visual obstruction at plot center (after Daubenmire, 1959; Robel and others, 1970).

\section{Statistical Analyses}

Average width (meters) of upland, wetland and open water zones were analyzed along three gradients: latitudinal (subbasin), age, and management intensity. Habitat data were not normally distributed and were analyzed using Kruskall-Wallis ANOVA and Mann-Whitney U test.

\section{Results}

\section{Management}

Seventy-five percent of all sites surveyed were flooded on an annual basis, but only about one-half were actively drained; the remainder simply lost water by evaporation. Overall, about 80 percent of WRP managers targeted waterfowl in their management, although about 40 percent mentioned shorebirds as a management goal (table A1). About one-quarter of all sites were managed specifically for upland species including doves, pheasant, and quail. About 40 percent are actively grazed, and most are disked, mowed, or sprayed to control weeds. Almost 30 percent have been burned since restoration and more than 20 percent or WRP managers mentioned that they or the county had sprayed waterways in or around the WRP to control mosquitoes, but mosquito control varied among subbasins (table A1). A greater proportion of young WRPs was managed for shorebirds and received active management techniques than did old WRPs (table A2). Defined management activities were most often applied at an intermediate or high intensity (table A3). 
The majority of sites in California were categorized as intermediately managed (32.9 percent), and 23 percent were actively managed and 17 percent were inactively managed or unmanaged. More than 8 percent of all sites were reported unrestored. The largest proportion of inactively managed WRPs was in the Tulare subbasin (39 percent). More than one-half of all intermediately and actively managed sites were located in the Sacramento subbasin (57 and 68 percent, respectively). Relative proportions of WRP by management intensity within each basin are given in table A4. At the start of this study in 2008, most WRP easements had been restored after 2003 (38 percent), and 23 percent were restored prior to 2003 (table A5).

Table A1. Proportion of sites in California's Central Valley in which specific management activities were applied by subbasin.

[Information was derived from interviews with 77 landowners, managers, and NRCS staff]

\begin{tabular}{lccc}
\hline \multicolumn{1}{c}{ Management activity } & \multicolumn{3}{c}{ Subbasin } \\
\cline { 2 - 4 } & Sacramento & San Joaquin & Tulare \\
\hline Annual flood & 83.3 & 83.3 & 59.1 \\
Active drawdown & 50.0 & 33.3 & 56.5 \\
Waterfowl & 90.2 & 100.0 & 73.1 \\
Shorebirds & 27.3 & 50.0 & 59.3 \\
Other birds & 27.3 & 16.7 & 28.6 \\
Grazed & 21.6 & 66.7 & 62.5 \\
Disked & 53.7 & 40.0 & 55.6 \\
Mowed & 71.4 & 80.0 & 60.9 \\
Sprayed & 59.5 & 60.0 & 76.9 \\
Mosquito spray & 4.4 & 0.0 & 48.4 \\
Burned & 28.9 & 60.0 & 19.0 \\
\hline
\end{tabular}

${ }^{1}$ Upland species such as pheasant and quail.

Table A2. Proportion of sites in California's Central Valley in which specific management activities were applied categorized by restoration age.

[Information was derived from interviews with 77 landowners, managers, and NRCS staff]

\begin{tabular}{lcc}
\hline \multicolumn{1}{c}{ Management activity } & \multicolumn{2}{c}{ Restoration Age } \\
\cline { 2 - 3 } & Old $(>5$ yrs $)$ & Young $(<5$ yrs $)$ \\
\hline Annual flood & 79.3 & 72.2 \\
Active drawdown & 51.9 & 53.1 \\
Waterfowl & 82.4 & 87.2 \\
Shorebirds & 20.0 & 56.1 \\
Other birds $^{1}$ & 22.9 & 29.7 \\
Grazed & 27.6 & 48.7 \\
Disked & 45.5 & 61.0 \\
Mowed & 59.3 & 75.7 \\
Sprayed & 71.4 & 100.0 \\
Mosquito spray & 16.2 & 26.1 \\
Burned & 33.3 & 25.0 \\
\hline
\end{tabular}

${ }^{1}$ Upland species such as pheasant and quail. 
Table A3. Proportion of sites in California's Central Valley in which specific management activities were applied by management intensity.

[Information was derived from interviews with 77 landowners, managers, and NRCS biologists]

\begin{tabular}{lccc}
\hline \multirow{2}{*}{ Management activity } & \multicolumn{3}{c}{ Management Intensity } \\
\cline { 2 - 4 } & Low & Intermediate & High \\
\hline Annual flood & 47.1 & 82.6 & 87.5 \\
Active drawdown & 16.7 & 59.1 & 62.5 \\
Waterfowl & 64.3 & 85.2 & 93.5 \\
Shorebirds & 18.8 & 53.8 & 39.4 \\
Other birds ${ }^{1}$ & 31.3 & 34.8 & 18.8 \\
Grazed & 35.7 & 52.0 & 32.1 \\
Disked & 18.8 & 63.0 & 63.3 \\
Mowed & 42.9 & 73.1 & 78.3 \\
Sprayed & 66.7 & 85.2 & 100.0 \\
Mosquito spray & 14.3 & 28.6 & 18.2 \\
Burned & 7.1 & 27.3 & 39.3 \\
\hline
\end{tabular}

${ }^{1}$ Upland species such as pheasant and quail.

Table A4. Distribution of WRP easements by management intensity within each subbasin and in the intermountain region.

\begin{tabular}{lccccc}
\hline \multirow{2}{*}{ Location } & \multicolumn{5}{c}{ Management Intensity ( percent) } \\
\cline { 2 - 6 } & Low & Intermediate & Active & Not restored & No data \\
\hline Sacramento & 9.8 & 48.0 & 40.2 & 0.0 & 2.0 \\
San Joaquin & 3.0 & 18.2 & 9.1 & 3.0 & 66.7 \\
Tulare & 27.9 & 19.7 & 16.4 & 36.1 & 0.0 \\
\hline
\end{tabular}

Table A5. Proportion of WRP restoration easements in different age categories in California.

["Young" sites are $\leq 5$ years since restoration; "Old" are $>5$ years]

\begin{tabular}{lccc}
\hline \multirow{2}{*}{ Location } & \multicolumn{3}{c}{ Percent by subbasin } \\
\cline { 2 - 4 } & Young $(\leq 5 \mathrm{yr})$ & Old $(>\mathbf{5}$ yr $)$ & No data \\
\hline Sacramento & 40 & 54 & 27 \\
San Joaquin & 7 & 4 & 23 \\
Tulare & 27 & 19 & 23 \\
\hline
\end{tabular}




\section{Site Characteristics}

Sites in the Tulare subbasin exhibited significantly larger upland zones, followed by the San Joaquin and Sacramento subbasins (fig. A1). Wet meadow zones dominated by annual, flood tolerant species and the open water zone were significantly larger in the Sacramento subbasin (figs. A2 and A3). Wetland zones did not differ by management. Younger sites exhibited larger upland zones, while older sites had significantly larger wet meadow and shallow marsh zones (figs. A4, A5, and A6).

\section{Wetlands Reserve Program Compared to National Wildlife Refuges}

We compared habitat in WRP to National Wildlife Refuges. Wetlands Reserve Program easements under low management had significantly larger upland areas $(t(16)=-2.4, P=0.03)$, although NWR had larger wet meadows $(t(16)=-4.8, \mathrm{P}<0.001$, fig. A2), shallow marshes $(t$ $(16)=-6.5, \mathrm{P}<0.001)$ and open water zones $(t(16)=-3.1, \mathrm{P}<0.001$, fig. A3). National Wildlife Refuges also exhibited denser vegetative cover in the wet meadow $(t(16)=-2.2, \mathrm{P}=0.05)$ and shallow marsh areas $(t(16)=-2.4, \mathrm{P}=0.03)$.

We compared habitat in WRP to National Wildlife Refuges. Wetlands Reserve Program easements under low management had significantly larger upland areas, although NWR had larger wet meadows, shallow marshes, and open water zones as well as denser vegetative cover in the wet meadow and shallow marsh areas. Similarly, intermediate and actively managed WRP sites exhibited smaller wet meadow, shallow marsh and open water than NWRs.

Similarly, intermediately managed WRPs had larger upland zones $(t(18)=-2.5, \mathrm{P}=$ 0.02), smaller wet meadow $(t(18)=-5.1, \mathrm{P}<0.001)$, shallow marsh $(t(18)=-6.9, \mathrm{P}<0.001)$, and open water $(t(18)=-3.3, \mathrm{P}=0.004)$ than NWRs.

Actively managed WRPs also had larger upland zones $(t(15)=2.5, \mathrm{P}=0.03)$, smaller wet meadows $(t(15)=-4.6, \mathrm{P}<0.001)$, smaller shallow marshes $(t(15)=-6.1, \mathrm{P}<0.001)$, and smaller open water zones $(t(15)=-2.9, \mathrm{P}=0.01)$. Vegetation in the wet meadows of NWR sites was denser than that of actively managed sites $(t(15)=-3.2, \mathrm{P}=0.006)$. 


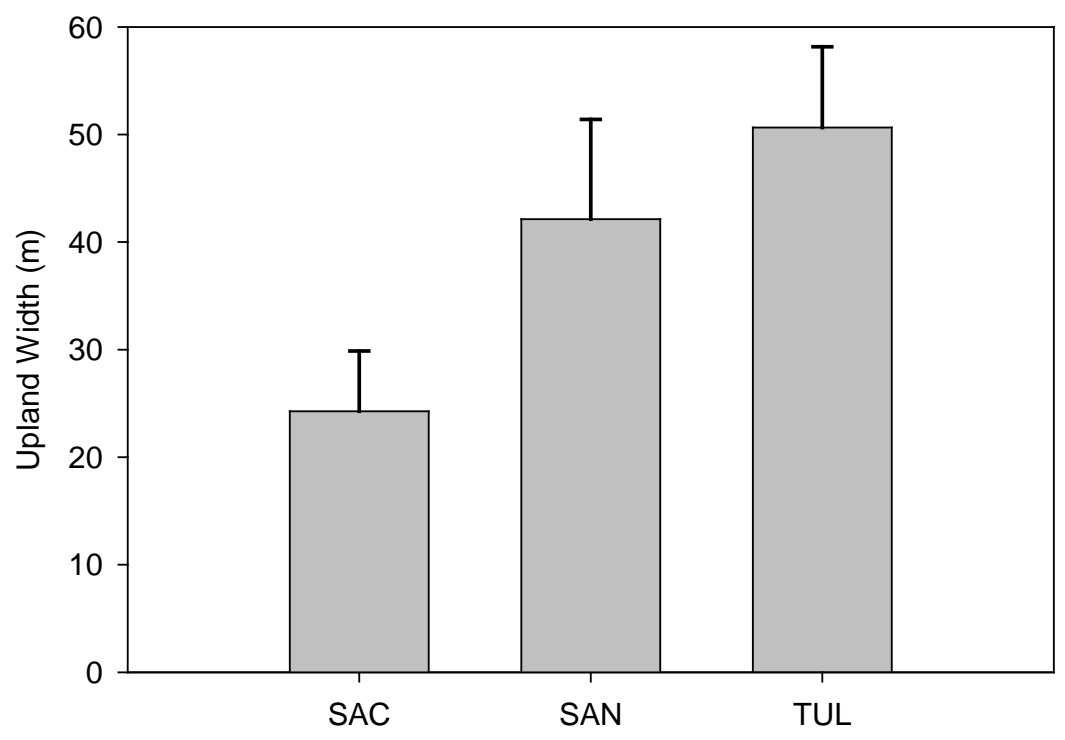

Figure A1. Average width $(\mathrm{m})$ of the upland zone by subbasin. $\mathrm{SAC}=$ Sacramento, $\mathrm{SAN}=$ San Joaquin and TUL = Tulare. Bars are standard errors.

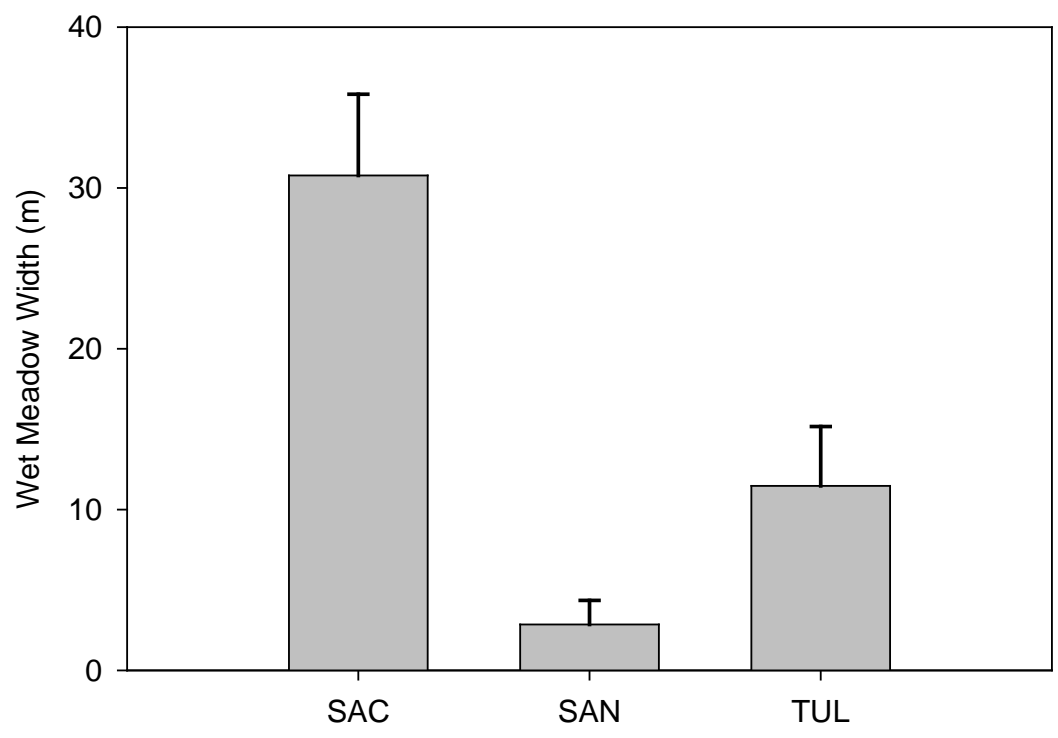

Figure A2. Average width $(\mathrm{m})$ of the wet meadow zone by subbasin. $\mathrm{SAC}=$ Sacramento, $\mathrm{SAN}=\mathrm{San}$ Joaquin and TUL $=$ Tulare. Bars are standard errors. 


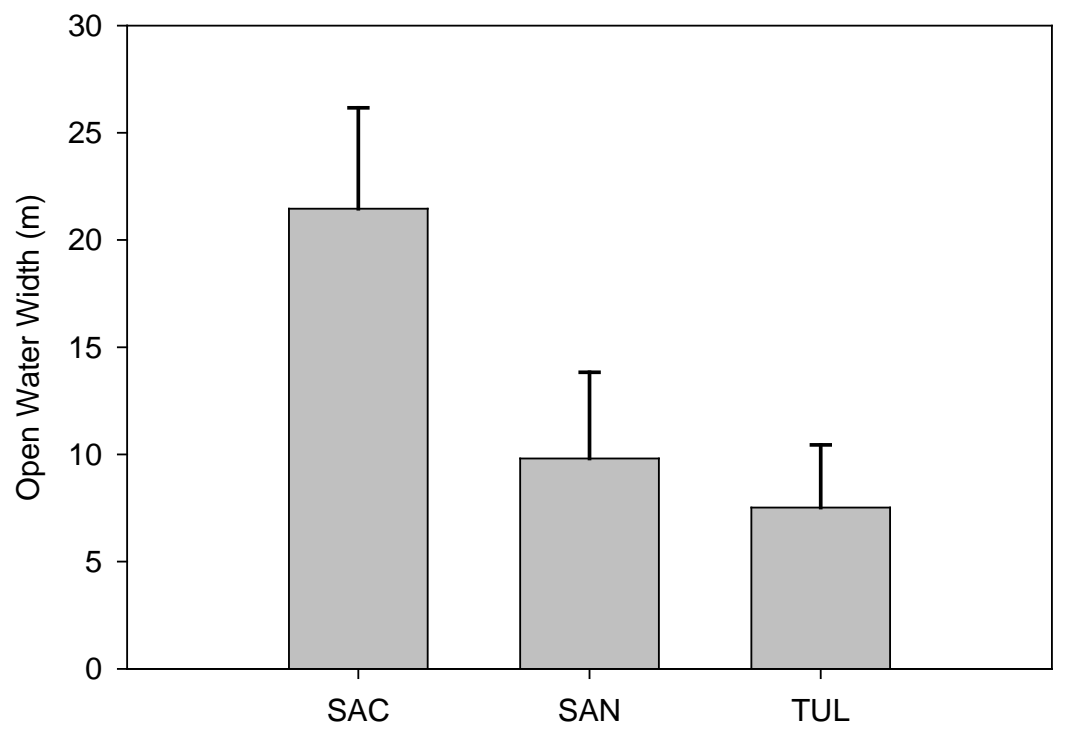

Figure A3. Average width $(\mathrm{m})$ of the open water zone by subbasin. $\mathrm{SAC}=$ Sacramento, $\mathrm{SAN}=\mathrm{San}$ Joaquin and TUL $=$ Tulare. Bars are standard errors.

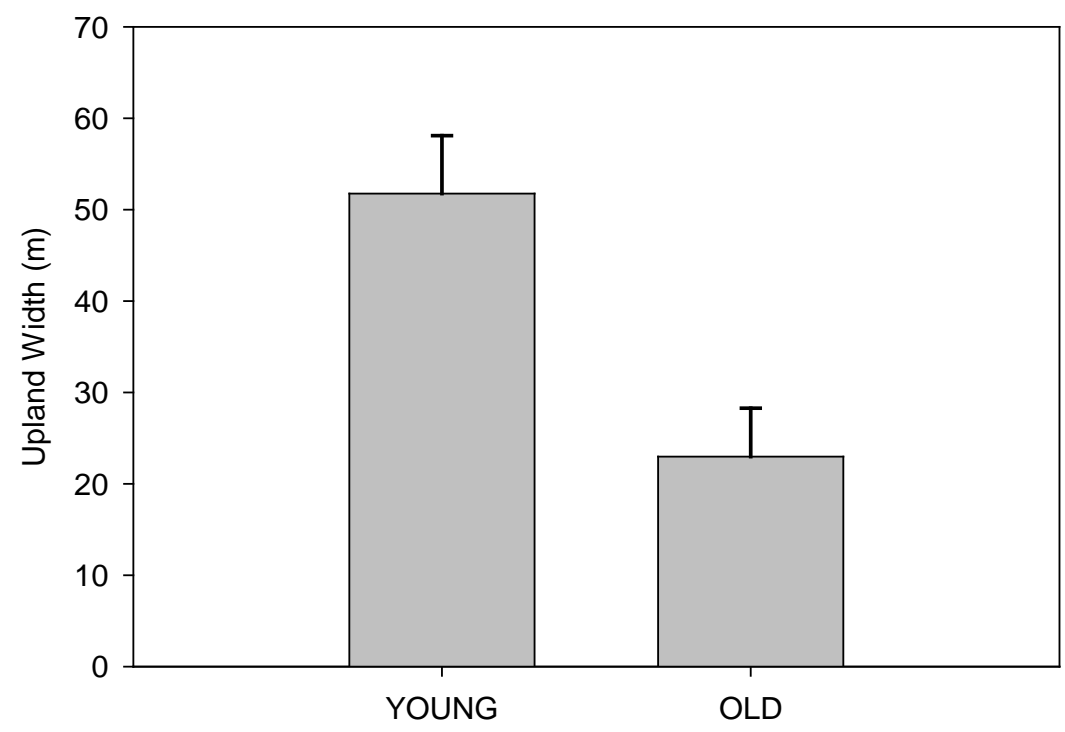

Figure A4. Average width $(\mathrm{m})$ of the upland zone by restoration age. Young sites are $\leq 5$ years since restoration; Old are $>5$ years. Bars are standard errors. 


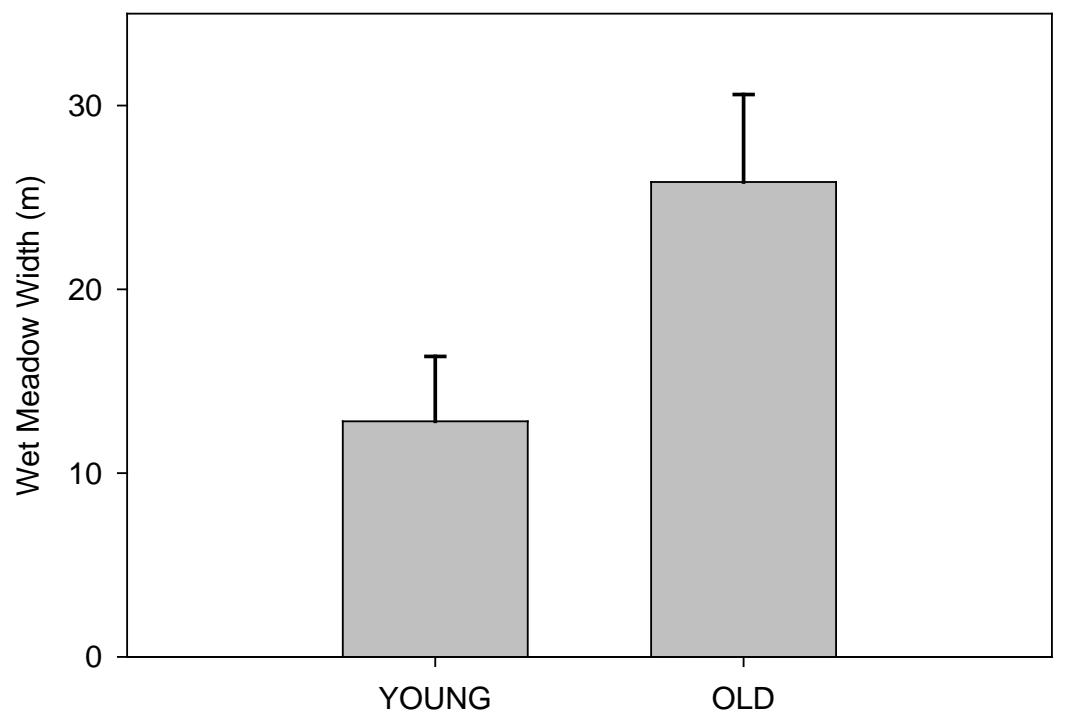

Figure A5. Average width $(\mathrm{m})$ of the wet meadow zone by restoration age. Young sites are $\leq 5$ years since restoration; Old are $>5$ years. Bars are standard errors.

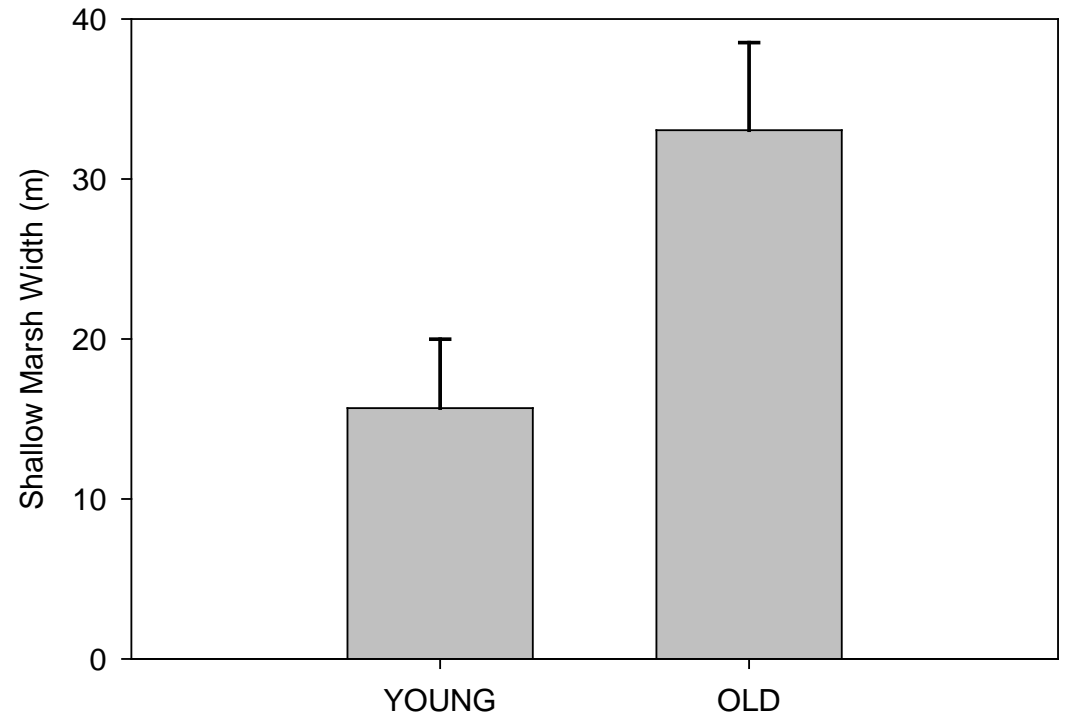

Figure A6. Average width $(\mathrm{m})$ of the shallow marsh zone by restoration age. Young sites are $\leq 5$ years since restoration; Old are $>5$ years. Bars are standard errors. 


\section{Discussion}

Hydrology is the single most important determinant of wetland ecosystem function. The presence, depth, and duration of water drives plant germination, influences floristic composition, water chemistry, and wildlife use (Euliss and others, 2004; Mitsch and Gosselink, 2007). In the CCV, WRP easement management is largely a function of access to water, with those in the drier southern portions experiencing the greatest shortfalls. Procurement of affordable and reliable water supplies limits the ability to manage restored easements as wetland habitat and may be the principle limiting factor determining ecosystem service delivery in the CCV.

The CCV was historically grassland, with 1.6-2.4 million ha of wetland habitat, now only about 81,000 ha of wetland remain. Most of these are privately managed and are threatened by population growth in urban areas, placing heavy demands on dwindling water supplies. Water from managed systems is becoming increasingly expensive and unreliable with increasing urban demands. In privately managed wetlands, semi-permanent and seasonal wetland area decreases from north to south and upland habitat (grassland and hay) is most abundant in the Sacramento subbasin and lowest in the San Joaquin subbasin (Central Valley Joint Venture 2006a). By comparison, we found a similar north-south trend in water availability on WRP, but significantly greater proportions of upland habitat in the Tulare subbasin. We attribute this primarily to the inability to access adequate water supplies to maintain seasonal and semi-permanent water on easements in the southern CCV.

Conditions in the drier Tulare subbasin, which relies heavily on pumped groundwater, are particularly dire. The Central Valley Joint Venture strategic plan (2006a) emphasized the need to make power supplies more affordable thereby ensuring reliable water. Initiatives, such as the Central Valley Project Improvement Act (CVPIA), which was passed in 1992, increased water reliability to the southern CCV. However, privately managed wetlands do not benefit directly from the CVPIA.

In the San Joaquin subbasin, many of the privately managed wetlands are located within the Grassland Resource Conservation District (GRCD), a 30,300 ha area, which contains 20 percent of the CCV's remaining wetlands. About 11,300 ha of the GRCD are protected from development, and are some of the most important wintering waterfowl areas in North America (California Association of Resource Conservation Districts, 2010).

Our assessments reveal that most WRP easements are managed as seasonal wetlands and are actively flooded on an annual basis. However, sites typically are flooded in the fall and early winter months as management is heavily geared towards providing habitat for wintering waterfowl. Historically, early migrants would have flown south to the Tulare subbasin in the late summer and early fall to take advantage of the large lakes and wetlands while the rest of the CCV was relatively dry. This would be followed by a northward migration to the San Joaquin and Sacramento subbasins as they flooded with winter rain and spring runoff. Given the unreliability of water, pre-irrigated cropland (outside of the growing season) in the Tulare subbasin was the only option provided to early fall migrants. Presently, only about 60 percent of sites in the Tulare subbasin are actively flooded in this manner as early season flooding is expensive for private landowners. This has resulted in a decline in early season use, particularly after the decrease in pre-irrigated cropland in the 1970s. 
Prior to agricultural and urban development, the Tulare subbasin contained about 150,000 ha of shallow lakes and seasonal wetlands. These included more than 100,000 ha of permanent and semi-permanent marshes (Werschkull and others, 1984). The loss of these marshes has had a strong impact on wetland dependent species, such as migratory waterfowl, that depended on the availability of wetland habitat upon return to the valley in the late summer and early fall. The majority of the regions lakes and Tule marshes were converted to agriculture by the mid-20th century. We found that easements in the Tulare subbasin exhibit larger proportions of upland habitat with management weighted towards upland species. We attribute the greater proportion of upland habitat in the WRPs of the Tulare subbasin to the large number of unmanaged and unrestored easements in that region. This is in contrast to a previous report indicating that more upland vegetation may be found in the northern CCV (Central Valley Joint Venture, 2006a). Upland areas may serve as waterfowl nesting and native pollinator habitat. Sites in the northern CCV tended to have more open water, probably due to greater water accessibility and the wetter climate.

Larger wet meadow zones in the Sacramento subbasin suggest an emphasis on moist soil management, which encourages the germination of annual seed bearing plants for wintering waterfowl. However, sites in the San Joaquin subbasin exhibited significantly smaller wet meadow zones despite their waterfowl focus. Wet meadow, shallow marsh and open water zones were better developed in older WRPs suggesting enhancements over time (that is, additional conservation practices, such as brood ponds) increase wetland habitat.

Less than one-half of all WRPs are not actively drawn down and therefore allow water to evaporate slowly. This strategy mimics historical conditions in the CCV, when slow evaporation of wetlands would occur over the summer following winter and spring flooding. This would have provided shallow ponds for breeding shorebirds.

We found that only one-half of the WRPs in the San Joaquin subbasin actively manage for shorebirds, despite being one of the most important wintering shorebird areas in North America. The Western Hemisphere Shorebird Reserve Network lists the Grasslands Ecological Area of the San Joaquin, a site of international importance, but management in the CCV is predominantly geared towards waterfowl, with water depths unsuitable for shorebird use. Furthermore, shorebirds in the CCV have become reliant upon sewage and evaporation ponds many of which are known to have concentrated heavy metals, such as selenium (Shuford and others, 1998).

Mowing, disking, and grazing may impact nutrient and carbon sequestration in plants and soils. Most actively managed sites are mowed and disked to control weeds and create open water areas for wintering waterfowl. On its own, flooding should encourage plant growth and therefore nutrient and carbon uptake; however, these services may be negated by increased disturbance and oxidation due to mowing, disking, and grazing activities.

Spraying for mosquitoes also may negatively impact invertebrate communities. Waterfowl typically increase intake of invertebrates in their diets in the late winter as they prepare to migrate back to breeding grounds. Interviews indicated that spraying to control mosquitoes is kept at a minimum in the Sacramento and San Joaquin subbasins, however, almost one-half the sites in the Tulare subbasin experienced spraying. 


\title{
Chapter B: Wetlands Reserve Program (WRP) Vegetation Biomass and Nutrient Content in the California's Central Valley (CCV)
}

\author{
By Sharon N. Kahara and Shannon Chapin, Humboldt State University
}

\section{Introduction}

Nutrient enrichment of aquatic ecosystems is a global problem that poses serious risks to both human health and biodiversity. Agricultural runoff is a major non-point source of nutrient enrichment. Intensively farmed cropland or ranch lands occupy more than 90 percent of the $\mathrm{CCV}$. Most of the cropland is irrigated and nutrient-rich non-point source runoff is a major concern.

Wetlands have increasingly been used as nutrient removal systems (Kadlec and Knight, 1996). Removal mechanisms include sedimentation, adsorption to sediments, denitrification, and plant uptake (Fisher and Acreman, 2004). Although nutrient uptake by plants can be significant, the proportion removed from high concentration systems is not considered a major removal mechanism for nitrogen and phosphorus.

Nonetheless, some commonly used wetland macrophytes in constructed wetlands designed to reduce nutrient loads include Typha, Cyperus, Scirpus, Juncus, and Sagittaria. Shallow marsh zones of WRPs in the CCV were usually composed of mixed stands of Typha and Scirpus. Emergent plants have large root and rhizome networks that extract nutrients from pore water. This process creates a gradient between the water column and the soil pore water thereby increasing nutrient retention (Reddy and others, 1999). Emergent vegetation of the shallow and deep marsh zones also tends to grow large, accumulating biomass.

Excessive inputs of nitrogen and phosphorus impair waterways causing increased blooms of cyanobacteria, algae, and submerged aquatic vegetation. Decomposition of vegetation and algal blooms can deplete dissolved oxygen concentrations resulting in fish kills and reducing biodiversity (Vitousek and others, 1997; Carpenter and others, 1998). Agriculture accounts for 47 percent of total annual phosphorus discharge to waterways in the United States (Allan and Castillo, 2007). Nitrogen sources include non-point sources and atmospheric deposition from fossil fuel combustion and volatilization from agricultural land and human waste.

Typically, wetland plants can remove about 4 percent of nitrogen and phosphorus, but may become a phosphorus source under long periods of inundation. Under low loading rates $\left(0.4-2.0 \mathrm{~g} \mathrm{~N} \mathrm{~m}^{-2} \mathrm{~d}^{-1}\right)$, plants have been reported to remove up to 30 percent of nitrogen, however, uptake declines significantly under higher loads (3.2-15.6 $\mathrm{g} \mathrm{N} \mathrm{m}^{-2} \mathrm{~d}^{-1}$ ) (Cronk and Fennessy, 2001). Long-term records collected from multiple stream gages in the CCV estimate median total nitrogen concentrations of $0.31 \mathrm{mg} \mathrm{L}^{-1}$ and median total phosphorus at $77 \mu \mathrm{L} \mathrm{L}^{-1}$ (U.S. Environmental Protection Agency, 2001).

\section{Carbon}

Wetlands have the highest carbon density of all terrestrial ecosystems, and have therefore attracted interest from policy makers as potential carbon sinks. The expansion of agriculture has played a major role in the release of greenhouse gases into the atmosphere as agricultural tillage practices typically increase plant decomposition and soil respiration (Schlesinger, 1984). 
USDA conservation programs are thought to reduce greenhouse gas emission by encouraging carbon sequestration, however, the potential sequestration by lands enrolled in WRP is unknown. Organic matter decomposition is often slower in wetlands due to lack of oxygen. However, anaerobic conditions often develop over time as a result of accumulated organic matter (Mitsch and Gosselink, 2007) and recently restored wetlands may sequester carbon differently than undisturbed wetlands. Furthermore, temperature, organic matter quality, hydraulic residence time, vegetation species, and maturity are among the factors that may influence carbon storage (Kayranli and others, 2010).

\section{Objectives}

Nutrient uptake and carbon storage by plants varies by species, season, age and latitude, and they may become nutrient sources as they age and die, or when parts of the plant slough off. Storage also is affected by factors including hydraulic retention time, climate and disturbance that can activate oxidation (Cronk and Fennessy, 2001). Therefore, climate, age and management practices likely may influence retention in the CCV and UKRB.

We evaluated the relative storage of nitrogen, phosphorus and carbon in standing vegetation as a function of restoration age, climate, and management intensity.

\section{Methods}

Samples were collected along four transects extending from the perimeter of each cell to the center. Transect measurements were limited to $100 \mathrm{~m}$ in WRP easements larger than $100 \mathrm{~m}^{2}$ and distances between transect locations were not fixed. Vegetation biomass was sampled by clipping all aboveground biomass (live and dead) from a $0.25-\mathrm{m}^{2}$ quadrat placed in the center of the $1-\mathrm{m}^{2}$ quadrat. Samples were weighed at the end of each collection day and returned to Humboldt State University for dry mass determination.

In 2008, dried samples were shipped to the Colorado State University Soil-Water-Plant Testing Laboratory. Total nitrogen (TN), total carbon (TC), and total phosphorus (TP) were determined following standard methods (Gavlak and others, 1994a, 1994b; Nelson and Sommers, 1996). In 2009, dried samples were shipped to the Agricultural and Natural Resources (ANR) Analytical Lab at University of California, Davis, for determination of total nitrogen (TN), total carbon (TC), and total phosphorus (TP) (Meyer and Keliher, 1992; Sah and Miller, 1992; Association of Analytical Communities, 1997).

\section{Results}

\section{Vegetation Biomass and Nutrients}

Vegetation biomass in the CCV decreased from north to south (fig. B1). Biomass was positively correlated with total precipitation in the winter months prior to collection (NovemberMarch; $\mathrm{R}^{2}=0.27, \mathrm{P}<0.05$, fig. $\left.\mathrm{B} 2\right)$ and inversely related to mean annual temperature $\left(\mathrm{R}^{2}=0.11\right.$, $\mathrm{P}<0.05$; fig. B3). Average nutrients in standing crops were $4.3 \mathrm{~g} \mathrm{~N} \mathrm{~m}^{-2}$ (range 0-11.7), $160.9 \mathrm{~g}$ $\mathrm{C} \mathrm{m}^{-2}$ (range 0-658.7) and $35.8 \mathrm{~g} \mathrm{P} \mathrm{m}^{-2}$ (range 0118.7). Amounts of vegetation nitrogen (VN), carbon (VC), and phosphorus (VP) varied significantly among subbasins $\left(\mathrm{F}_{2,66}=6.14, \mathrm{P}<0.001\right.$, $\mathrm{F}_{2,66}=8.79, \mathrm{P}<0.001$ and $\mathrm{F}_{2,66}=3.76, \mathrm{P}<0.001$, respectively). The greatest $\mathrm{VC}$ was in the Sacramento subbasin $\left(\mathrm{x}=214.19 \pm 25.08 \mathrm{~g} \mathrm{C} \mathrm{m}^{-2}\right)$ and decreasing south in both years (fig. B5). 
The San Joaquin subbasin had the highest VN and VP $\left(\mathrm{x}=6.23 \pm 0.99 \mathrm{~g} \mathrm{~N} \mathrm{~m}^{-2} \mathrm{x}=62.27 \pm\right.$ $10.56 \mathrm{~g} \mathrm{P} \mathrm{m}^{-2}$, figs. B4 and B6). Vegetation nutrients did not differ statistically along management and age treatments; however, $\mathrm{VN}$ on sites under intermediate and high management tended to be higher in older sites than in younger sites, VC tended to increase from younger to older sites, although VP decreased from younger to older sites.

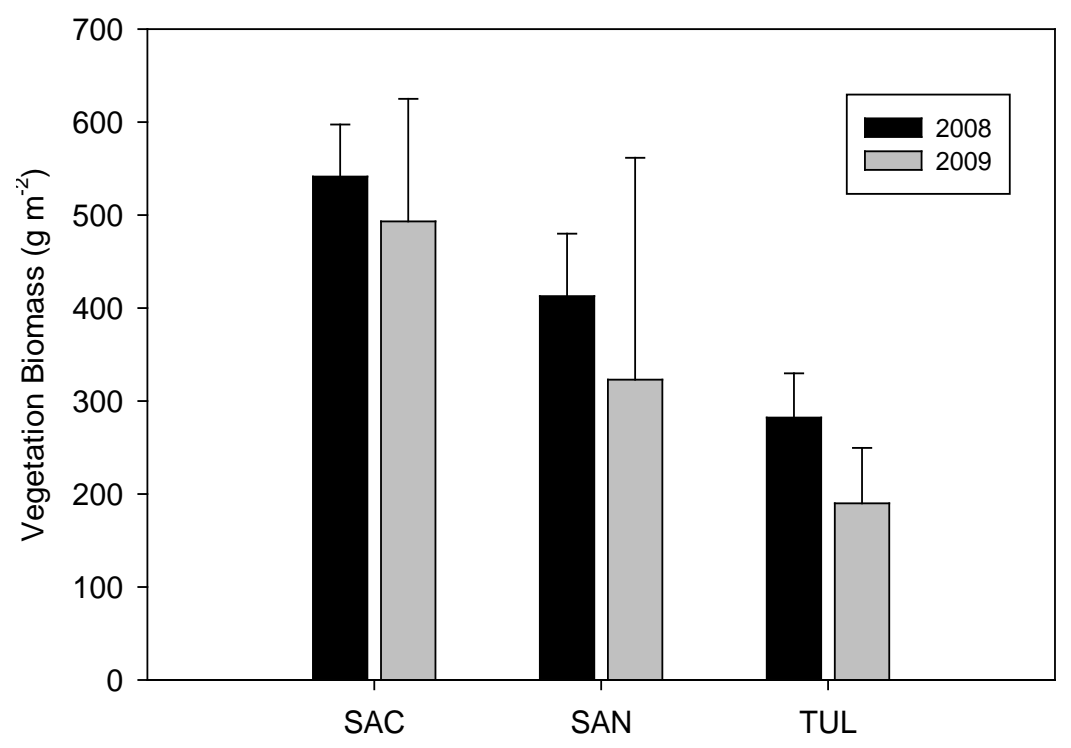

Figure B1. Average vegetation biomass $\left(\mathrm{g} \mathrm{m}^{-2}\right)$ by subbasin. SAC = Sacramento, SAN = San Joaquin and TUL $=$ Tulare. Standard error bars are shown.

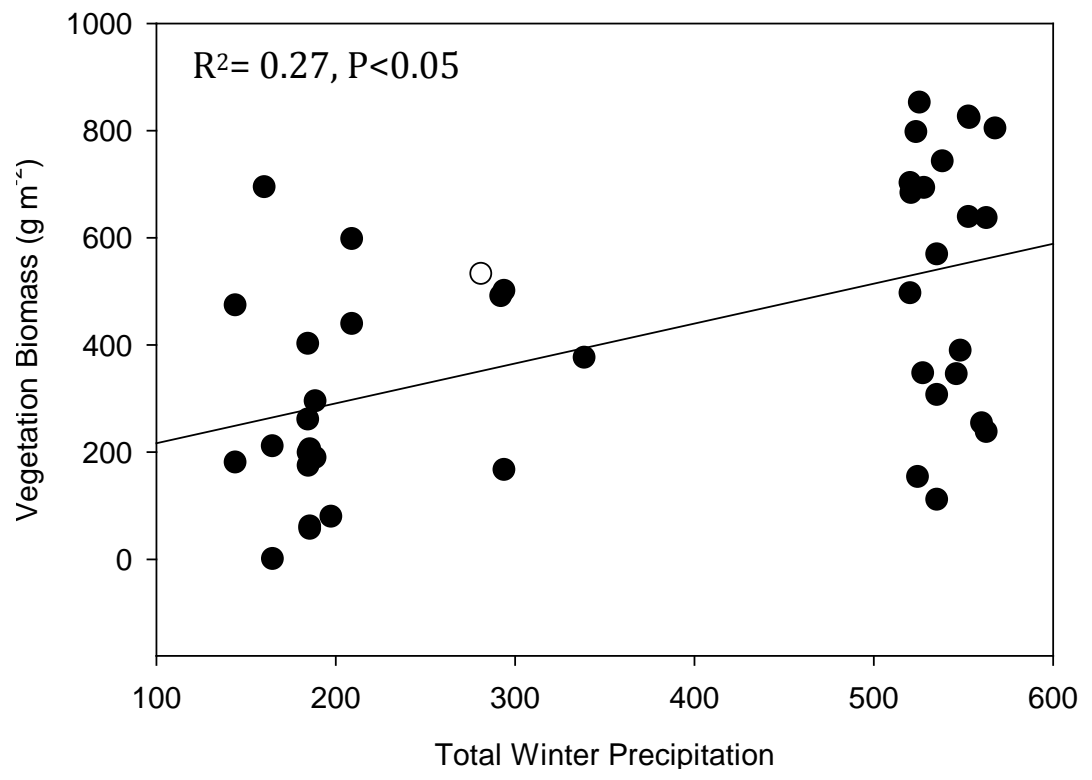

Figure B2. Average vegetation biomass ( $\mathrm{g} \mathrm{m}^{-2}$ ) versus total winter precipitation (November-March, $\mathrm{cm}$ ). 


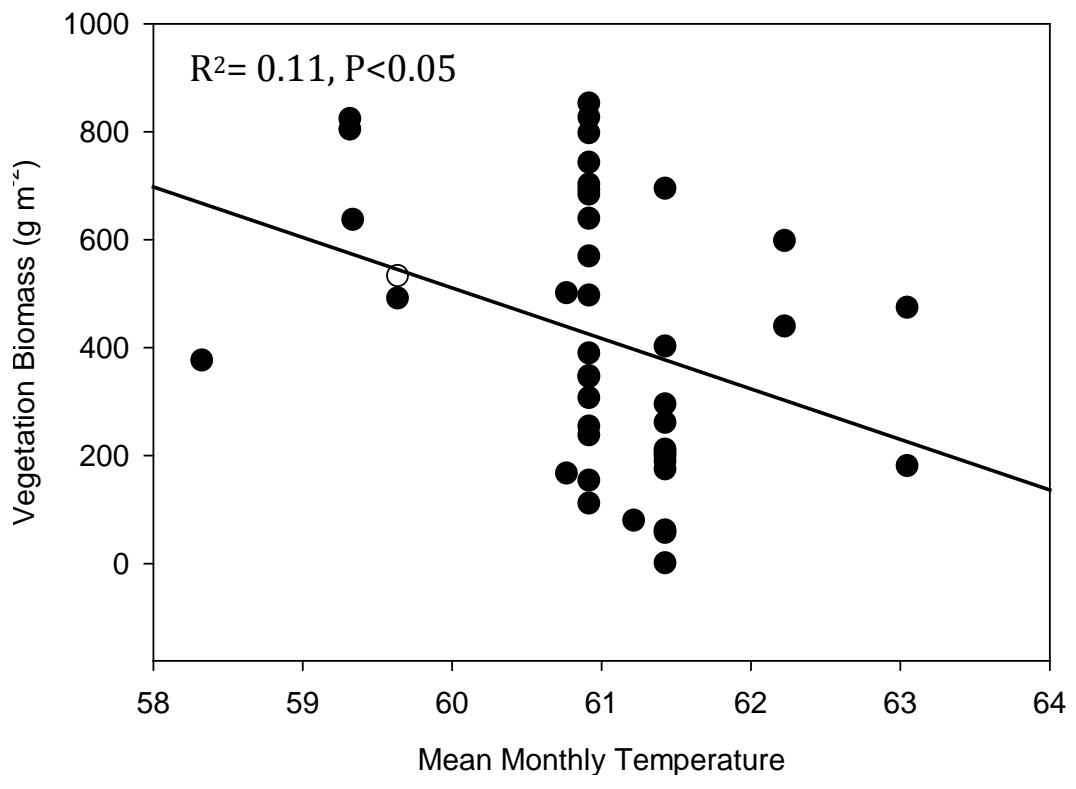

Figure B3. Average vegetation biomass $\left(\mathrm{g} \mathrm{m}^{-2}\right)$ versus mean monthly temperature $\left({ }^{\circ} \mathrm{C}\right)$.

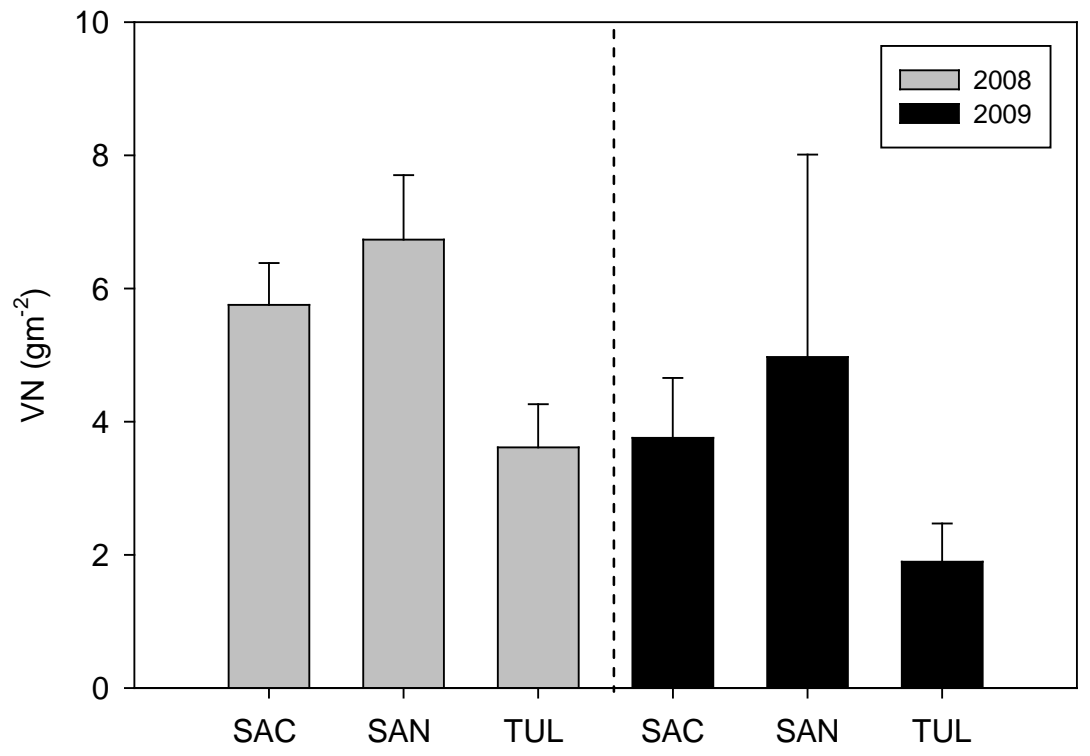

Figure B4. Vegetation nitrogen $(\mathrm{VN})$ in $\mathrm{g} \mathrm{m}^{-2}$ in shallow marsh vegetation by subbasin. $\mathrm{SAC}=$ Sacramento, SAN = San Joaquin and TUL = Tulare. Standard error bars are shown. 


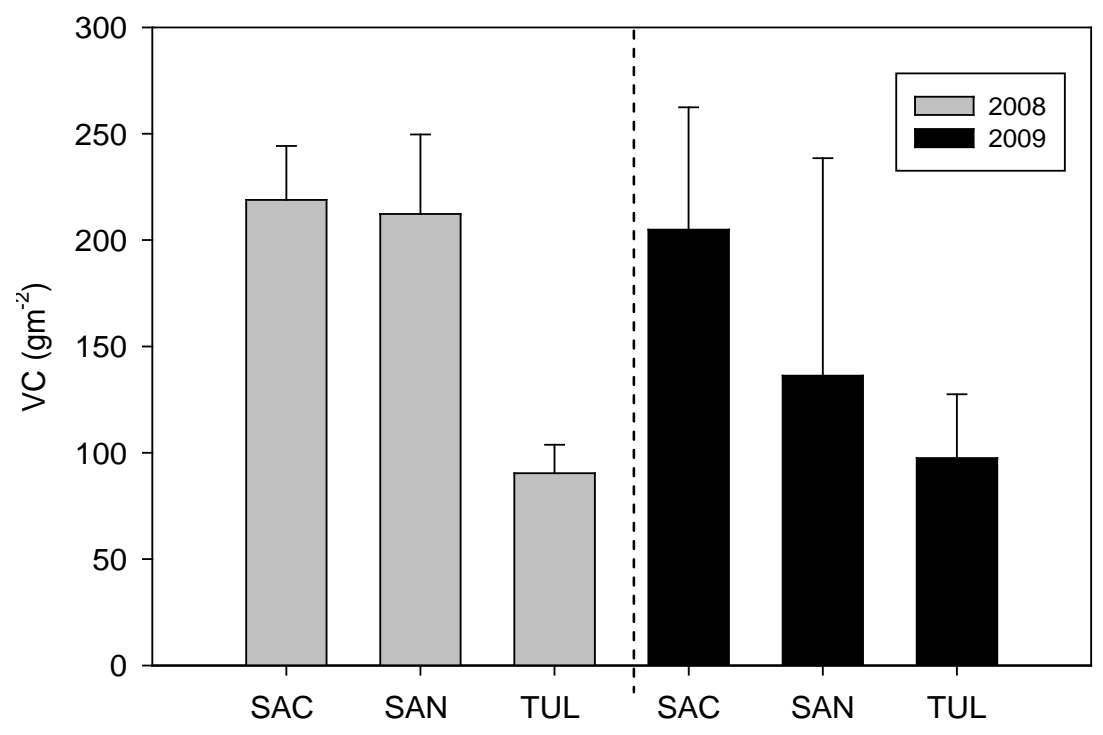

Figure B5. Vegetation carbon (VC) in $\mathrm{g} \mathrm{m}^{-2}$ in shallow marsh vegetation by subbasin. SAC = Sacramento, SAN = San Joaquin and TUL = Tulare. Standard error bars are shown.

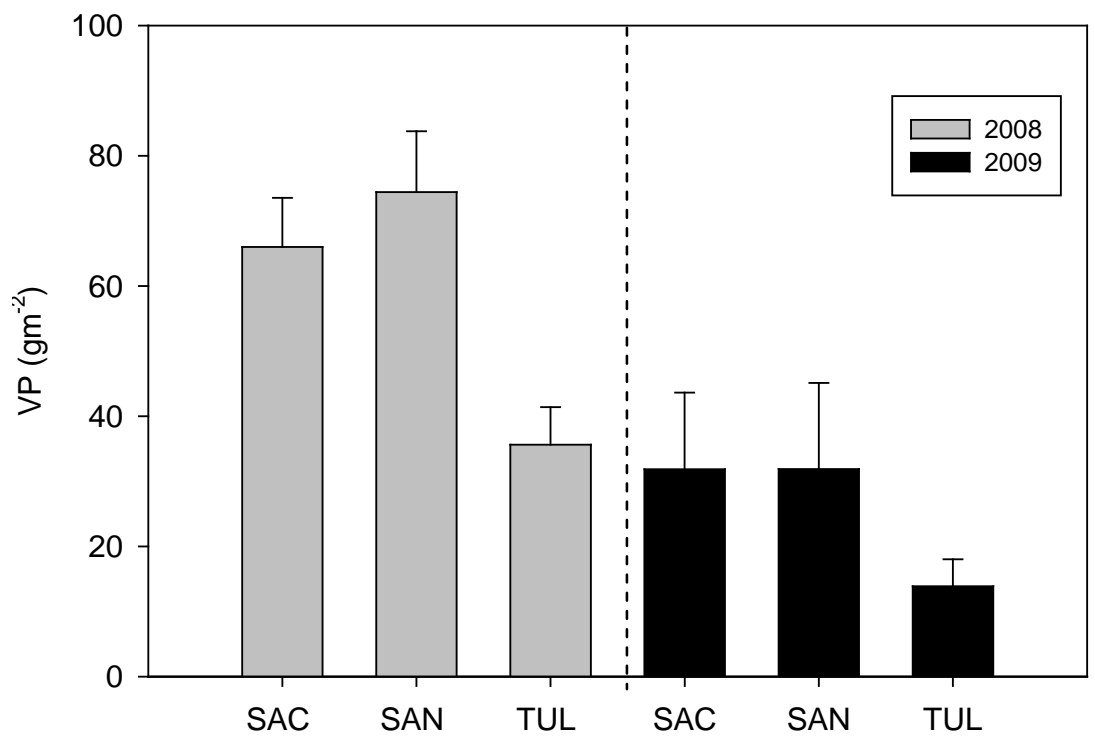

Figure B6. Vegetation phosphorus (VP) in $\mathrm{g} \mathrm{m}^{-2}$ in shallow marsh vegetation by subbasin. $\mathrm{SAC}=$ Sacramento, SAN = San Joaquin and TUL = Tulare. Standard error bars are shown. 
Vegetation nitrogen and phosphorus on inactively managed sites was lower in older sites than in younger sites, and vegetation carbon was higher in older sites than in younger sites (table B1). Vegetation nutrients were higher in intermediately managed sites than in younger sites.

Table B1. Percent difference in vegetation nutrient content among CCV-WRP sites classified as either young or old, and by management intensity.

[Management: Management intensity categories are defined in appendix I, table I3. "Low” refers to sites under low or no management; “Intermediate” refers to sites under intermediate management; "High” refers to actively managed sites]

\begin{tabular}{lrrr}
\hline \multirow{2}{*}{ Management } & \multicolumn{3}{c}{ Percent difference between young and old sites } \\
\cline { 2 - 4 } & TN & TC & TP \\
\hline Low & -12.03 & 37.08 & -22.56 \\
Intermediate & 9.74 & 67.63 & 30.38 \\
High & 6.51 & 1.77 & -8.64 \\
Average & 1.41 & 35.49 & -0.27 \\
\hline
\end{tabular}

Table B2. Estimated production of carbon in California's perennial crops compared to Wetlands Reserve Program easement shallow marsh vegetation.

[Maximum production rate of WRP is shown in parentheses (source: Kroodsma and Field, 2006)]

\begin{tabular}{lc}
\hline \multicolumn{1}{c}{ Crop type } & $\mathrm{g} \mathrm{C} \mathrm{m}^{-2} \mathrm{yr}^{-1}$ \\
\hline WRP shallow marsh & $13.4(54.8)$ \\
Vineyards & 30 \\
Oranges & 50 \\
Lemons & 60 \\
Walnuts & 100 \\
Plums & 100 \\
Almonds & 120 \\
Peaches & 130 \\
\hline
\end{tabular}




\section{Discussion}

Our data indicates that WRP easements in the CCV store between 3,928 and 356,177 metric tons of biomass in the shallow marsh zone alone. However, biomass may be lost as a result of intensive management practices such as mowing, seasonal drawdown of water, and disking. Biomass and carbon sequestration depend on plant species. The shallow marsh vegetation in WRP easements typically consisted of mixed stands of Typha spp., Scirpus spp., as well as other rush and sedge species, all of which vary considerably in mass and growth rates. Similarly, average carbon sequestration by agriculture in the CCV differs by crop type (Kroodsma and Field, 2006). Although net primary production by annual crops is high, complete removal at harvest, as well as tillage practices negate accumulated carbon. Perennial crops generally sequester more carbon than annual crops due to lower harvest indices and sequestration is lowest in non-rice annual cropland (Kroodsma and Field, 2006). Our data indicates that average above-ground carbon sequestered in the shallow marsh of WRP was comparable to the average sequestered by California's agricultural crops $\left(19 \mathrm{~g} \mathrm{C} \mathrm{m}^{-2} \mathrm{y}^{-1}\right)$ but lower than that of most perennial crops (table B2).

We found a strong positive relationship between precipitation, vegetation biomass, and carbon. This is likely due to higher precipitation received by the Sacramento subbasin, which is up to four times greater than the Tulare subbasin, where water accessibility to privately managed wetlands is limited.

\section{Nutrients}

Nutrient storage is affected by age and senescence can result in nutrient re-release. Our results indicate that although carbon storage may increase over time in inactively managed sites, the opposite was true for vegetation nitrogen and phosphorus that may decrease in time due to plant senescence and sloughing of dead material. Under intermediate and high management intensities, vegetation nitrogen content was greater in older sites than in younger sites. This increased nitrogen content may be due to various factors that we did not investigate, such as higher loading, growth of new vegetation following removal by mowing, or enhanced denitrification due to the presence of oxidized rhizospheres. Conversely, vegetation phosphorus appeared to decrease in older heavily managed sites, which may be the result of loading rates exceeding uptake or longer periods of inundation. These possibilities warrant further investigation.

Nutrient enrichment may arise from a number of sources, the major ones being fertilizer application to cropland and manure-rich runoff from cattle ranches. Most intensively irrigated cropland is found in the San Joaquin and Sacramento subbasins, which may explain higher nutrient content in the wetland vegetation in those regions. In cases of higher loading, plants take up more nutrients than they need to grow (luxury uptake) (Cronk and Fennessy, 2001).

The San Joaquin subbasin is extensively cultivated and has suffered severe deterioration in water quality as a result of increasing irrigation return flow and reuse of stream water. A 160km stretch of the San Joaquin River was declared a "water quality limited” zone (U.S.

Environmental Protection Agency, 2001). It is possible that higher nutrient loading in the more heavily cultivated croplands of the Sacramento and San Joaquin subbasins has resulted in higher observed nitrogen and phosphorus concentrations in wetland plants. We recommend comparison of nutrient uptake rates in future investigations of potential nutrient reduction provided by WRPs easements. 
This page left intentionally blank 


\title{
Chapter C: Wetlands Reserve Program (WRP) Soil Development in the California's Central Valley (CCV)
}

\author{
By Judith Z. Drexler, U.S. Geological Survey; Sharon N. Kahara, Humboldt State University, and Rosemary \\ M. Records, U.S. Geological Survey
}

\section{Introduction}

Wetland soil development involves structural and chemical changes in the soil matrix. The accumulation of organic matter is of critical importance to wetland soil development. Organic matter is required for cycling of nutrients, development of microbial communities, retention of moisture, and increasing friability of soil (Lal, 2002), all factors that are integral to a fully functioning wetland. Storage of organic matter in soils occurs when, over time, the rate of inputs from allochthonous sources and net primary production is greater than rate of decomposition and other losses such as erosion (Schlesinger, 1997). Because organic matter in soils contains approximately 50 percent organic carbon (Mitsch and Gosselink, 2007), soil storage of organic matter is an important process for storing or sequestering carbon, which today is of key interest as a means for mitigating carbon pollution.

The first step in initiating wetland soil development in restored wetlands is the establishment of necessary hydrologic conditions. Organic accumulation is enhanced in sites that have long periods of inundation that result in anaerobic conditions, and low decomposition rates (Collins and Kuehl, 2001). Many WRP easements also are routinely mowed and disked to maintain site accessibility and the preferred plant communities for waterfowl, while also reducing invasive species (Smith and others, 1995). Such practices have the potential to change the trajectory of organic soil formation by (1) replacing macrophytes, such as Schoenoplectus and Typha (which are major litter contributors and whose roots are integral for peat formation) with desired annual species (Smith and others, 1995), and (2) reducing or even preventing accumulation of organic material by physically breaking up developing soil (Larney and others, 1997; Saggar and others, 2001). Although such hydrologic manipulation may disturb the natural progression of wetland soil development, few data exist to test this hypothesis.

Wetlands also are potential nitrogen and phosphorus sinks and may reduce nutrient loading to aquatic environments. Phosphorus storage depends on a number of factors including plant and microbial uptake, soil adsorption, incorporation into peat and the presence of iron and aluminum minerals. Nitrogen exists in various organic and inorganic forms in wetlands and removal is largely mediated by microbial activity (Mitsch and Gosselink, 2007).

The purpose of this study was to determine the trajectory of percent soil organic carbon, nitrogen, and phosphorus through time given the hydrologic manipulations used to maximize wildlife habitat. We studied 35 restored wetland sites distributed throughout the CCV of California, five of which are located in national wildlife refuges. The remaining 30 sites are a subset of WRP wetlands being studied in the CCV as part of the USDA-NRCS Conservation Effects and Assessment Program (CEAP), a national assessment with the goal of determining the ecosystem services provided by wetlands in the WRPs (U.S. Department of Agriculture, 2006). 


\section{Methods}

Soil sampling included digging 30-40 cm soil pits and collecting 15-cm deep soil cores at 35 sites in the CCV during both 2008 and 2009 (appendix II, table II-1). The following soil parameters were measured: the depth of the organic horizon, the depth of the plant litter layer, total carbon, total nitrogen, calcium carbonate $\left(\mathrm{CaCO}_{3}\right)$, total phosphorus, and bulk density. In the laboratory, all samples were weighed, dried at $101^{\circ} \mathrm{C}$ to a constant weight, and then reweighed for bulk density determination.

In 2008, soil samples were analyzed by the Colorado State University Soil, Water, and Plant Testing Laboratory in Fort Collins, Colorado. Samples were analyzed for total C and N using the methods outlined in Bremner (1996) and Nelson and Sommers (1996). Total P was analyzed by acid dissolution followed by Inductively Coupled Plasma Atomic Emission Spectrometry (ICP) (Kuo, 1996). Calcium carbonate was determined according to the methods in U.S. Department of Agriculture (1996).

In 2009 following drying, samples were analyzed by the Agriculture and Natural Resources Laboratory of the University of California at Davis, California. Analysis of total N and total C was conducted according to methods in Association of Analytical Communities (1997). Total P was analyzed by acid dissolution followed by ICP analysis (Sah and Miller, 1992). Gravimetric determination of $\mathrm{CaCO}_{3}$ was carried out according to the methods in U.S. Department of Agriculture (1954). All soil samples were ground and sieved through a 2-mm sieve before analysis. The three management intensity categories for survey sites are defined in appendix I, table I3.

\section{Statistical Analysis}

Percent organic carbon, bulk density, percent total nitrogen, percent total phosphorus, mean litter layer, and mean O-horizon of soil samples collected during 2008 and 2009 were analyzed by two-way ANOVA across both management category and age class (using two different age class designations: $(1) \leq 5$ years since restoration, and (2) or $>5$ years since restoration. Simple linear regressions also were performed between each variable and years since restoration. All variables were square-root transformed except litter, which was ln-transformed and O-horizon, which was $\log _{10}$-transformed, to approximate normality. Statistical analyses were performed using SYSTAT Version 12 (SYSTAT, 2007).

\section{Results}

Among the soils characteristics, the most variable parameters were the depth of the Ohorizon, which ranged from 0 to $17.5 \mathrm{~cm}$, and the litter layer, which ranged from 0 to $9.7 \mathrm{~cm}$ (table C1). Percent organic carbon ranged between 0.6 and 3.8 percent (fig. C1). Overall, the restored wetland sites had bulk densities of approximately $1 \mathrm{~g} \mathrm{~cm}^{-3}$ and total percent $\mathrm{N}$ and $\mathrm{P}$ well below 1 percent.

A two-way analysis of variance for each soil characteristic by management category and age class (using two different age class designations (1) $\geq$ or $<5$ years since restoration, and (2) $\geq$ or $<10$ years since restoration) showed no significant results for any factor or any interaction term at $\mathrm{P}<0.05$. Linear regressions between each soil variable and years since restoration also showed no significant results. 


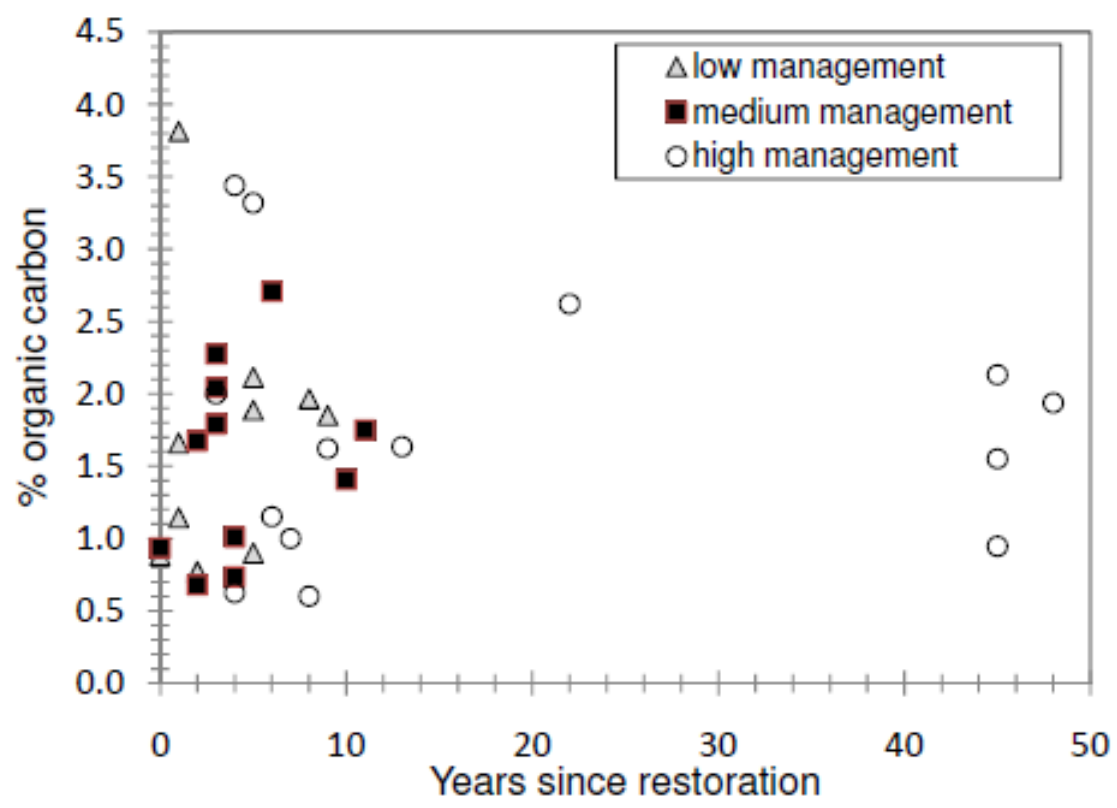

Figure C1. Percent organic carbon versus years since restoration.

Table C1. Soil characteristics of restored WRP easement wetlands in the CCV ( $n=35)$.

\begin{tabular}{lccccccc}
\hline & $\begin{array}{c}\text { Litter layer } \\
(\mathbf{c m})\end{array}$ & $\begin{array}{c}\text { Organic } \\
\text { layer }(\mathbf{c m})\end{array}$ & $\begin{array}{c}\text { percent } \\
\text { Organic } \\
\text { carbon }\end{array}$ & $\begin{array}{c}\text { Bulk } \\
\text { density } \\
\left(\mathbf{g ~ c m}^{-3}\right)\end{array}$ & $\begin{array}{c}\text { Organic carbon } \\
\text { density } \\
\left(\mathbf{g ~ c m}^{-3}\right)\end{array}$ & $\begin{array}{c}\text { Total } \\
\text { percent } \\
\mathbf{N}\end{array}$ & $\begin{array}{c}\text { Total percent } \\
\mathbf{P}\end{array}$ \\
\hline Mean & 1.63 & 5.72 & 1.67 & 1.02 & 0.016 & 0.151 & 0.058 \\
Range & $0-9.7$ & $0-17.50$ & $0.6-3.81$ & $0.31-1.45$ & $0.005-0.035$ & $0.026-$ & $0.005-0.115$ \\
& & & & & & 0.272 & \\
Standard & 0.35 & 0.94 & 0.14 & 0.04 & 0.001 & 0.011 & 0.005 \\
error & & & & & & & \\
Median & 1 & 4.4 & 1.66 & 0.994 & 0.015 & 0.148 & 0.053 \\
\hline
\end{tabular}




\section{Discussion}

All restored seasonal and semi-permanent wetlands in this study contain mineral soils with low percent organic carbon content that has not increased through time (fig. C1). Because of this, other changes usually associated with organic matter accumulation such as nutrient increases and bulk density decreases also have not occurred (Bishel-Machung and others, 1996; Ballantine and Schneider, 2009). None of the variance in any soil characteristic could be explained by the management intensity at the sites or time since restoration because none of the statistical analyses was significant. These results suggest that there is another factor that controls organic matter accumulation besides management intensity and time since restoration.

We postulate that organic carbon accumulation is low in restored CCV wetlands because annual seasonal drawdown spurs aerobic decomposition of most of the accumulated organic matter. We arrived at this overall conclusion because our results show that, even after more than 40 years, organic carbon accumulation is low in these managed wetlands (fig. C1). Both seasonal and semi-permanent wetlands are drawn down either in spring or summer, which permits long, uninterrupted periods of drying during the hot, dry season from May through October. Under hot, drying conditions, microbial decomposition flourishes in the moist soils, precluding significant accumulation of organic matter. In addition, cycles of soil saturation followed by drying appear to further stimulate the decomposition of organic matter in wetland soils (Collins and Kuehl, 2001).

The distinct lack of organic carbon, nitrogen, and phosphorus accumulation with time indicates that, under current management regimes, restored seasonal and semi-permanent wetlands in the CCV do not have high potential for mass sequestration of carbon or nutrient pollution as do other wetland types such as the prairie potholes in the Midwestern United States (Euliss, Jr. and others, 2006). Whether or not some of the CCV sites could be better managed to sequester organic matter requires further study. Future work focused on the individual impacts of specific management activities focusing on hydrological applications as well as the range of within-site variability would be very helpful in better understanding organic carbon accumulation in these restored wetlands. 


\section{Chapter D: Soil Loss Reduction by Wetland Reserve Program (WRP) in California's Central Valley (CCV)}

By Sharon N. Kahara, Humboldt State University, and Rosemary M. Records, U.S. Geological Survey

\section{Introduction}

Soil erosion is a pervasive problem in the CCV and often results in reduced productivity. It is estimated that soil erosion costs the United States up to $\$ 20$ billion in annual losses. About 60 percent of water eroded soils contributes to pollution of streams and rivers. This soil can transport excessive levels of nutrients, increases turbidity, and threatens drinking water supplies and aquatic biota. Eleven water body segments in the CCV are listed as impaired under the draft Clean Water Act due to sediment toxicity from agriculture (Long and others, 2010). We evaluated the potential of WRP to reduce soil loss under three possible cropland erosion scenarios and the potential of WRPs for reducing sediment loading to streams in the CCV.

\section{Methods}

We estimated change in soil erosion since the establishment of WRP in the CCV under three scenarios using Environmental Protection Agency (EPA) Arc Macro Language (AML) scripts in ArcGIS 9.3 (R. Van Remortel, Lockheed Martin Corp, written commun., September 8, 2009). These scripts model watershed soil sheet and rill erosion on a cell-by-cell basis and summarized by watershed (subbasins layer, U.S. Geological Survey Water Resources Discipline and U.S. Department of Agricultural Natural Resources Conservation Service, undated ) based on the Revised Universal Soil Loss Equation (RUSLE), $A=R^{*} K^{*} L S^{*} C * P$, where:

A = estimated average annual soil loss per unit area caused by rainfall,

$\mathrm{R}=$ climatic erosivity factor (erosion force of rainfall as determined by kinetic energy and 30 min intensity),

$\mathrm{K}=$ soil erodibility factor (susceptibility of soil to erosion and rate of runoff),

$\mathrm{L}$ and $\mathrm{S}=$ combined slope length and steepness factor,

$\mathrm{C}=$ cover management factor (effect of plants, soil cover, soil biomass and soil disturbance activities on erosion), and

$\mathrm{P}=$ supporting practice factor (impact of supporting practices on erosion rate). 
$\mathrm{R}$ and $\mathrm{K}$ factors were supplied by the U.S. Environmental Protection Agency (EPA) from standard datasets (PRISM climate group, State Soil Geographic Databases). The LS factor was computed from ArcHydro-processed National Elevation Dataset 30-m mosaicked rasters. The P factor was assigned a value of one in all CEAP RUSLE models (R. Van Remortel, Lockheed Martin Corp, written commun., September 8, 2009). The $C$ factors were assigned to National Land Cover Dataset (NLCD) 2001 landcover types based on Smithsonian Environmental Research Center NLCD 1992 values, with cultivated cropland areas set at either low (0.01), medium (0.205), or high (0.4) (Homer and others, 2004; Boomer and others, 2008; Boomer, K., Smithsonian Environmental Research Center, written commun., August 14, 2009; appendix IV). Soil loss was modeled for two restoration scenarios: (1) "before” WRP restoration, with all WRP easements treated as cultivated cropland, and (2) "after" WRP restoration, with all WRP easements treated as wetlands. We estimated reductions in soil loss through WRP implementation by comparing loss rates prior to WRP, represented by a modified National Land Cover Dataset (NLCD, 2001 layer). To achieve this, WRP boundaries were overlain on the original NLCD 2001 layer and assigned a cropland classification (NLCD 2001 code of 82) and corresponding $C$ factor values. The latter scenario was represented by the same NLCD 2001 layer, but updated with present-day WRP easement acreages and locations in which WRP were assigned a NLCD 2001 land cover classification of emergent herbaceous wetlands (NLCD 2001 code of 95). Because of the variability of cropland soil loss rates reported in literature, soil loss at the watershed level was modeled under three cropland erosion rates: low, medium, and high.

The RUSLE model has been widely used to estimate average annual soil loss per unit area by surface runoff. The model may be used to estimate the effects of specific cropping systems, management strategies, and erosion control practices on average annual erosion. The purpose of our applying the model to CCV WRP easements was not to achieve factual accuracy, but rather to demonstrate the potential impact of USDA programs in the study area.

We applied a soil loss modeling procedure to estimate watershed level soil loss in GIS, Soil and Landform Metrics (SLM). The computer algorithm generates grids for each component used to calculate the RUSLE. Reliable estimates of slope length, current land use, cropping history, and erosion control are dependent on spatial and temporal resolution of the input data, the method provides an opportunity to examine effects at large scales that would otherwise be logistically difficult. Calibration and validation were not conducted. The SLM represents average, long-term conditions and sediment yields, and does not currently have the capacity to be calibrated and validated, as do other spatial models such as the Soil and Water Assessment Tool (SWAT). However, preliminary comparisons of the SLM to SWAT in Louisiana's Tensas basin indicate that average annual sediment yield predictions from calibrated and validated SWAT models simulate sediment losses at the basin outlet and display trends across the watershed very similar to the SLMs' predictions for much of the watershed, although the RUSLE model may overestimate sediment loading in riparian areas (J. Quansah, Tuskegee University, written commun., October 12, 2009). Although this relationship has yet to be evaluated for other watersheds, it appears that the SLM is capable of providing an efficient and accurate assessment of long-term soil loss for at least some watershed types. 


\section{Results and Discussion}

We estimated reductions in soil loss through conversion of cultivated cropland and grazing land to WRP at the current locations within the watershed level under three cropland erosion rates: low, medium and high. Overall, percent declines in soil loss were found to be very low even under higher predicted rates of soil erosion. This is likely due to the flat terrain of the CCV. In addition, one of the limitations of the use of the GIS-RUSLE models at regional scales is the difficulty in obtaining accurate slope length factors, which in this case are generated from a Digital Elevation Model (DEM). Changes in the terrain occurring at scales smaller than the DEM cell sizes, for example furrow irrigation, may not be captured in the data set.

On average, our analysis suggests that soil losses across the CCV have decreased by 0.04 , 2.44, and $4.58 \mathrm{~kg} \mathrm{~m}^{-2} \mathrm{yr}^{-1}$ under low, medium, or high cropland erosion rates, respectively, since the establishment of WRP. Under low cropland erosion rates, soil loss in the CCV could be reduced by 0.7 percent, medium cropland erosion by 8.1 percent, and high cropland erosion by 10 percent. These results suggest that establishment of WRP could potentially reduce overall soil loss in the CCV by 1, 55 or $103 \mathrm{~kg} \mathrm{~m}^{-1} \mathrm{yr}^{-1}$ under low, medium, or high cropland erosion rates scenarios, respectively.

Impact of WRP on mitigating soil loss was greatest in the northern CCV and Lower Cosumnes-Lower Mokelumne watershed under all three scenarios (figs. D1, D2, and D3). This may be due to the relatively larger change in the RUSLE C factor, which represents cover management in the Lower Cosumnes/Mokelumne drainage basin relative to other drainage basins. In addition, the relative proportion of WRP acreage restored in the Lower CosumnesLower Mokelumne drainage basin was fairly large compared to other drainage basins.

Due to the construction design of typical WRP properties, in which wetland cells (management units) are divided by 1-2 m high levees, and the highly managed, leveed waterways of the CCV, WRP do not generally function like hydrologically connected riparian wetlands (fig. 4). Although WRPs may accrete sediment from waterways through managed flooding and irrigation and occasional flood events, these wetlands are geomorphologically isolated from fluvial processes of scour and deposition that shaped historical riparian wetlands.

Easement acres enrolled under WRP and other USDA programs are assumed to accrue soil loss reductions over time such that time since restoration may greatly increase reduction benefits. We recommend further assessment of WRP impacts on soil loss reductions to determine the point at which benefits would be sufficient to positively impact aquatic habitats. 


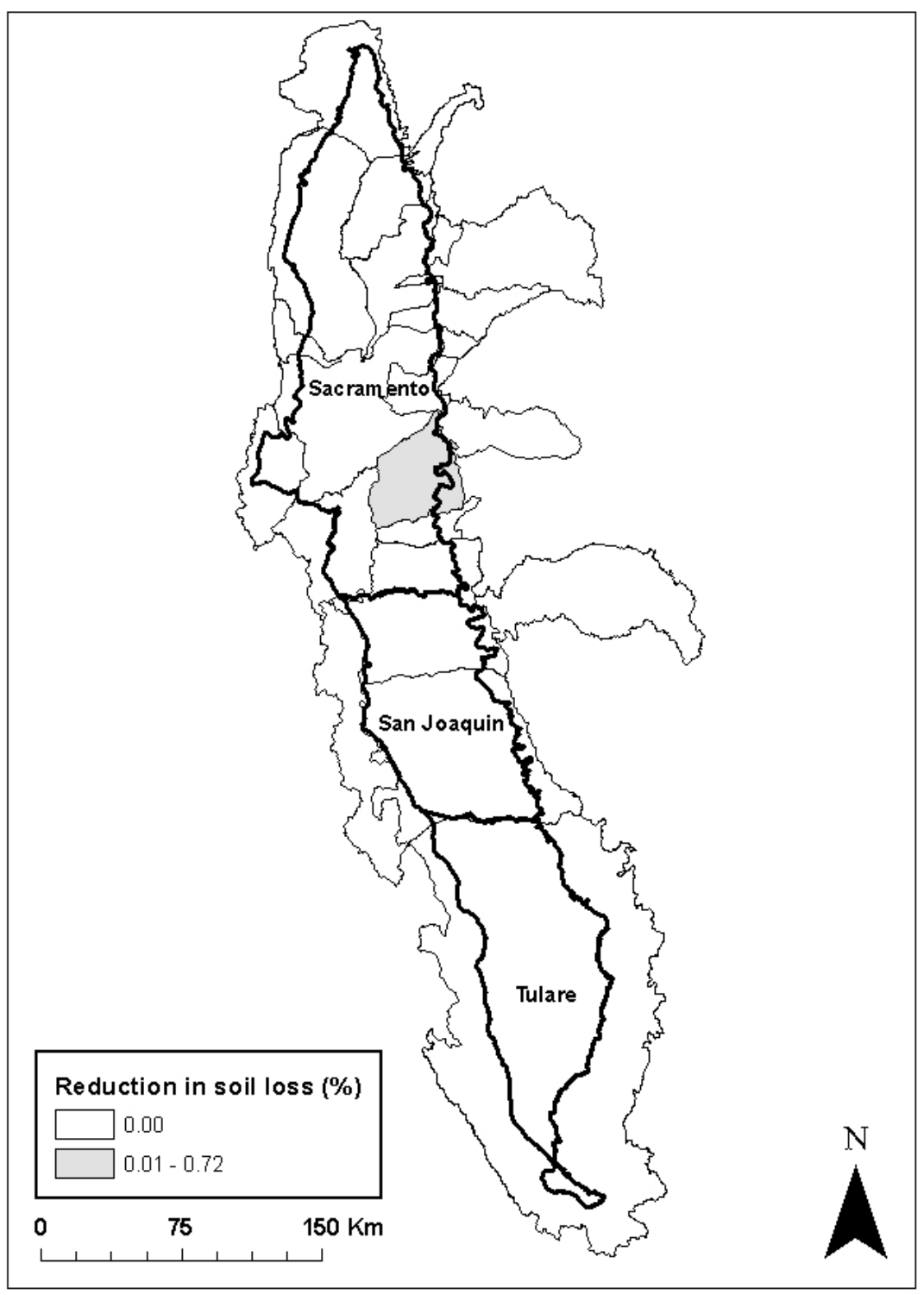

Figure D1. Percent reduction in soil loss in CCV watersheds through conversion of crop and grazing lands to WRP under low cropland erosion rates. CCV subbasins are outlined in bold and watersheds (HUC-8) outlined in dark gray (Central Valley Joint Venture, 2006b, shapefile format). 


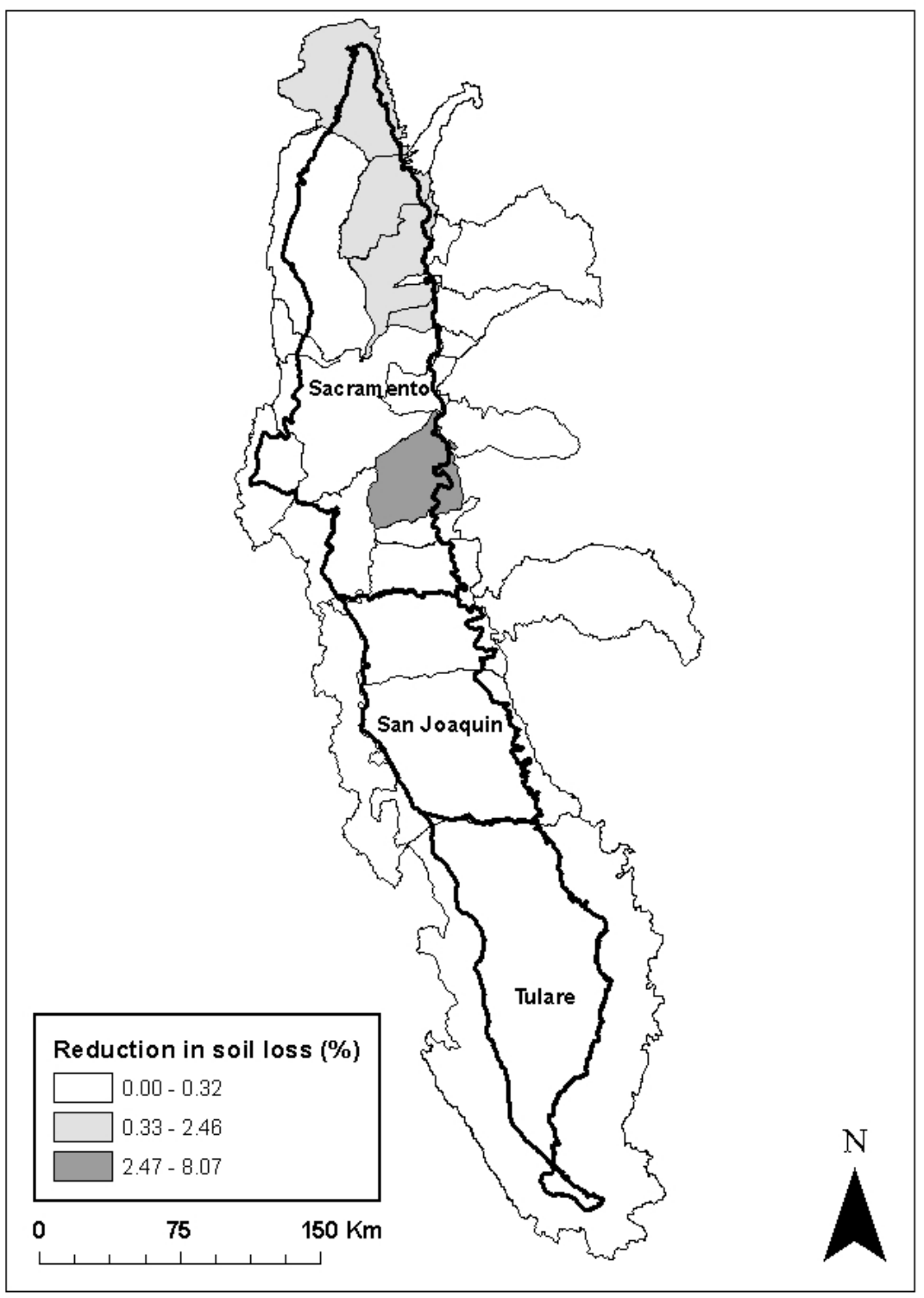

Figure D2. Percent reduction in soil loss in CCV watersheds through conversion of crop and grazing lands to WRP under medium cropland erosion rates (Central Valley Joint Venture, 2006b, shapefile format). 


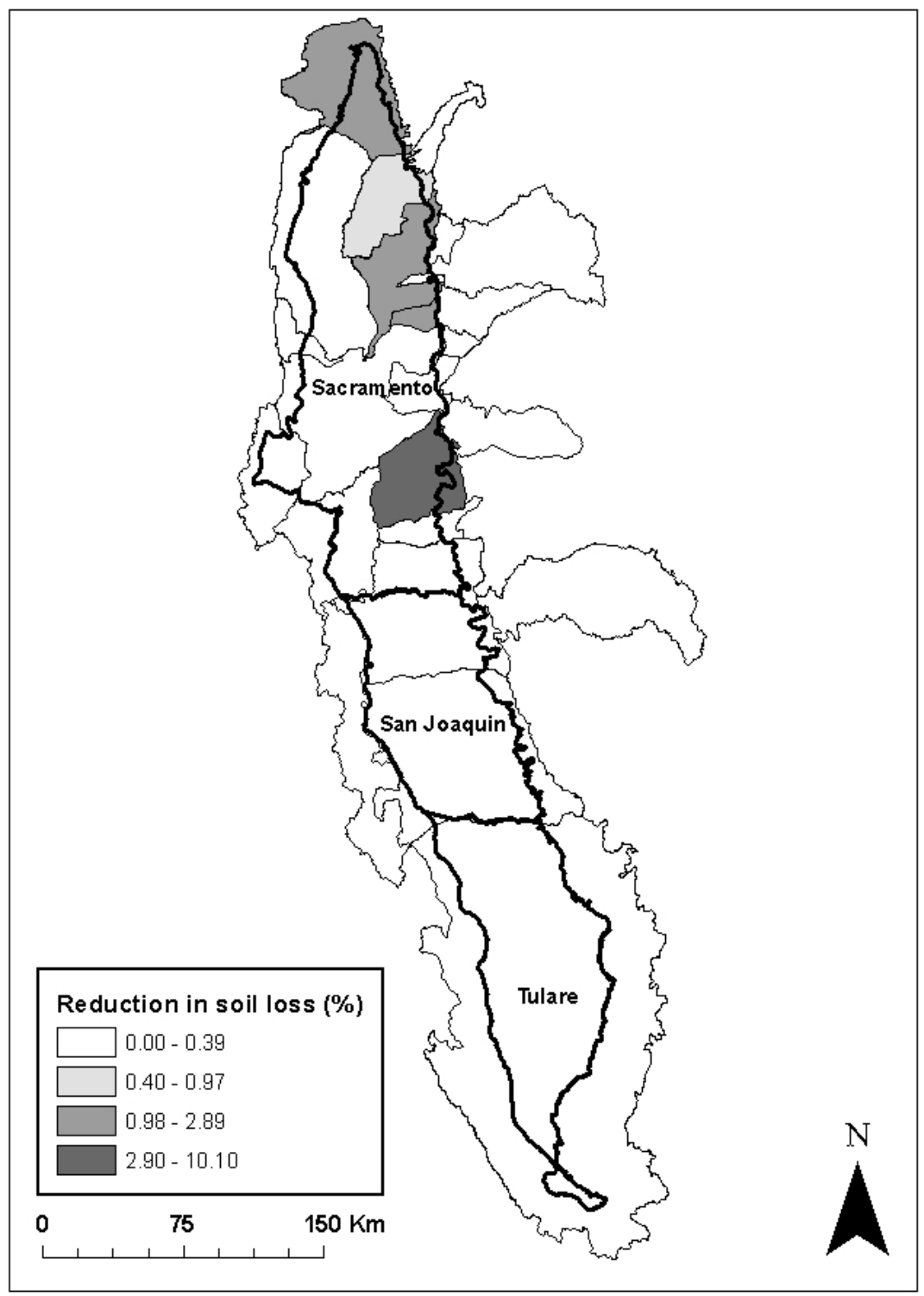

Figure D3. Percent reduction in soil loss in CCV watersheds through conversion of crop and grazing lands to WRP under high cropland erosion rates (Central Valley Joint Venture, 2006b, shapefile format). 


\title{
Chapter E: Floodwater Storage Capacity of Wetland Reserve Program (WRP) in the California's Central Valley (CCV)
}

\author{
By Sharon N. Kahara, Humboldt State University; Rosemary M. Records, U.S. Geological Survey; and \\ Shannon J. Chapin, Humboldt State University
}

\section{Introduction}

Floodwater attenuation is an important service performed by wetlands. Much of the CCV is prone to flooding, particularly in the southern portion, which formerly held large freshwater lakes and wetlands. Although these lakes no longer exist, the current topography makes the Tulare subbasin highly susceptible to flooding in high precipitation years. Portions of the Sacramento/San Joaquin River delta include tracts that lie below sea level. Major floods in 1997 resulted in extended damage and in 2004, levee failure led to inundation of 4,800 ha of farmland with more than 197 million $\mathrm{m}^{3}$ of water (California Department of Water Resources, 2005).

The current flood control system in the CCV includes about 2,575 km of state and federal levees as well as thousands of privately maintained levees. Many of these levees were constructed along the edges of the Sacramento and San Joaquin Rivers and as a result retain remnants of the historical riparian forest (California Department of Water Resources, 2005). This vegetation provides important habitat to a variety of threatened and endangered species including Delta smelt (Hypomesus transpacificus), Central Valley Chinook salmon (Oncorhynchus tshawytscha), Swainson's hawks (Buteo swainsoni) and burrowing owls (Athene cunicularia). Levees of the CCV face problems such as lack of engineering, old age, lack of maintenance, and animal burrowing. These factors combine with increased development in floodplains to increase flood hazard in widespread areas.

Restored wetlands within sensitive flood-prone areas may provide some protection against flooding. Our objective was to compare estimates of potential floodwater storage capacity of WRP easements in the CCV. Unlike natural wetlands, WRP easements in the CCV are heavily modified basins, designed to optimize the flow and retention of water to and from the CCVs extensive system of canals and water delivery channels (fig. 4). Assuming uniform bathymetry, potential storage volume could be estimated by quantifying the product of surface area and flood depth. The only limiting factors in this case would be outlet height. However, many easements also include topographical features such as swales and ponds, which may increase storage capacity. Our goal in this section was to quantify potential storage of water each site at multiple depths using a simple volumetric analysis and to compare this with field measurements. Field measurements were conducted at 44 sites to acquire more accurate bathymetry estimates and estimate error margins to be expected from using the first method. 


\section{Methods}

We conducted a methodological comparison of potential floodwater storage using two methods of GIS estimated storage that is, (1) a volumetric estimate using delineated cell parameters and (2) on-site estimates using measurements collected in the field.

\section{Method 1: Volumetric Estimate Using Delineated Cell Perimeters}

We delineated WRP easement perimeters and cells in ArcMap (Version 9.3) using National Agriculture Imagery Program photographs (NAD 1983 UTM Zones $10 \mathrm{~N}$ and $11 \mathrm{~N}$, $1 \mathrm{~m}, 2 \mathrm{~m}$, and $4 \mathrm{~m}$ natural color 2006 and pre-2006 images). Cell perimeters were determined by the presence of levees, and a total of 969 were delineated. Based on an average levee height of 1-2 m, with outlet pipes positioned at approximately $0.5 \mathrm{~m}$, we calculated volumes based on water depths ranging from $0.1 \mathrm{~m}$ to maximum fill $(0.5 \mathrm{~m})$. Our estimates do not consider upland topography within cells, and assume uniform bathymetry.

$$
\text { Volume }=A \times F_{m} \times D \text {, }
$$

Where $A=$ Surface area of the wetland $\left(\mathrm{m}^{2}\right), F_{m}=$ dimensionless factor to modify surface area. At maximum fill level, it is assumed that water will cover 100 percent of the wetlands surface area resulting in a value equal to one; where a wetland has sloping banks, surface area below maximum fill level generally is reduced by a certain fraction $\left(\mathrm{F}_{m}\right)$. Because of the near-vertical slope of most CCV wetland cells, $F_{m}$ was set to one for this study. $D=$ depth (m) (After Liu and others, 2008).

\section{Method 2: Field Measurements}

Floodwater storage capacity was measured at 17 WRP sites in the summer 2009. A Sokkia SET530R3 total station (Prism Surveying \& Construction Systems, Inc., San Diego, CA) and Global Positioning System (GPS) unit (Garmin GPS 12, minimum accuracy of $\pm 15 \mathrm{~m}$ ) were used to survey WRP cell bathymetry. WRP easements were divided into smaller survey parcels to allow accurate sighting of survey points and proper functioning of the total station laser. These parcels corresponded to WRP cells.

Sites were surveyed using two transects per cell, with survey points every $250 \mathrm{~m}$ along each transect. Levee points at all four corners of the site and at one-half way between each corner, as well as at every interior levee point encountered, were surveyed. This made for an average of 19.7 points per parcel. Data at each point were collected in relation to the total station setup location, and included survey point type (levee, resectioning, inlet or interior), and the northing, easting and $\mathrm{z}$ (depth) in relation to the total station.

UTM northing and easting also were recorded with the GPS unit at all survey and total station setup points. Drainage outlets to each wetland cell were identified with the assistance of NRCS field office staff, NWR employees, and landowners, and the height of outlet drainage pipes or of the topmost outlet flashboard relative to total station setup location were measured at subsequent field visits. 
Survey northing, easting, and $\mathrm{z}$ data were then manually entered into Microsoft ${ }^{\circledR}$ Excel and projected into ArcMap 9.3 over National Agriculture Imagery Program (NAIP) 2006 aerial imagery showing individual wetland cells. In ArcMap, projected points were modeled in 3-D using an array of methods.

Volumes were estimated by creating a Triangulated Irregular Network (TIN) in ArcMap 9.3, using the Spatial Analyst Extension. A surface analysis can be run from a TIN, with an output that contains the parcel's surface area and volume. We included all collected points with z-values lower than the lowest levee point's z-value and added additional points to form the actual boundary of the parcel.

\section{Results}

A comparison of the two methods indicates that on average (excluding site 12), volumetric estimates assuming a flood depth of $0.4 \mathrm{~m}$ were closer to field measurements (table E1) indicated by relatively lower deviations (average $=-3.0 \pm 41.4$ standard deviation) from the field measurements.

Table E1. Comparison between Method 1 (volumes estimated from cell perimeters) and Method 2 (field measurements) at multiple depths (m).

[Values are percent deviations from Method 2]

\begin{tabular}{|c|c|c|c|c|c|}
\hline \multirow[b]{2}{*}{ Site } & \multicolumn{5}{|c|}{ Percent deviation from Method 2 at $0.1 \mathrm{~m}$ depth intervals } \\
\hline & 0.1 & 0.2 & 0.3 & 0.4 & Max Fill (0.5) \\
\hline 1 & 75.0 & 50.0 & 25.0 & 0.1 & -24.9 \\
\hline 2 & 84.1 & 68.1 & 52.2 & 36.3 & 20.4 \\
\hline 3 & 67.9 & 35.8 & 3.8 & -28.3 & -60.4 \\
\hline 4 & 78.8 & 57.7 & 36.5 & 15.4 & -5.8 \\
\hline 5 & 85.7 & 71.5 & 57.2 & 43.0 & 28.7 \\
\hline 6 & 80.3 & 60.6 & 40.8 & 21.1 & 1.4 \\
\hline 7 & 78.7 & 57.5 & 36.2 & 14.9 & -6.3 \\
\hline 8 & 65.3 & 30.5 & -4.2 & -38.9 & -73.6 \\
\hline 9 & 52.1 & 4.1 & -43.8 & -91.8 & -139.7 \\
\hline 10 & 51.6 & 3.2 & -45.3 & -93.7 & -142.1 \\
\hline 11 & 73.2 & 46.4 & 19.7 & -7.1 & -33.9 \\
\hline 12 & -3.7 & -107.4 & -211.1 & -314.7 & -418.4 \\
\hline 13 & 80.4 & 60.9 & 41.3 & 21.8 & 2.2 \\
\hline 14 & 79.2 & 58.4 & 37.6 & 16.8 & -4.1 \\
\hline 15 & 84.6 & 69.2 & 53.7 & 38.3 & 22.9 \\
\hline 16 & 75.1 & 50.2 & 25.4 & 0.5 & -24.4 \\
\hline 17 & 75.9 & 51.7 & 27.6 & 3.5 & -20.7 \\
\hline $\begin{array}{l}\text { Average }^{1} \\
\text { (Standard }\end{array}$ & & & & & \\
\hline Deviation) & $74.2(10.4)$ & $48.5(20.7)$ & 22.7 (31.1) & $-3.0(41.4)$ & $-28.8(51.8)$ \\
\hline
\end{tabular}

\footnotetext{
${ }^{1}$ Averages exclude site number 12 .
} 


\section{Discussion and Way Forward}

Our primary objective of this analysis was methodological comparison. Our results suggest that volumetric estimates should assume relatively higher flood depths. Assuming an overall flood depth of $0.4 \mathrm{~m}$, we estimated that all WRP easements in the CCV provide a combined total of between 3,287 ha-m and 16,437 ha-m of floodwater protection. Assuming lower flood depths may actually underestimate storage volumes because the volumetric estimate method assumes uniform bathymetry, whereas in reality, WRP easements typically include excavated areas, such as swales and ponds that increase storage. However, we strongly suggest additional surveys be conducted to minimize errors in actual storage volume. Most WRP easements are heavily modified and engineered, therefore variability among individual easements limits our ability to over-generalize their floodwater storage capacity. Furthermore, younger easements may undergo significant changes in storage as more features are added, while older sites may experience reductions in storage due to erosion, sedimentation, and vegetative growth.

Future analysis will include an assessment of spatial patterns, such as the distribution of WRP easements within floodplains. This would yield important information regarding their ability to serve as floodwater catchments. We assumed volumetric estimates based on field measurements would be more accurate given that the height of the drainage outlet limits waterholding capacity. 


\title{
Chapter F: Bird Use of Wetland Reserve Program (WRP) in the California's Central Valley (CCV)
}

\author{
By Sharon N. Kahara, Humboldt State University, and Ryan DiGaudio, Point Reyes Bird Observatory
}

\section{Introduction}

The CCV is the most important waterfowl wintering area in the Pacific Flyway, supporting more than 60 percent of the total Flyway population in most years (Central Valley Joint Venture, 2006a). The northern CCV is potentially the most important region for breeding waterfowl based on the distribution of potential upland nesting cover, rice fields and wetlands (Central Valley Joint Venture, 2006a). The CCV was historically grassland, with between 1.6 and 2.4 million ha of wetland habitat, now only about 8,100 ha of wetland remain. Most of these are privately managed and are threatened by population growth in urban areas, placing heavy demands on dwindling water supplies. Water from managed systems is becoming increasingly expensive and unreliable with increasing urban demands. In privately managed wetlands, semipermanent and seasonal wetland areas decrease from north to south and upland habitat (grassland and hay) is most abundant in the Sacramento subbasin and lowest in the San Joaquin subbasin (Central Valley Joint Venture, 2006a).

The Grasslands Ecological Area located in the San Joaquin subbasin, and is recognized as a Wetland of International Importance by the Western Hemisphere Shorebird Reserve Network. The GEA is a 64,700 ha mosaic of grassland, riparian, and depressional wetlands and supports more shorebirds than any other inland site in North America during winter and spring (Central Valley Joint Venture, 2006a; Hickey and others, 2008). The GEA also is one of a few key wintering areas in the world for mountain plovers (Charadrius montanus) (Knopf and Rupert, 1995).

We surveyed bird use of WRP wetlands in the CCV to evaluate the avian use of WRPs along latitudinal, age and management gradients. We also examined relationships between bird use and habitat characteristics.

\section{Methods}

In 2008, bird surveys were conducted at 42 CCV WRP properties and two NWR sites. In 2009, birds were surveyed at 16 CCV WRP properties. All surveys were conducted by Point Reyes Conservation Science staff. Three survey methods were used: (1) point counts in uplands, (2) area searches in uplands, and (3) scan-sampling surveys in wetlands (appendix III, table III1). These survey methods provide information on species occurrence, as well as secondary population parameters such as abundance (or density), species richness, and species diversity. Species observed were grouped into 11 foraging guilds comprised of species that share behavioral traits and have similar environmental requirements (Hickey and others, 2008).

\section{Point Counts}

Five-minute variable circular point count surveys were conducted in accessible upland habitat following nationally standardized protocol (Ralph and others, 1995). In 2008, eight WRP properties and two NWR sites were surveyed by point count, and in 2009, four WRP properties were surveyed. Counts occurred between sunrise and 1000 h between May 3 and June 13, 2008 
and May 1 and June 25, 2009. For the 5-min variable circular plot point count method, the distance from the observer to each individual bird (including aerially foraging raptors and swallows) was estimated (Ralph and others, 1995).

We estimated detections in bands of $10 \mathrm{~m}$ outward to $50 \mathrm{~m}$. Three bands extend farther (50-75 m, 75-100 m, and >100 m). Distances to birds were estimated with the aid of range finders. Type of detection (that is song, visual, or call) and breeding behavior (for example, copulation, nest building, food carry to fledgling) were recorded. Birds flying over the point count station were recorded separately and excluded from analyses. All transects were surveyed 2 to 3 times $\geq 10$ days apart during the height of songbird breeding (May-June). Surveys were completed within $4 \mathrm{~h}$ of local sunrise by experienced observers trained in visual and auditory bird identification and distance estimation. Because detection rates of most species generally decrease beyond a $50 \mathrm{~m}$ distance from the observer, we have only included detections from within $50 \mathrm{~m}$ of each point count station for data analysis.

\section{Area Searches}

In 2008, two WRPs in the Sacramento subbasin were surveyed between May 5 and July 1. In 2009, area searches were conducted on May 20 and June 11 at one of the WRP easements surveyed by area searches in the preceding year. Surveys followed protocol described by Ralph and others (1995). Area searches consisted of 20-min searches in which a trained observer moved around in a predetermined area search plot. These surveys may be used to assess areas that are not adequately surveyed by other methods (for example sites that are too small for point counts).

\section{Wetland Surveys}

Scan-sampling (Reed and others, 1997) was used to survey wetland sites approximately once every 3 weeks. The 3-week survey interval allowed us to visit all the sites in our study area and conduct enough surveys at each site to capture a range of bird use through the survey period. In 2008, two NWR sites and 39 WRP properties were surveyed between April 10 and December 9. Late summer and fall surveys were restricted to the Tulare subbasin to assess seasonal variation in wetland bird populations.

In 2009, wetland surveys were conducted at 13 WRPs between April 19 and July 16. Wetlands were searched from various vantage points for optimal survey coverage of each site. All bird species seen or heard in the wetland, including those aerial feeding, were recorded. Flying birds, other than those foraging aerially, were not recorded. Species counts were obtained for large flocks by estimating a block of birds within a given flock. Survey time and duration varied with number of birds, number of wetlands on the property, and size of the wetland(s).

\section{Statistical Analysis}

Point count data and wetland surveys were analyzed separately by Kruskall-Wallis oneway ANOVA by ranks to assess differences along subbasin and management gradients. MannWhitney U-tests were used to assess differences between age categories. 


\section{Results}

\section{Upland Surveys}

Bird species diversity did not differ by subbasin, management intensity, or restoration age; however, bird diversity was significantly greater in July than in May at all sites in 2009 (table $\mathrm{F} 1 ; \mathrm{t}=-3.56, \mathrm{P}=0.04$ ). Upland bird species were more common than other species in this zone (table F2). Species richness was greater in low or inactively managed sites. Fourteen special status species were observed on upland portions of sites throughout the CCV. Special status species appear in at least one of the following lists of threatened or endangered birds: Shuford and Gardali (2008), California Department of Fish and Game (2009), U.S. Fish and Wildlife Service (2008), or International Union for Conservation of Nature (2006).

We found significantly greater abundance of aerial feeders and marsh birds in the Sacramento subbasin. Aerial feeders, marsh birds and upland birds were most abundant in heavily managed sites. Foraging guilds did not differ by restoration age. Aerial feeders, aerial predators, large wading birds, dabbling ducks, shorebirds, and upland birds were most frequently observed on sites in the Sacramento subbasin.

All foraging guilds except upland birds occurred most frequently on heavily managed sites. All guilds were observed more frequently on older sites, except marsh birds, which were more frequent on younger sites.

Table F1. Temporal variation in bird species diversity (transformed Shannon-Weiner Index) in the upland zone of four sites surveyed.

[The first visit took place on May 1 and the second on June 25, 2009]

\begin{tabular}{lccc}
\hline & Site & Visit 1 & Visit 2 \\
\hline SAC-20 & 2.86 & 3.60 \\
SAC-13 & 1.39 & 1.97 \\
SAN-1 & 1.00 & 1.42 \\
SAN-6 & 1.81 & 1.93 \\
\hline
\end{tabular}


Table F2. Percent occurrence of foraging guilds by subbasin, management and age.

[Number of sites is indicated in parentheses. Sac $=$ Sacramento and San $=$ San Joaquin. "Young" sites are $\leq 5$ years since restoration; "Old" are > 5 years. "Low" = sites under low or no management; "Inter" = sites under intermediate management; "High" = actively managed sites. Management intensity categories are defined in appendix I, table I3. Guilds are defined in Hickey and others (2008)]

\begin{tabular}{|c|c|c|c|c|c|c|c|}
\hline \multirow[b]{2}{*}{ Guild } & \multicolumn{2}{|c|}{ Subbasin ( percent) } & \multicolumn{3}{|c|}{ Management ( percent) } & \multicolumn{2}{|c|}{ Age ( percent) } \\
\hline & $\begin{array}{l}\text { Sac } \\
(21)\end{array}$ & $\begin{array}{l}\text { San } \\
(29)\end{array}$ & Low (8) & $\begin{array}{c}\text { Inter } \\
\text { (23) }\end{array}$ & $\begin{array}{l}\text { High } \\
(20)\end{array}$ & $\begin{array}{c}\text { Young } \\
\text { (37) }\end{array}$ & $\begin{array}{l}\text { Old } \\
\text { (13) }\end{array}$ \\
\hline Aerial feeders & 71 & 7 & 38 & 9 & 60 & 23 & 38 \\
\hline Aerial predators & 10 & 3 & 0 & 4 & 10 & 0 & 8 \\
\hline Large waders & 5 & 0 & 0 & 0 & 5 & 0 & 3 \\
\hline Dabbling ducks & 19 & 0 & 12 & 0 & 15 & 8 & 8 \\
\hline Marsh birds & 71 & 7 & 88 & 9 & 40 & 54 & 27 \\
\hline Shorebirds & 5 & 0 & 0 & 0 & 5 & 0 & 3 \\
\hline Upland birds & 95 & 93 & 75 & 100 & 90 & 77 & 100 \\
\hline
\end{tabular}

\section{Wetland Surveys}

In 2008, 203 species of birds were recorded and in 2009, 111 species of birds were recorded. Species were classified under 11 guilds (table F3).

Species diversity (measured as the transformed Shannon-Weiner Index) did not differ among subbasins, management or age treatments; however, species richness was significantly greater in the San Joaquin subbasin (fig. F1). Thirty-one special status species were observed on wetland portions of WRP sites in 2008 and 14 in 2009 (appendix III, tables III-2 and III-3).

Aerial predators were significantly more abundant in the Tulare subbasin (fig. F2). More geese were observed in the Sacramento subbasin (fig. F3) and marsh birds were most abundant in the San Joaquin subbasin (fig. F4). Dabbling ducks, geese, and shallow divers were more abundant on heavily managed sites than those sites managed under intermediate or low regimes (figs. F5, F6, and F7). Upland birds were significantly more abundant on sites restored more than 5 years ago (fig. F8). Breeding shorebirds were most abundant in the San Joaquin subbasin (fig. F9).

In the Tulare subbasin, aerial feeders, Ciconiiformes, dabbling ducks, and shallow divers were significantly more abundant on actively managed sites (figs. F10-F13). Shorebirds were most abundant on intermediately managed sites (fig. F14). 
Table F3. Number of species in each avian guild observed in California's Central Valley.

\begin{tabular}{lcc}
\hline \multicolumn{1}{c}{ Guild } & \multicolumn{2}{c}{ Number of species } \\
\cline { 2 - 3 } & $\mathbf{2 0 0 8}$ & $\mathbf{2 0 0 9}$ \\
\hline Aerial Feeders & 19 & 8 \\
Aerial Predators & 18 & 8 \\
Large Waders & 8 & 6 \\
Dabbling Ducks & 14 & 9 \\
Geese and Swans & 4 & 2 \\
Gulls & 4 & 1 \\
Marsh Birds & 12 & 11 \\
Plunge Divers & 5 & 1 \\
Surface Divers & 15 & 8 \\
Shorebirds & 32 & 16 \\
Upland Birds & 72 & 49 \\
\hline
\end{tabular}

\section{Trends}

Average species richness in the Sacramento peaked in April, although in the Tulare, the greatest numbers of species were observed in September (fig. F15). Average number of birds observed per visit in the Sacramento and Tulare was highest in early September, while in the San Joaquin the greatest abundance appears to occur in late April (fig. F15). Breeding shorebird abundance peaked in early April in the San Joaquin, while in the Tulare peaks were observed in late May and July (fig. F16).

\section{Dominant Species by Guild}

Dabbling ducks - Mallards (Anas platyrhynchos) were most common, occurring on 88 percent of sites in 2008 and 92 percent of sites in 2009.

Geese - Canada geese (Branta canadensis) occurred most frequently in both years (17 and 42 percent, respectively).

Marsh birds - Red-winged blackbirds (Agelaius phoeniceus) occurred most frequently in both years (94 and 92 percent respectively).

Plunge divers - In 2008, Forster's terns (Sterna forsteri) were the most frequently observed (17 percent). In 2009, only the belted kingfisher (Megaceryle alcyon) was observed on one site.

Gulls - In 2008, California gulls (Larus californicus), herring gulls (L. smithsonianus), ring-billed gulls (L. delawarensis) and an unidentified gull (Larus spp.) all occurred on 2 percent of all sites. In 2009, only ring-billed gulls were observed at two sites. 
Shallow divers - Pied-billed grebes (Podilymbus podiceps) were the most common species observed in both years (48 and 58 percent).

Shorebirds - Killdeers (Charadrius vociferus) were the most frequently observed species in 2008 (79 percent), while black-necked stilts (Himantopus mexicanus) were most frequently observed in 2009 (75 percent).

Upland birds - Brown-headed cowbirds (Molothrus ater) were the most common in both years (64.6 and 100 percent).

Aerial predators - Northern harriers (Circus cyaneus) were the most frequently observed species in 2008 (65 percent), and red tailed hawks (Buteo jamaicensis) were the most common in 2009 (75 percent).

Breeding birds - In 2008, breeding shorebirds were significantly more abundant in the San Joaquin subbasin (fig. F9). Shallow diver broods were significantly more abundant in heavily managed sites (fig. F7). Site age did not affect breeding bird abundance.

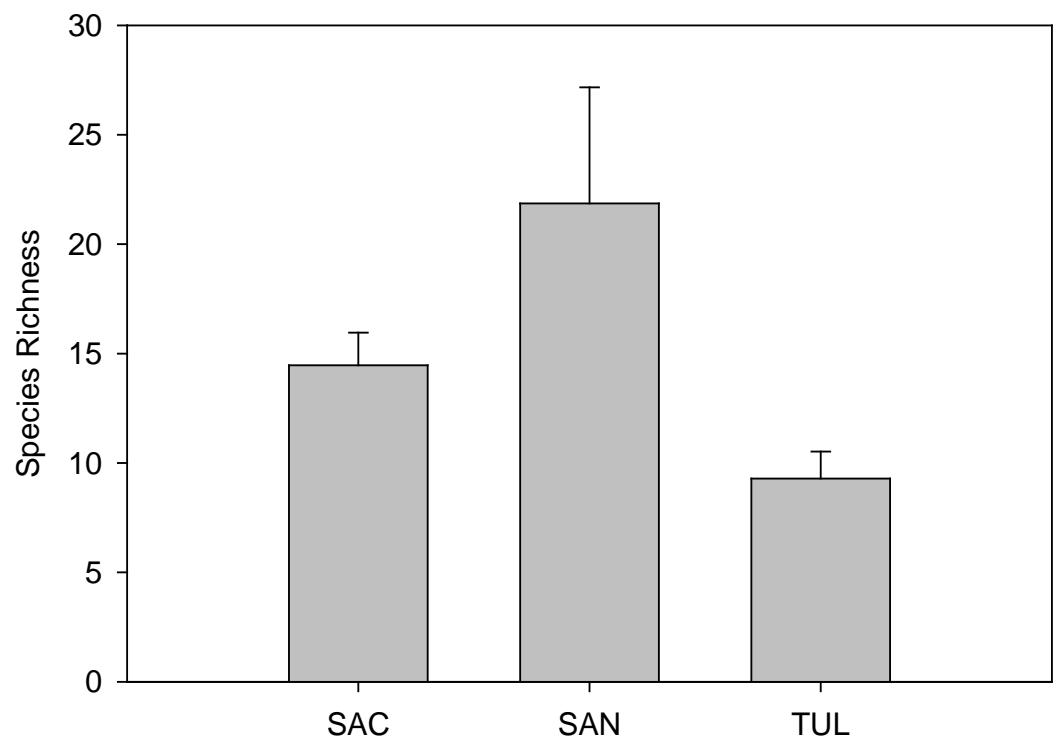

Figure F1. Average bird species richness (transformed Shannon-Weiner Index) by subbasin. SAC = Sacramento, SAN = San Joaquin, and TUL = Tulare. Standard error bars shown. 


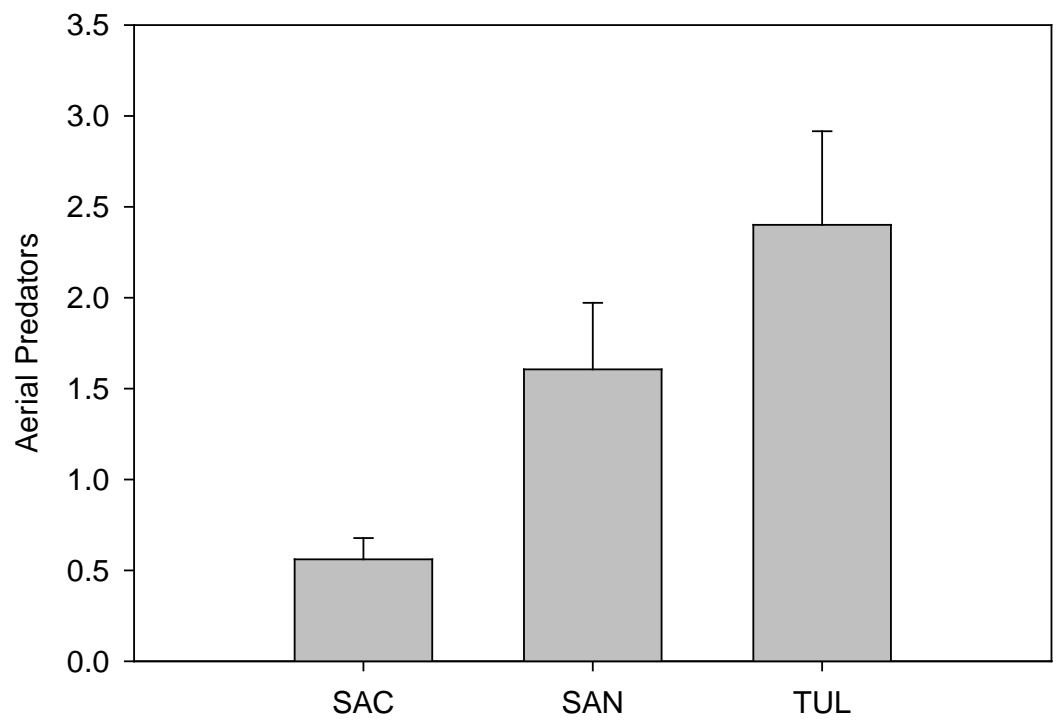

Figure F2. Average abundance of aerial predators by subbasin. $\mathrm{SAC}=$ Sacramento, $\mathrm{SAN}=\mathrm{San}$ Joaquin, and TUL = Tulare. Standard error bars are shown.

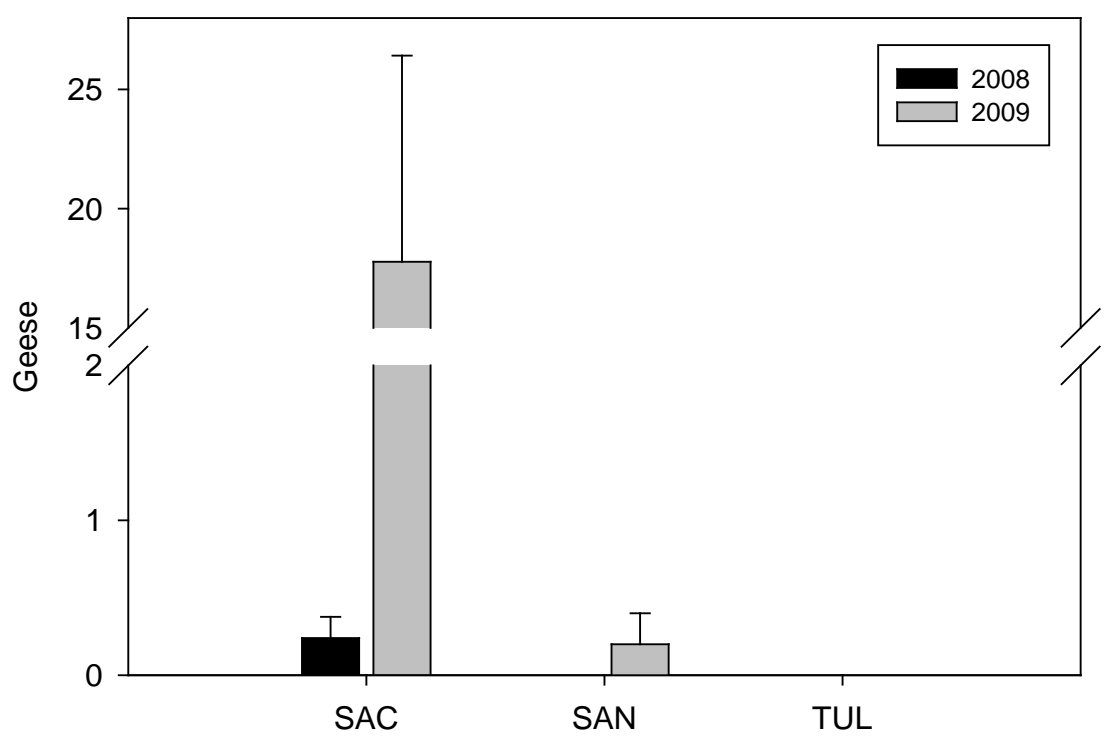

Figure F3. Average abundance of geese (Anser spp., Branta spp. and Chen spp.) by subbasin. SAC = Sacramento, SAN = San Joaquin, and TUL = Tulare. Standard error bars are shown. 


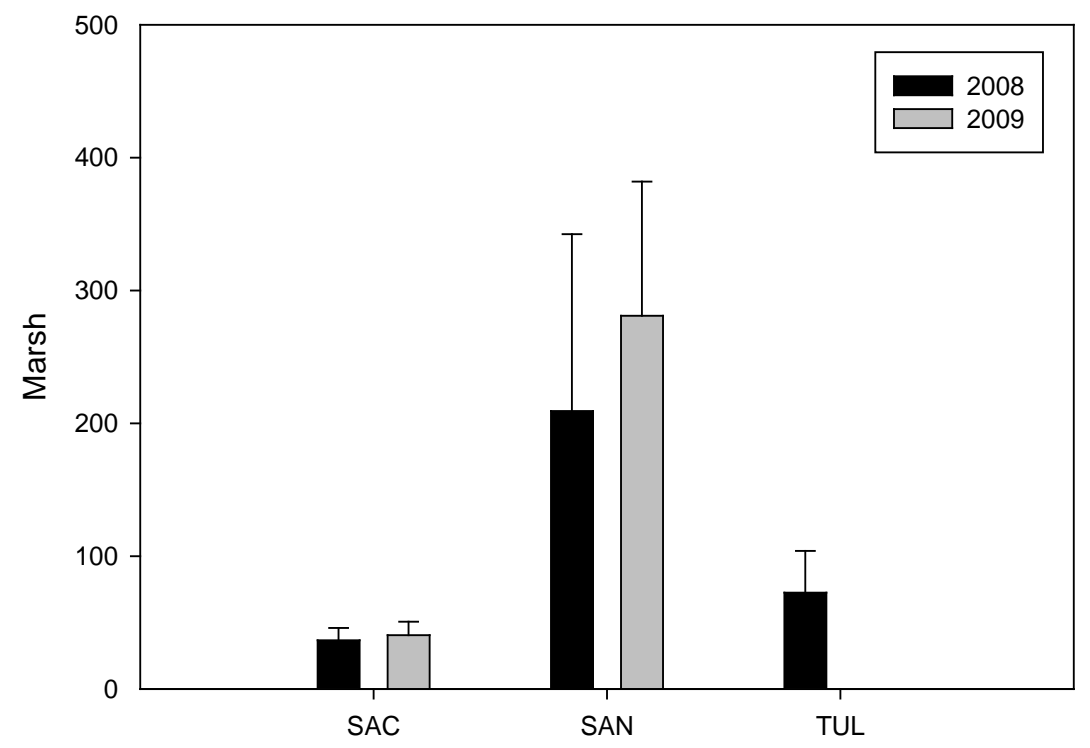

Figure F4. Average abundance of marsh birds by subbasin. $S A C=$ Sacramento, $S A N=$ San Joaquin, and TUL = Tulare. Standard error bars are shown. 


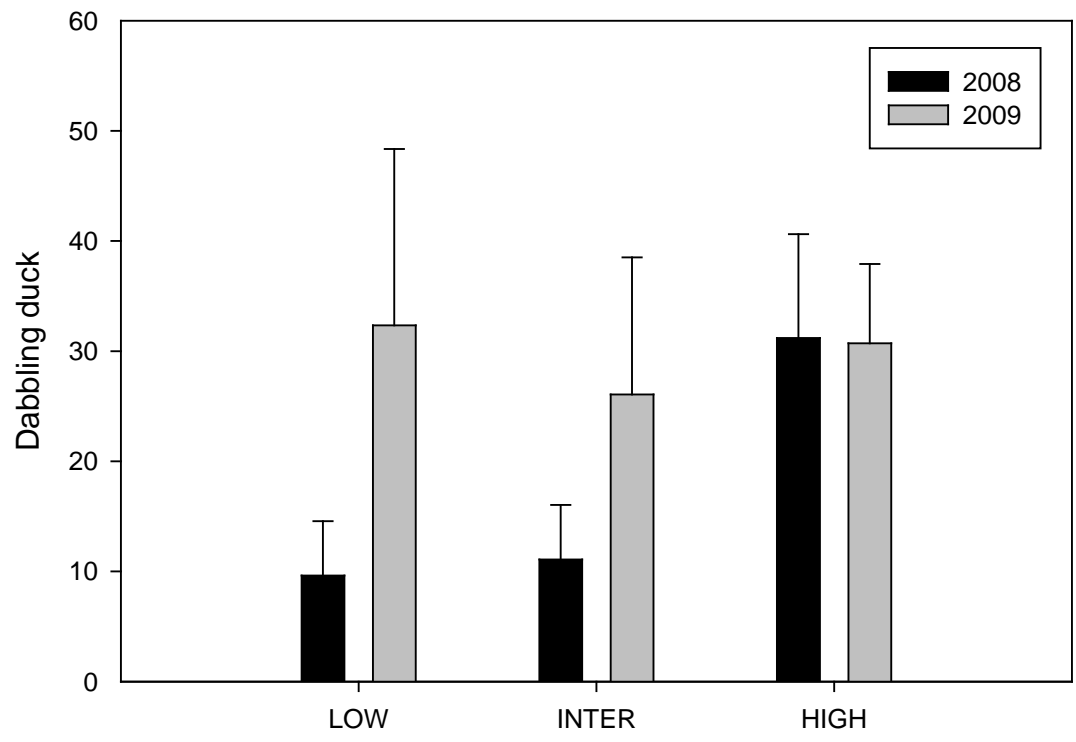

Figure F5. Average abundance of dabbling ducks (Anas spp.) by management. LOW = sites under low or no management, INTER = sites under intermediate management, $\mathrm{HIGH}=$ actively managed sites. Management intensity categories are defined in appendix I, table I3. Standard error bars are shown.

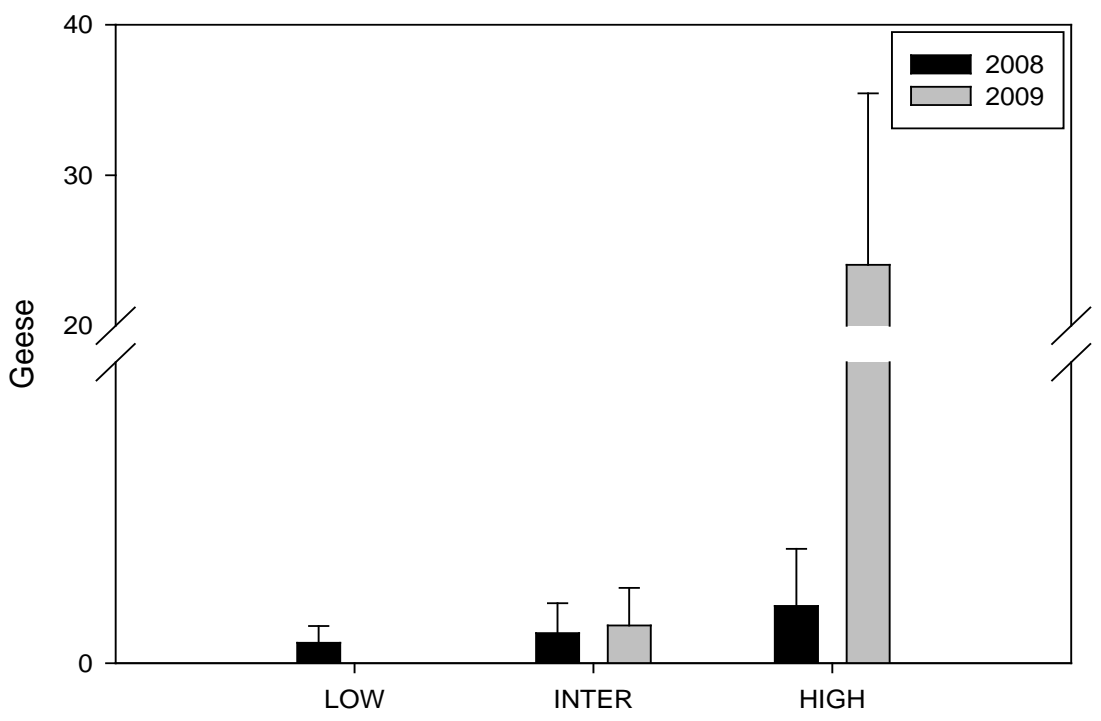

Figure F6. Average abundance of geese by management. LOW = sites under low or no management, INTER = sites under intermediate management, $\mathrm{HIGH}=$ actively managed sites. Management intensity categories are defined in appendix I, table I3. Standard error bars are shown. 


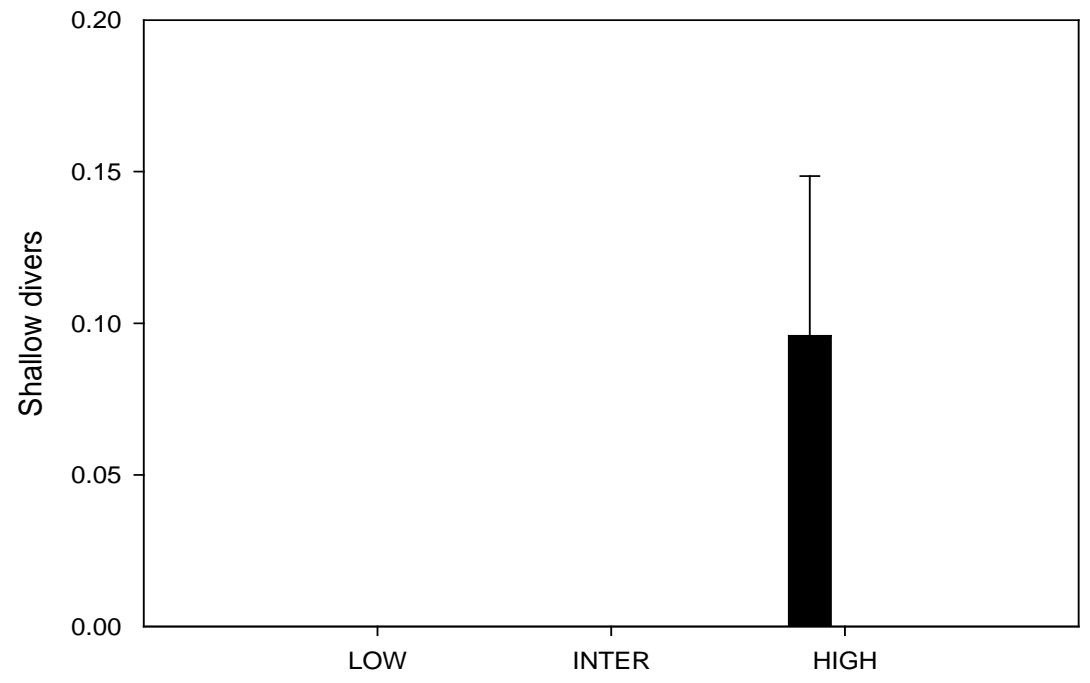

Figure F7. Average abundance of shallow diver broods by management. LOW = sites under low or no management, INTER = sites under intermediate management, $\mathrm{HIGH}=$ actively managed sites. Standard error bars are shown.

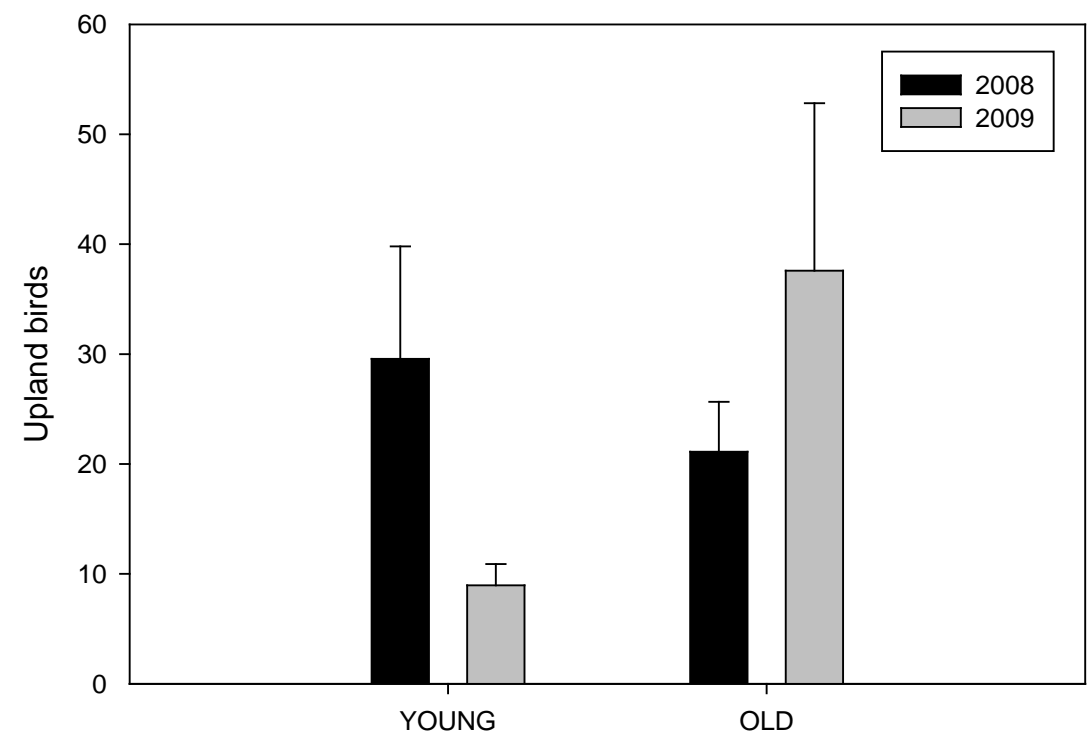

Figure F8. Average abundance of upland birds by WRP age. "Young" sites are $\leq 5$ years since restoration; "Old" are $>5$ years. Standard error bars are shown. 


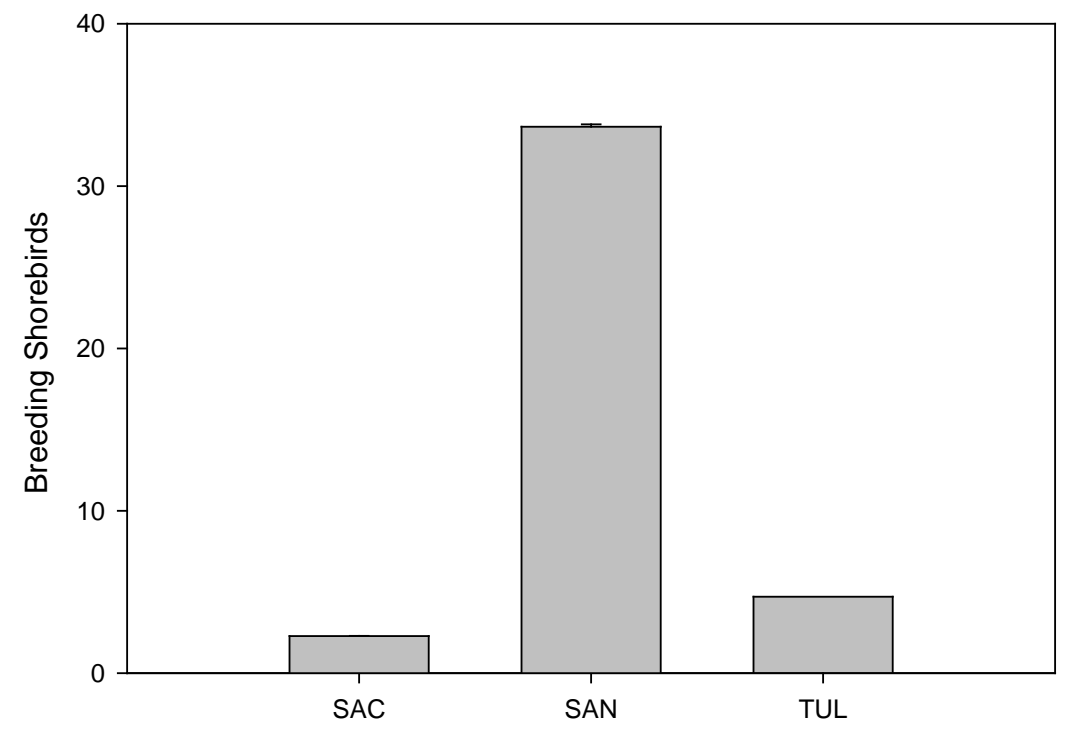

Figure F9. Average abundance of breeding shorebirds by subbasin. SAC = Sacramento, SAN = San Joaquin, and TUL = Tulare.

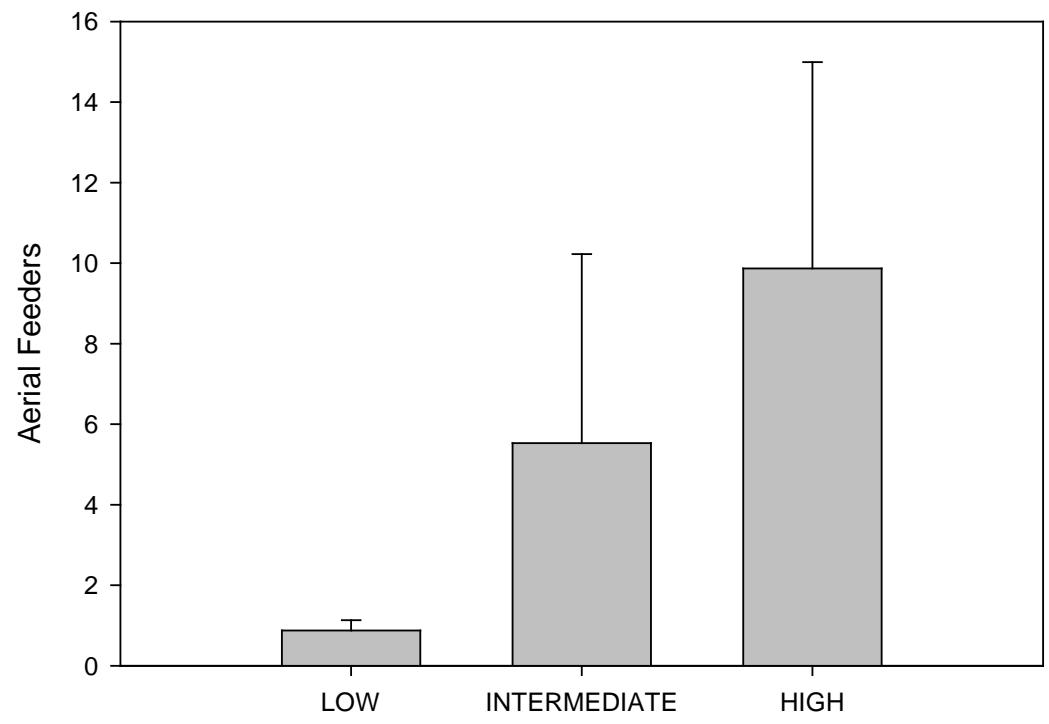

Figure F10. Average abundance of aerial feeders by management in the Tulare subbasin. LOW = sites under low or no management, INTERMEDIATE = sites under intermediate management, $\mathrm{HIGH}=$ actively managed sites. Standard error bars are shown. 


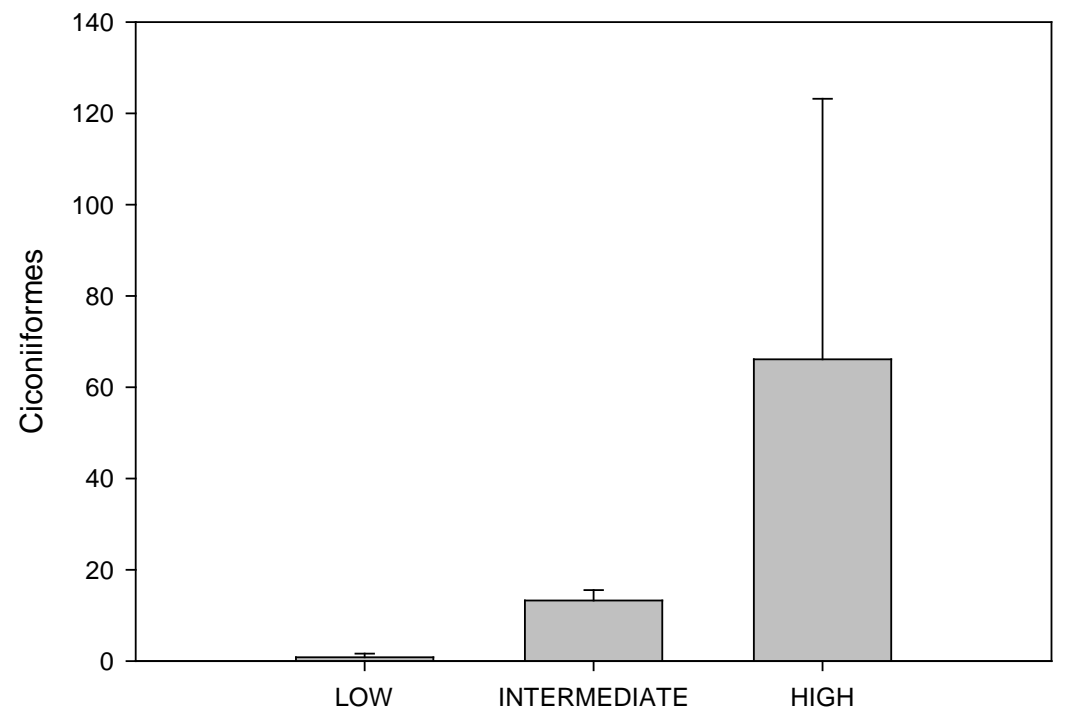

Figure F11. Average abundance of ciconiiformes by management in the Tulare subbasin. LOW = sites under low or no management, INTERMEDIATE = sites under intermediate management, $\mathrm{HIGH}=$ actively managed sites. Standard error bars are shown.

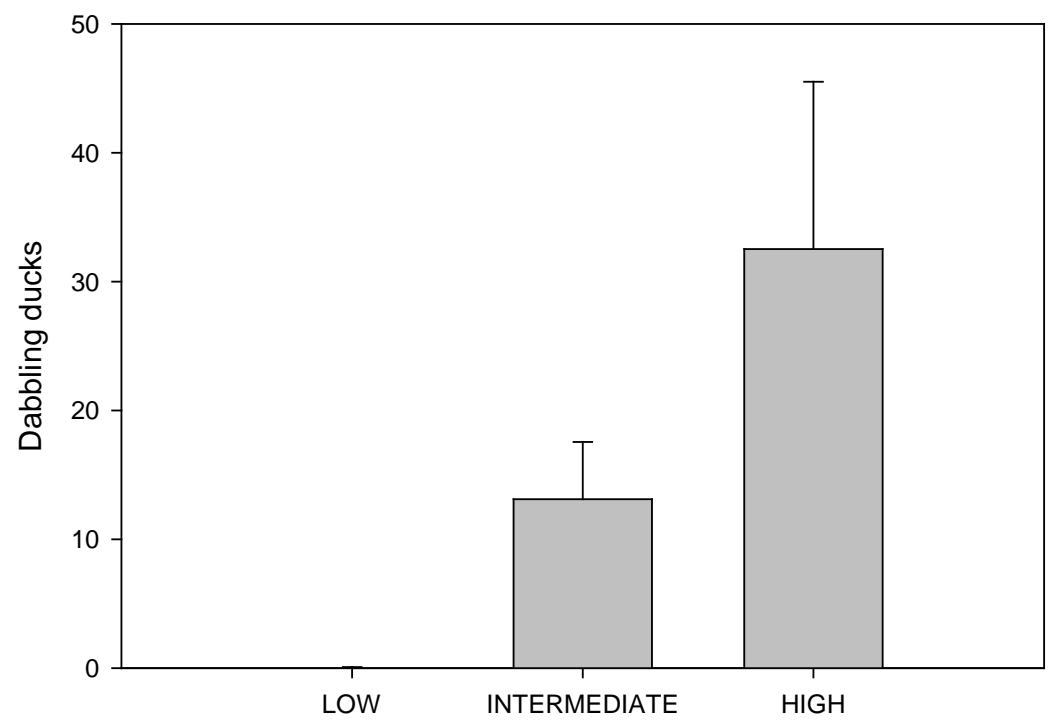

Figure F12. Average abundance of dabbling ducks by management in the Tulare subbasin. LOW = sites under low or no management, INTERMEDIATE = sites under intermediate management, $\mathrm{HIGH}=$ actively managed sites. Standard error bars are shown. 


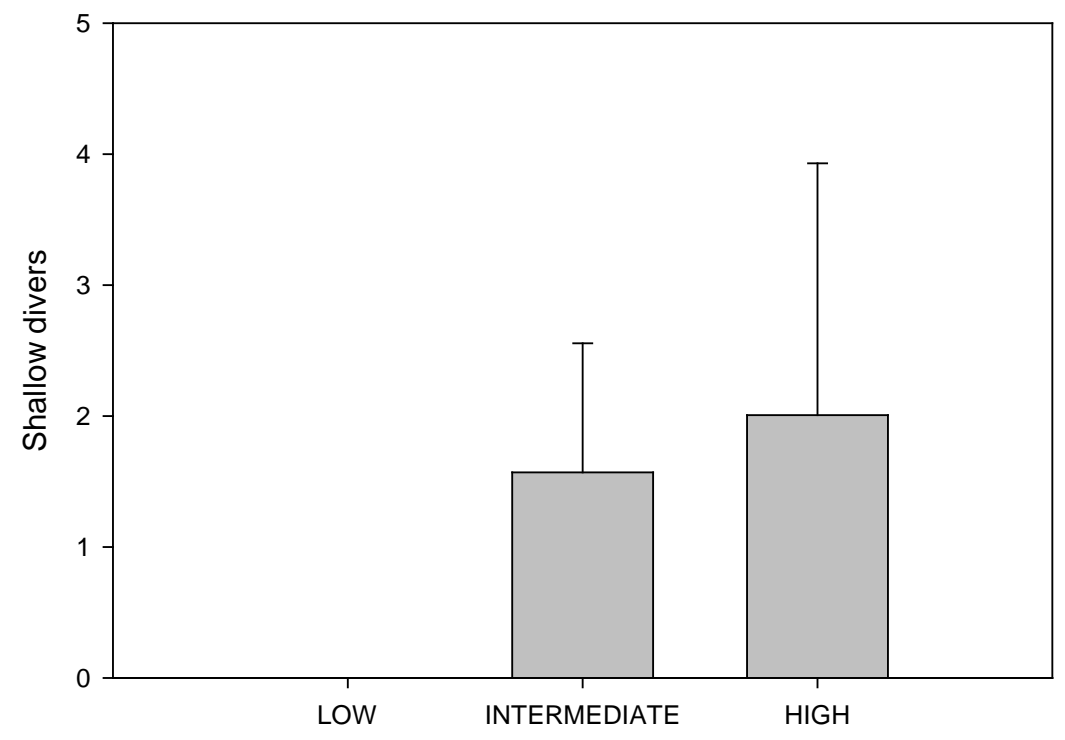

Figure F13. Average abundance of shallow divers by management in the Tulare subbasin, LOW = sites under low or no management, INTERMEDIATE= sites under intermediate management, HIGH = actively managed sites. Standard error bars are shown.

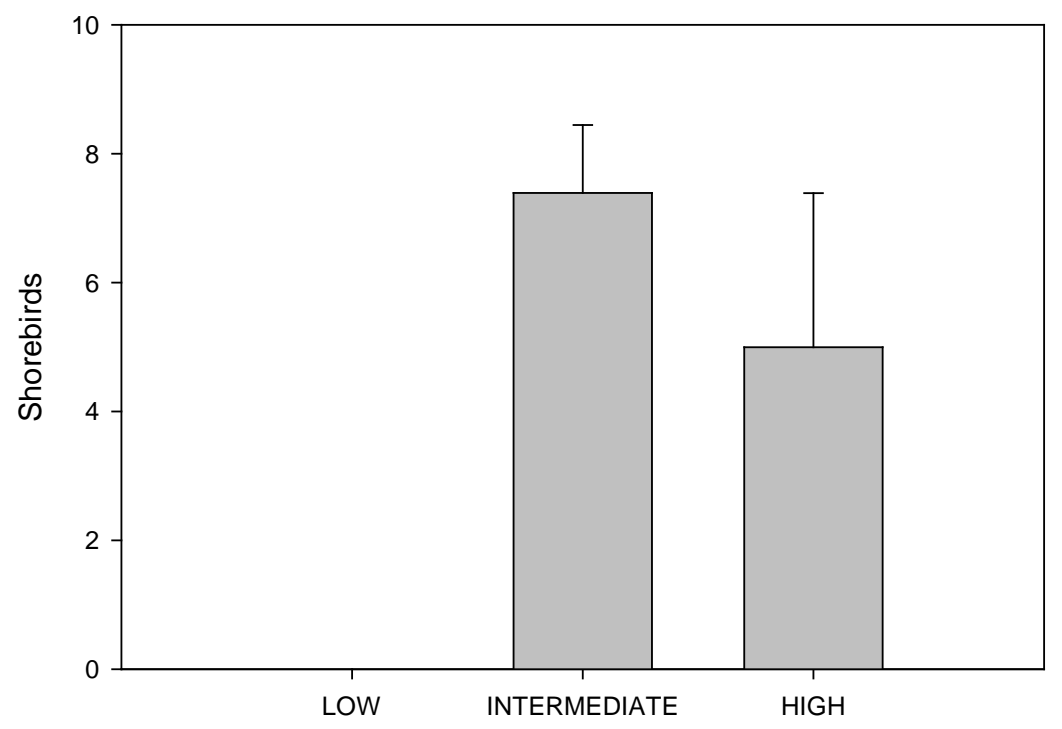

Figure F14. Average abundance of shorebirds by management in the Tulare subbasin. LOW = sites under low or no management, INTERMEDIATE = sites under intermediate management, HIGH = actively managed sites. Standard error bars are shown. 


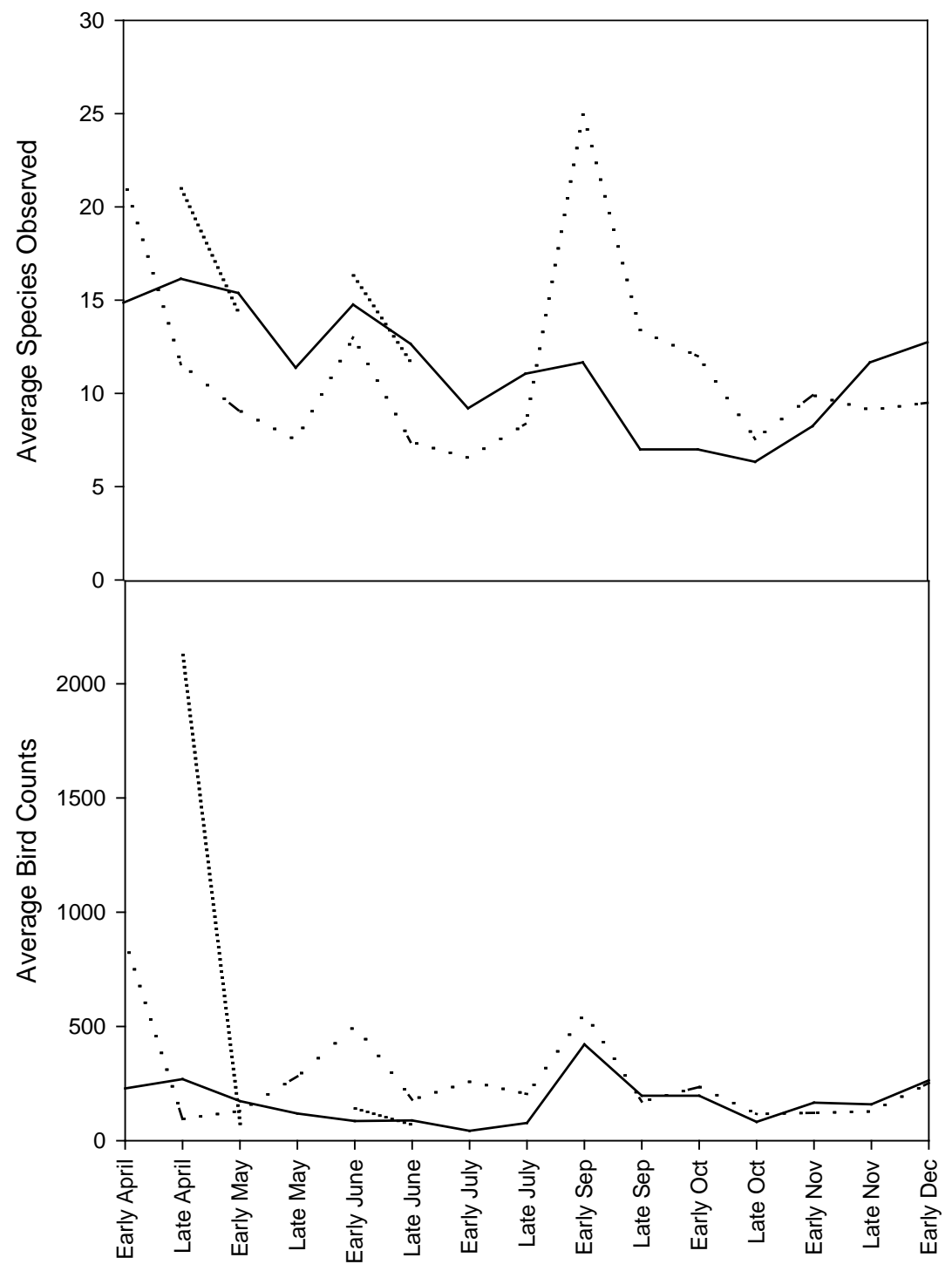

Figure F15. Average number of species and average birds observed per visit in the Sacramento (solid line), San Joaquin (dotted line), and Tulare (dashed line) subbasins from April to December 2008. 


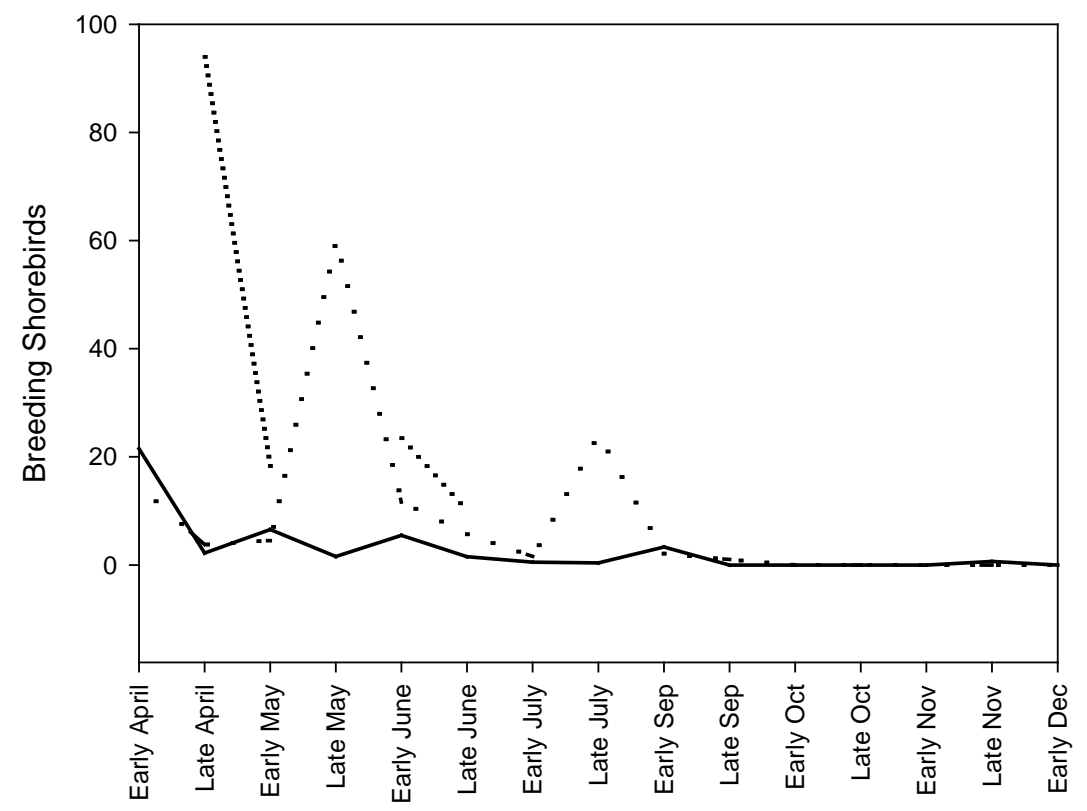

Figure F16. Average number of breeding shorebirds observed per visit in the Sacramento (solid line), San Joaquin (dotted line), and Tulare (dashed line) subbasins from April to December 2008.

\section{Discussion}

About 250 bird species have been recorded in the CCV (Binford, 1986; Engilis, 1995) despite significant conversion of wetland and upland habitats to agriculture and urban uses. Our study detected more than 200 species at sites surveyed in 2008 and 111 in 2009, which are similar to or in some cases higher than numbers observed in other studies conducted in managed sites in the same area (Hickey and others, 2008).

As in other surveys, bird diversity and abundance peaked in April and then again in the late summer and early fall (Gilmer and others, 1998) indicating the return of fall migrants to the region. Historically, early fall migrants overflew the northern CCV and arrived at the large lakes and wetlands in the Tulare subbasin that provided consistent habitat. Once precipitation and flooding filled wetlands of the Sacramento and San Joaquin subbasins, birds would then move north. Although our data do not provide absolute evidence of a return to historical reverse migration, it is suggestive given the dates and numbers (Central Valley Joint Venture, 2006a).

Surveys of the upland portions of WRP indicated higher use by almost all foraging guilds in the Sacramento subbasin compared to the San Joaquin subbasin. Lack of information on the Tulare subbasin precluded assessment. Most of all remaining upland riparian habitat is located in the Sacramento subbasin and may have contributed to higher use (Central Valley Joint Venture, 2006a). Presence of trees within semi-permanent wetlands of the Sacramento valley also was reported to contribute to higher avian biodiversity (Harris, 2001). 
Surveys of WRP indicate that the Sacramento subbasin supported a higher number of geese, whose numbers were positively correlated to the proportion of wet meadow and open water zones in WRP. Wet meadow and open water zones were significantly larger on sites in the Sacramento subbasin than sites farther south. Wet meadow zones typically are dominated by short annual wetland species that may be favored by grazing birds such as geese. The Sacramento subbasin also supports a greater proportion of crops such as rice, small grains and pasture, which also may be attractive to grazing species such as geese.

Surveys conducted on the wetland portions of WRP indicate greater numbers of aerial predators in the Tulare subbasin compared to the Sacramento or San Joaquin subbasins. Aerial predators include species that often prey on wetland birds. Aerial predators were highly correlated with the proportion of upland habitat that dominated sites in the Tulare subbasin. Upland zones on WRP sites typically support grasses such as Distichlis spicata (salt grass) and Phalaris canariensis (reed canarygrass). Furthermore, a large proportion of sites are under low or inactive management. These large expanses of open upland habitat may support aerial predator foraging activity.

Marsh birds occurred in greatest abundance in the San Joaquin subbasin compared to other subbasins. Marsh birds include Red-winged Blackbirds, Marsh Wrens (Cistothorus palustris), American Coots (Fulica americana) and Common Yellowthroat (Geothlypis trichas), among others. Presence of marsh birds was negatively correlated with proportion of upland habitat; however, there was no evidence to show that sites in the San Joaquin subbasin had less upland habitat. Breeding shorebirds also were more abundant in the San Joaquin subbasin. This is in contrast to previous studies that suggest that the Tulare subbasin is more important for breeding shorebirds (Central Valley Joint Venture, 2006a; Hickey and others, 2008).

We also found that species richness was significantly greater in the San Joaquin subbasin than other subbasins. Average number of species observed on WRP peaked in April in the north while farther south, peaks in richness occurred in the fall. Shuford and others (1998) reported greater shorebird species richness in the San Joaquin Valley. However, observations made by the Central Valley Joint Venture, that suggest the Sacramento and Tulare subbasins support more shorebirds than the San Joaquin subbasin. Our data indicates that WRP easements in this region provide important shorebird habitat, despite only 50 percent of landowners managing for them.

Surveys of upland habitat revealed a higher abundance of aerial feeders, marsh birds, and upland birds on heavily managed sites. All foraging guilds except upland birds were observed more frequently on actively managed sites. Intensively managed sites typically receive more active management and conservation practices such as riparian buffer and native grass planting. Although species diversity and richness did not differ statistically among management regimes, data indicate an increasing trend from low to high management.

Surveys of the wetland habitats found a greater abundance of dabbling ducks on actively managed sites. These sites tend to have more dynamic hydrological regimes and many are actively managed to attract breeding and wintering waterfowl. The largest proportion of actively managed sites is located in the Sacramento subbasin; however, previous studies suggest that sites in the Tulare subbasin may receive more use by waterfowl, waterbirds, and shorebirds due to the shortage of alternative habitat. Our data indicated significantly greater dabbling duck use in actively managed sites of both the Sacramento and Tulare subbasins. Geese and shallow divers also were more abundant on actively managed WRP easements. 
Upland species diversity and foraging guild abundance did not differ among restoration age treatments. However, all guilds were observed more frequently on older sites with the exception of marsh birds. Wetland surveys indicated a higher abundance of upland birds on older sites despite older sites exhibiting smaller upland habitat and larger wet meadow and shallow marsh zones. However, older sites may have more riparian habitat. At sites re-vegetated with native plants in the Sacramento River that were more than 5 years old, bird diversity approached that of remnant woodland (Golet and others, 2003). In Iowa, VanRees-Siewert and Dinsmore (1996) found that the mean number of breeding birds was significantly higher in older restored wetlands and that species richness increased with percent cover of emergent vegetation. A shift in bird species composition with wetland age also was reported by VanRees-Siewert and Dinsmore (1996) who found that wetland physiognomy was the most important factor influencing total bird diversity.

In summary, our surveys indicate that WRP easements support a diverse assemblage of avian species that are representative of the CCV as a whole. Despite reported water shortages, greater upland and un-restored acreage in the southern CCV (Tulare subbasin), WRP is providing critical waterfowl habitat, particularly in the early fall months. Improved access to water resources for hydrological management would greatly enhance waterfowl use in the Tulare. We suggest further investigation of the effects of hydrological management on breeding shorebird and other waterfowl use of the San Joaquin Valley. An assessment of landscape factors such as surrounding land use and isolation also should be conducted. 
This page left intentionally blank 


\title{
Chapter G: Amphibians in the California's Central Valley (CCV)
}

\author{
By Luke Groff and Shannon J. Chapin, Humboldt State University
}

\section{Introduction}

Reports indicate worldwide amphibian declines (Diamond, 1996; Halliday, 1998). In the $\mathrm{CCV}$, the greatest declines have occurred in the Sacramento and San Joaquin subbasins (Fisher and Shaffer, 1996). In heavily cultivated landscapes like the CCV, pesticide accumulation, altered hydroperiods, increased sedimentation likely reduce larval survival. Cultivation also may impact metamorphosis and reduce body condition (Ghioca-Robrecht and others, 2010). Improved habitat conditions on WRP easements may provide refuges from agricultural stressors in the CCV, however, use of WRP by amphibians is unknown. Furthermore, differences in hydrology among sites resulting from climate and management may influence use. The objective of 2008 surveys was to evaluate the distribution and relative abundance of anuran species in the CCV.

\section{Methods}

In 2008, 39 WRP easements and 7 NWR sites were surveyed for amphibians using dipnet, visual encounter and aural recording methodologies. Dipnet and visual encounter surveys were conducted during daylight between 0900 and $1600 \mathrm{~h}$. This technique required two surveyors to slowly walk around the wetland perimeter at the waterline, stopping often to scan ahead for amphibians. One surveyor focused on the land-water interface while the other focused on the shallow water zone $(\leq 1 \mathrm{~m})$. Overhangs, ledges, and vegetation were investigated for the presence of amphibians. Surveyors wore polarized sunglasses to reduce the reflective glare on the water's surface and carried dipnets to capture individuals for identification or museum voucher purposes. Collected amphibians were identified using a variety of guides, including Stebbins (2003) and Altig and others (2007).

Aural recordings were used to detect nocturnal breeding activities (that is, vocalizations) of adult, male anurans that may not have been observed during visual surveys. At each WRP easement, a single Wildlife Acoustic SM1 Song Meter (Wildlife Acoustics, Inc., Concord, MA) recorder was installed along the northern perimeter of the wetland. Recorders were programmed to record the first 20 min of each hour between 2000 and $0500 \mathrm{~h}$ (that is, 2000-2020 h, 2100$2120 \mathrm{~h}$, etc.).

Recordings were reviewed at Humboldt State University. The first 5 min (for example, 2000-2005 h, 2100-2105 h, etc.) of each hourly recording was reviewed at a standardized volume and all amphibian vocalizations were identified and tallied. If the first 5- min interval was inaudible (for example, wind, static, bird clamor), the second 5-min interval (for example, 2005-2010 h, 2105-2110 h, etc.) was reviewed, and so on.

To reduce the potential spread of infectious diseases, all organic matter was removed from nets, boots, and other gear before leaving each WRP. These items were scrubbed, soaked in a Quat-128 ${ }^{\mathrm{TM}}$ (Buckeye International, Inc., Maryland Heights, MO) solution (1:60), and rinsed with clean water prior to surveying another site. 


\section{Results and Discussion}

In 2008, only four amphibian species were detected on CCV WRPs. These included the American bullfrog (Lithobates catesbeianus), pacific chorus frog (Pseudacris regilla), western toad (Anaxyrus boreas), and western spadefoot toad (Spea hammondii). The most common species across all WRP easements was the pacific chorus frog, followed by the American bullfrog (fig. G1).

Four species were detected in the Tulare subbasin, two in the Sacramento subbasin, and only one in the San Joaquin subbasin (fig. G2). Fisher and Schaffer (1996) reported valley-wide amphibian declines, with the greatest declines occurring in the Sacramento and San Joaquin subbasins. Introduced predators, such as American bullfrogs, occurred most frequently in the Sacramento and San Joaquin subbasins and likely have a significant impact on species diversity and abundance. Water quality, particularly pesticide concentration, and disease also are plausible causes of low diversity and abundance; however, we did not investigate these stressors. We also acknowledge that our sampling period and lack of repeat surveys may have limited our ability to detect all potential species.

All species occurred most frequently on actively managed sites, however, species richness was higher on sites that were either not managed or under low management (fig. G3). All species except the pacific chorus frog were more common on older WRP easements than younger easements (fig. G4). Although older sites are more likely to be inundated annually, they are subjected to less disturbance by grazing, mowing, and disking practices.

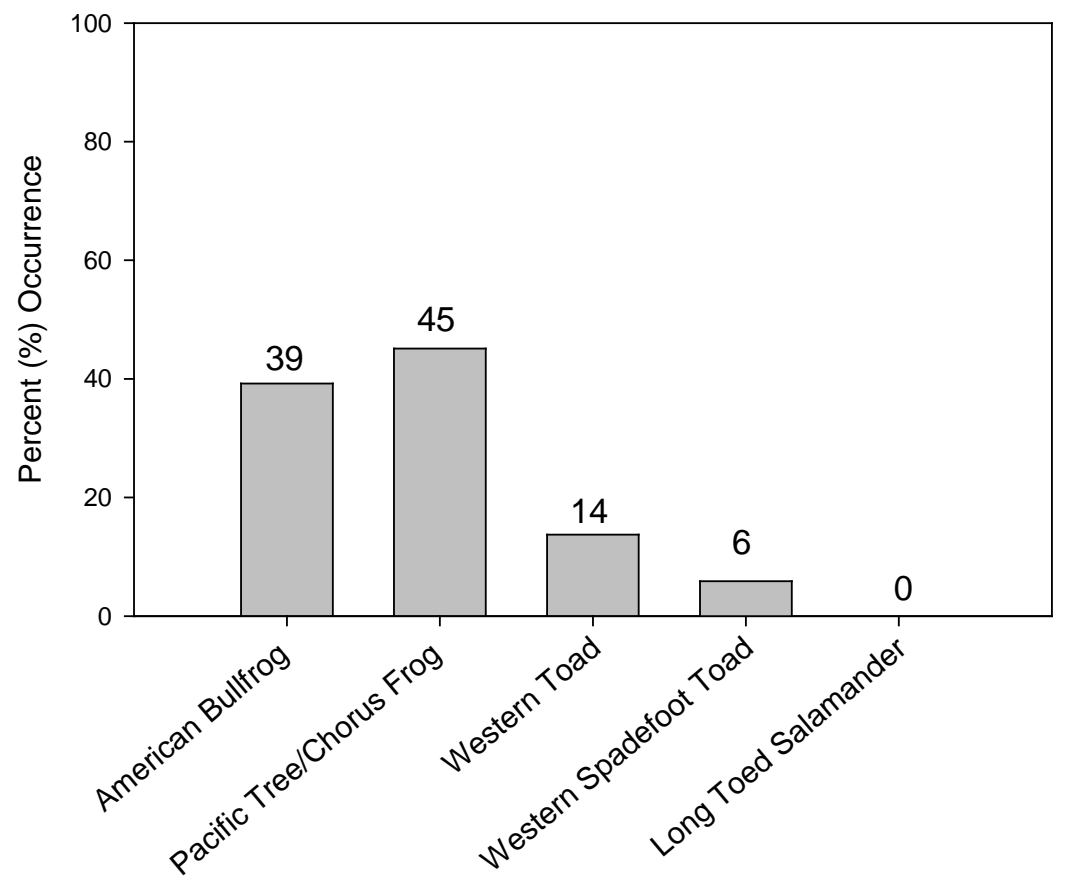

Figure G1. Percent occurrence of each amphibian species recorded on selected WRP easements in 2008. 


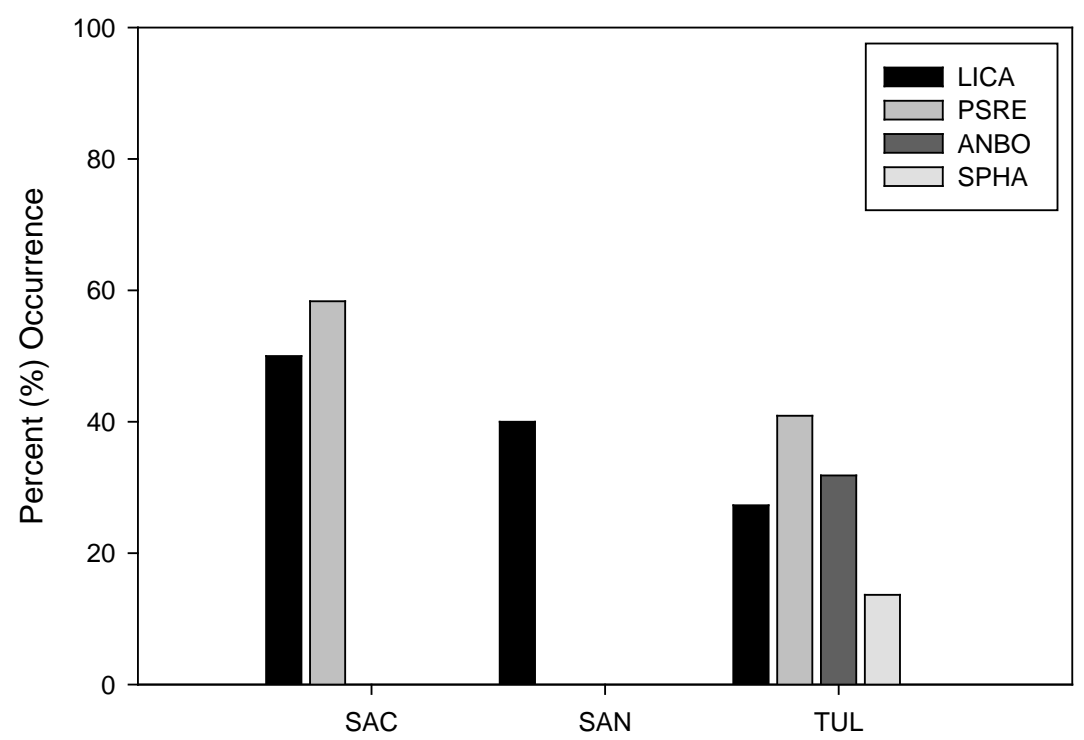

Figure G2. Percent occurrence of amphibian species recorded on selected WRP easements in 2008 by subbasin. SAC $=$ Sacramento, SAN $=$ San Joaquin, and TUL = Tulare. ANBO = western toad; $P S R E=$ Pacific chorus frog; LICA = American bullfrog; SPHA = western spadefoot toad.

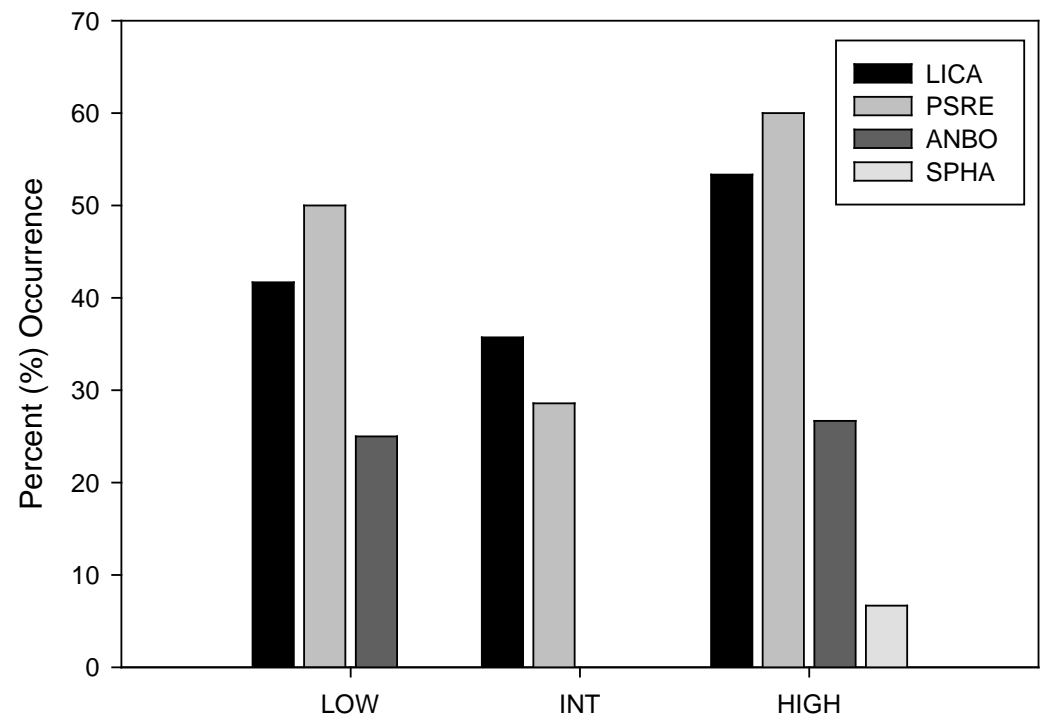

Figure G3. Percent occurrence of amphibian species recorded on selected WRP easements in 2008 by management intensity. LOW = sites under low or no management, INT = sites under intermediate management, $\mathrm{HIGH}=$ actively managed sites. $\mathrm{ANBO}=$ western toad; PSRE = Pacific chorus frog; $\mathrm{LICA}$ = American bullfrog; SPHA = western spadefoot toad. Management intensity categories are defined in appendix I, table I3. 


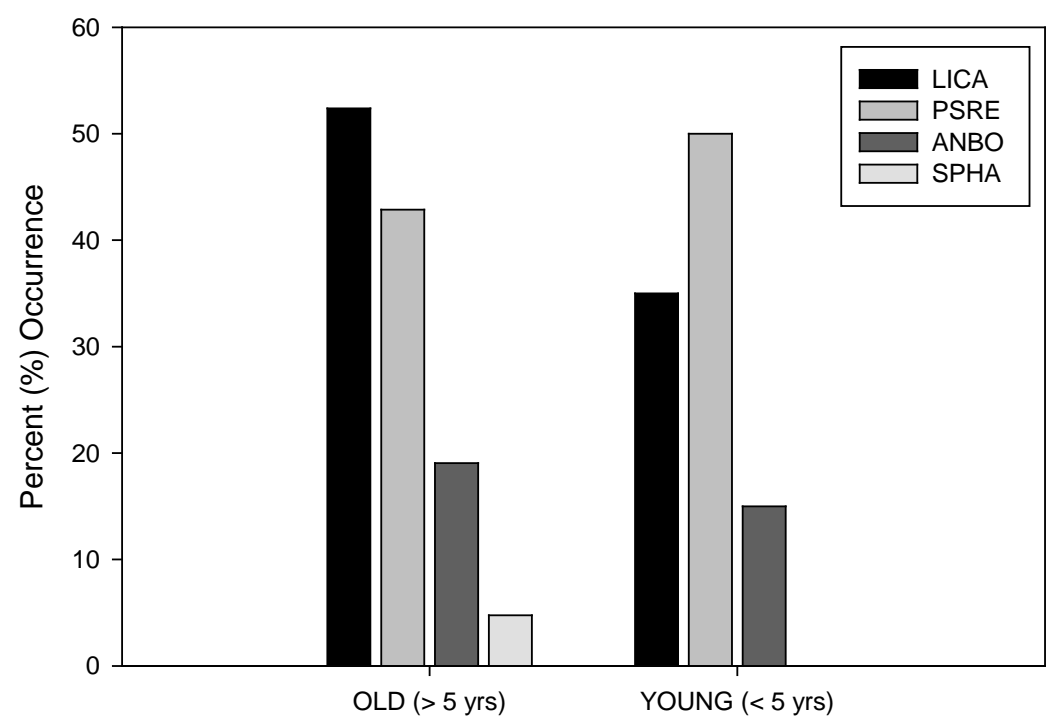

Figure G4. Percent occurrence of amphibian species recorded on selected WRP easements in 2008 by WRP age. ANBO = western toad; $P S R E=$ Pacific chorus frog; LICA = American bullfrog; SPHA = western spadefoot toad.

\section{Case Study: Effect of Managed Flooding Regimes on the Breeding Phenology of Western Spadefoot Toads (Spea hammondii) in Kern County, California}

\section{Introduction}

The western spadefoot toad, Spea hammondii, ranges from northern California to northwestern Baja California, Mexico. In California, this species occurs throughout the Central Valley and associated foothills, as well as the Coast Ranges and coastal lowlands between San Francisco and northwestern Mexico (U.S. Fish and Wildlife Service, 2005). The western spadefoot toad is a Species of Special Concern in California, as populations have been heavily impacted by agricultural practices, urban development, and the introduction of nonnative predators. For example, more than 80 percent of historically occupied $S$. hammondii habitat in southern California, and more than 30 percent in northern and central California, has been developed or converted to uses that are unsuitable for sustained populations (Jennings and Hayes, 1994). 
As a desert-adapted and opportunistic breeding species, S. hammondii synchronizes its reproduction with infrequent and unpredictable rainfall (Denver, 1998). Western spadefoot toads remain dormant in subterranean burrows for 8-10 months each year and typically emerge to breed with the onset of warm rains between January and March; however, individuals also may emerge anytime between October and April if favorable environmental conditions exist (Jennings and Hayes, 1994; Stebbins, 2003).

Like most anurans, spadefoot toads rely heavily on vocalization as their primary means of communication. Particularly, males produce a hoarse, snore-like call lasting approximately 0.5-1 s (Stebbins, 2003). These vocalizations are loud and distinct, which facilitates aural surveys using automated recording systems. The detection of species-specific calls provides relatively efficient mechanisms for studying and evaluating the status of anuran populations (Dorcas and others, 2009).

Generally, conservation practices and programs, such as the WRP, are intended to protect, restore, and enhance habitat and are assumed to benefit wildlife. Although such conservation efforts are designed to support wildlife or provide ecosystem services, the effects on wildlife are not entirely clear. Conservation efforts can have both positive and negative effects on species. For example, a question relevant to lands enrolled in the WRP might be "Can managed flooding regimes, regulated by landowners or managers, impact the reproductive phenologies of aquatic breeding species?” To address this question, we deployed aural recorders at three wetlands with 2000 or 2001 WRP enrollment dates ranging between 197 and 370 ha in size. The objectives of this study were to assess whether or not $S$. hammondii individuals shift breeding patterns to correspond with unnatural flooding events, and to determine the optimal time to detect vocalizing males.

\section{Methods}

We deployed four SM1 Song Meters (Wildlife Acoustics, Inc., Concord, MA, USA) at three adjacent WRP wetlands in Kern County, California, between May and August 2009 to assess the frequency and temporal variation of $S$. hammondii vocalizations (fig. G5). Specifically, one Song Meter was deployed at Site A, one meter was deployed at Site B, and two meters were deployed at Site C. Recorder locations were selected based on species observations from 2008 and the presence of suitable habitat, but were modified throughout the monitoring period to maintain close proximity to inundated areas. Nearly all land within $5 \mathrm{~km}$ of the study area is extensively cultivated and supports a variety of crops under irrigation; however, the U.S. Fish and Wildlife Service’s Wetlands Mapper (www.fws.gov/wetlands/Data/Mapper.html) identifies freshwater emergent, freshwater pond, and lake habitats approximately $4 \mathrm{~km}$ east and southeast of the sites (U.S. Fish and Wildlife Service, 2010).

With the exception of a single meter at Site C, we programmed all Song Meters to record the first 20 min of each hour between 2000 and 0200 (2000-2020, 2100-2120, and so forth). Western spadefoot toad vocalizations were detected at least $206 \mathrm{~m}$ from the calling male under conditions with very little ambient noise. Accordingly, we staggered the recording times of Song Meter \#2 at Site C to record the second 20-min interval of each hour (2020-2040, 2120-2140, and so forth) to avoid recording repeat vocalizations. Following the monitoring period, we reviewed the first 5 min of each recording (2000-2005, 2100-2105, and so forth) at a standardized volume. If the first 5 min were inaudible, due to wind or bird clamor for example, we reviewed the second 5-min interval (2005-2010, 2105-2110, and so forth). All S. hammondii vocalizations were tallied. 


\section{Results}

No western spadefoot toad vocalizations were recorded at Site A or B; however, vocalizations were recorded at Site $C$ during 63 evenings over the 124-day monitoring period. Particularly, calling males were detected during three distinct intervals (fig. G6). The first of these calling intervals began prior to the start of our study, while the others began on June 13 and July 10. The number of vocalizations per evening ranged from 4 to $1,259(\bar{x}=284, s=281)$ during times when males were calling. Overall, more vocalizations per hour were tallied from Song Meter 1 than Song Meter 2, but both meters recorded the greatest frequency of vocalizations during the 2100 sample (fig. G7). The average number of vocalizations per hour also was greatest during the 2100 sample for both Song Meters (fig. G8). We performed a oneway ANOVA test on the data collected from both Song Meters and found the average number of vocalizations per hour to be significantly different among hourly samples $(F=13.83, P=0.000$ and $F=6.75, P=0.000$, respectively).

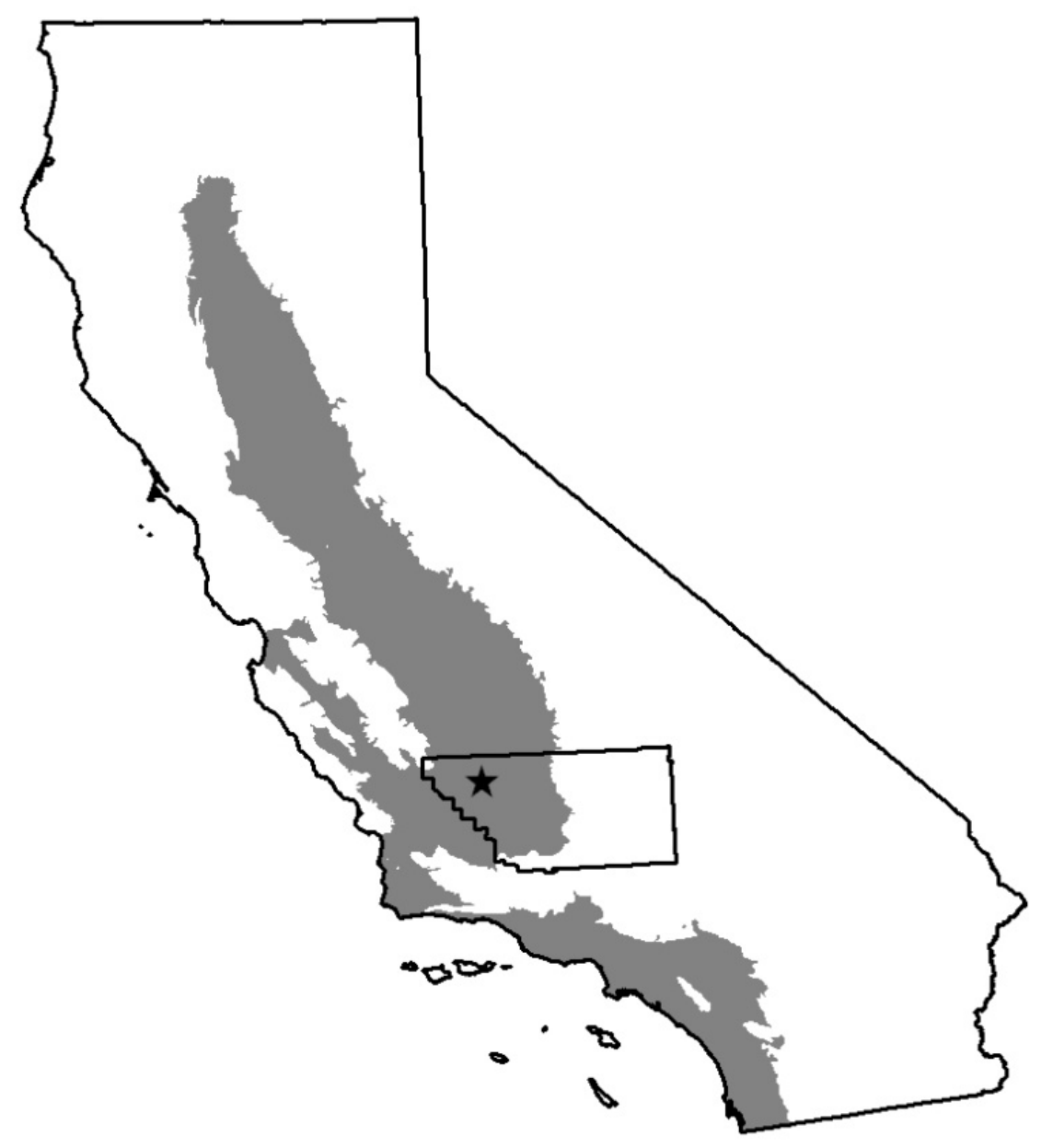

Figure G5. Spea hammondii geographic range in California indicated with gray shading. Location of study denoted with star symbol in Kern County, California, May through August 2009. 


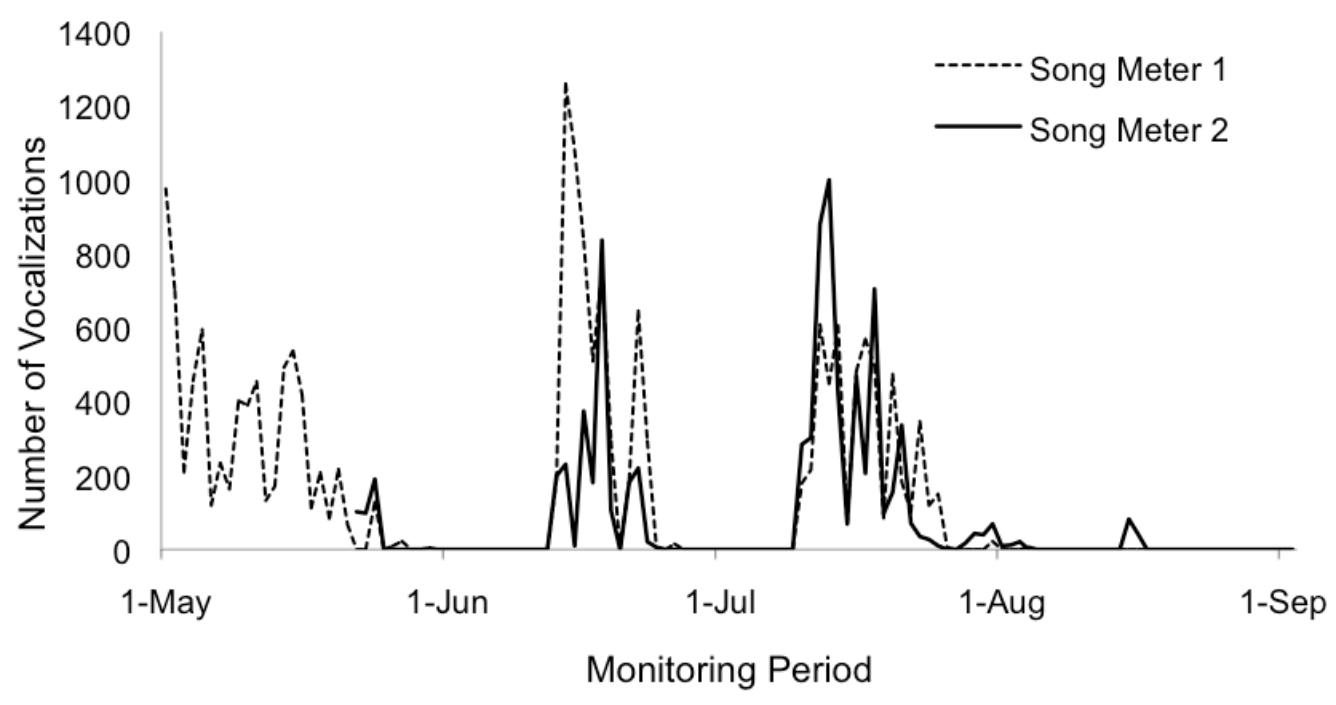

Figure G6. Frequency of Spea hammondii vocalizations per evening at Site C in Kern County, California, May through August 2009.

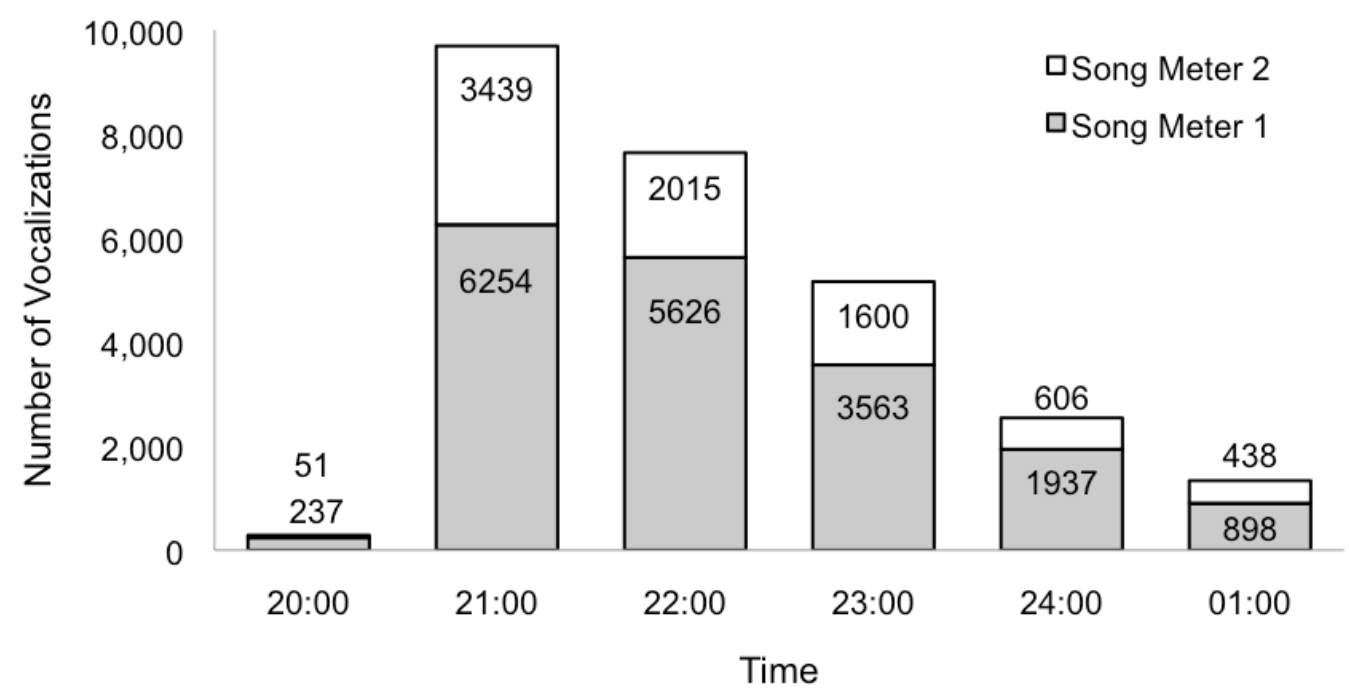

Figure G7. Frequency of Spea hammondii vocalizations per hour at Site C in Kern County, California, May through August 2009. 


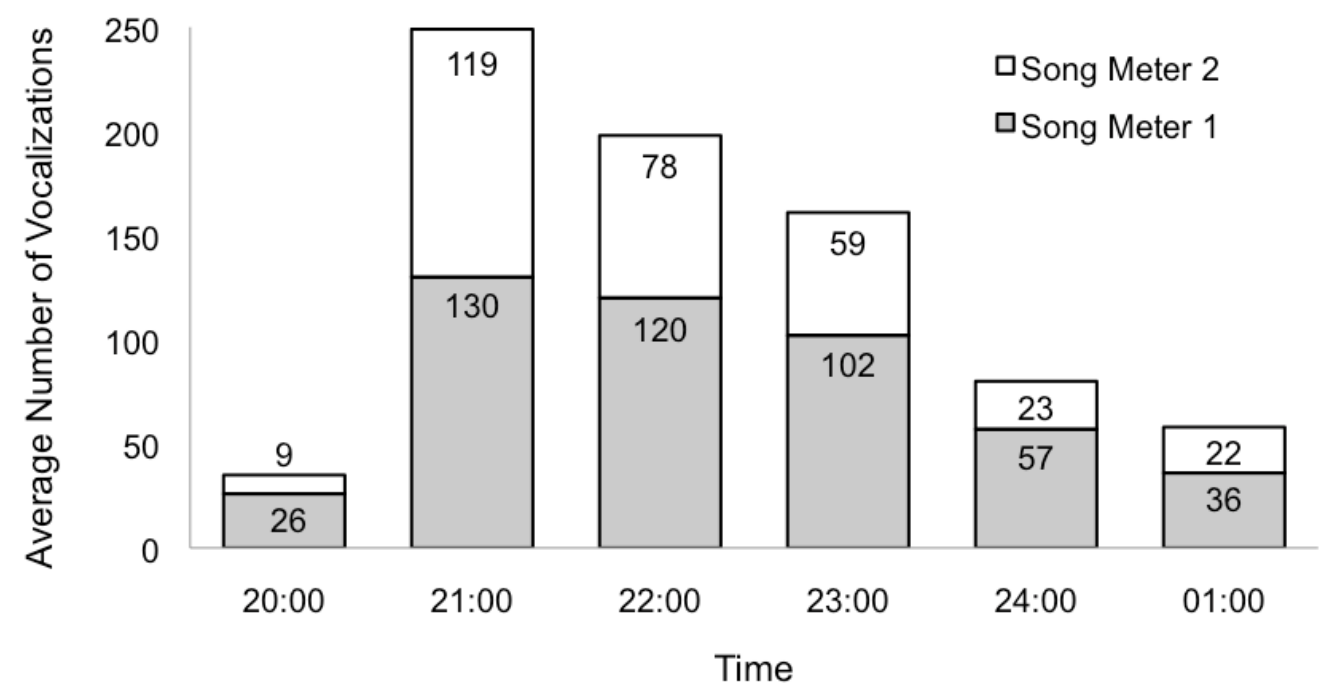

Figure G8. Average number of Spea hammondii vocalizations per hour at Site C in Kern County, California, May through August 2009.

\section{Discussion}

Our results indicate that male $S$. hammondii adults called most frequently between 2100 and 2200, but also were quite vocal between 2200 and 2400. Although the detection of $S$. hammondii larvae on July 1 confirms successful breeding at Site C, the timing of these reproductive bouts contradicts the primary literature. For example, Morey (2005), citing six primary literature articles, indicated that breeding is most likely to occur during February and March. Typically, the surface activity of this species decreases during the unbroken hot, dry periods of summer, with individuals becoming quiescent in their burrows by late summer (Morey, 2005). This was not the case for the population we monitored. We suspect that the deviation in breeding phenology at Site $\mathrm{C}$ is associated with the managed flooding regime practiced at the study area.

We cannot determine the exact mechanism that lured the western spadefoot toads from their burrows to breed, as our study was not designed to do so, but we suspect that flooding practices, rather than rainfall, triggered breeding. Although spadefoot toad reproduction is highly dependent on temperature and rainfall patterns, the primary emergence cue appears to be low frequency noise, such as the sound of rainfall (Dimmitt and Ruibal, 1980; Jennings and Hayes, 1994). Importantly, Dimmitt and Ruibal replicated this sound with an off-balance electric motor and successfully lured spadefoot toads from their burrows. Inundation of the study sites began in mid-April and ended in late August. Particularly, flooding was performed using a low-lift electric pump between April 20 and June 14; the pump ran nearly continuous during this period. 
After June 14, flooding was performed using a gravity feed system. Water remained on the sites throughout most of September. Several sources of low frequency noise were associated with these flooding events, including the low-lift electric pump, located approximately 1,500 $\mathrm{m}$ from Site C, and the water control structures used to deliver and divert water. These structures generate noise as water cascades between canals, channels, and wetlands. According to the National Oceanic and Atmospheric Administration's historical precipitation records, rainfall occurred on 3 days during the 124-day monitoring period. Specifically, $8.9 \mathrm{~mm}$ were reported on May 2, $0.8 \mathrm{~mm}$ on June 5 and $0.8 \mathrm{~mm}$ on June 6 .

Our results show that $S$. hammondii males vocalize most frequently between 2100 and 2400 and that automated recording systems are effective at detecting chorusing populations. We do not advise conducting aural surveys outside this time period. Manual surveys efforts constrained by time or money should be concentrated between 2100 and 2200, as we have demonstrated that $S$. hammondii males vocalize most frequently during this period. Our research focused on documenting S. hammondii's ability to shift its breeding phenology to correspond with managed, or unnatural, flooding events; however, other species and taxa also are likely to be impacted by such practices. Further research aimed at investigating how multiple species within biological communities respond to manipulated flooding regimes in managed wetlands would be helpful to wetland managers. 
This page left intentionally blank 


\title{
Chapter H: Pollinators in Wetlands Reserve Program (WRP) Habitats in the California's Central Valley (CCV)
}

\author{
By Kim McFarland and Sharon N. Kahara, Humboldt State University
}

\section{Introduction}

Crop pollination is a critical ecosystem service delivered by foraging activities of mobile organisms. In the United States, 30 percent of food production depends on animal based crop pollination services and is estimated at 5-14 billion dollars annually (McGregor, 1976; Kremen and others, 2007).

Pollination services are provided by both free-living organisms such as native bees, butterflies, moths, birds and mammals, as well as commercially managed European honey bees (Apis mellifera). Recently, managed honey bee populations have declined precipitously as a result of diseases, pests and improper use of pesticides and herbicides. This has raised concern over pollinator service shortfalls, particularly in the CCV where most of North America's pollinator dependent crops are grown.

Under the right conditions, native pollinators may provide equivalent pollination services to those of managed bee populations. In addition, biodiversity may be an important component in maintaining pollination services given population fluctuations among species from year to year (Kremen and others, 2002).

Pollination activity depends on a number of factors ranging from the individual organism behavior to community dynamics. These factors are in turn affected by the distribution of food resources and land use. Loss of food resources and nesting areas due to fragmentation of natural and semi-natural habitat can limit native bee populations in agricultural landscapes (Klein and others, 2007).

Non-cultivated areas may provide refugia for native bee populations, however, effects of conservation practices on bee abundance and diversity are unknown. The objective of this study was to assess WRP easements' support of pollinators along three major gradients; restoration age, subbasins, and management intensity.

\section{Methods}

In 2008, native bees were sampled at 35 WRP properties and two NWR with three units sampled at each NWR. Sites were sampled once between March and early June, except for three NWR units, which were sampled three times during this interval (once in March and twice in April). In 2009, native bees were sampled three to five times, approximately once every 4 weeks from late February to early June, at 16 WRPs and three units at one NWR. Three WRP were sampled at least once at an alternate nearby site due to temporary access issues for a total of 19 WRP sites sampled 1-5 times during the season.

A 1-ha sampling plot was established within each bee sampling site. Plots were located on levee banks and dry upland or moist meadows within the bee sampling site where flowering plants used by bees are found. Efforts were made to maintain at least $2 \mathrm{~km}$ distance between sampling plots, particularly where bee sampling sites were in close proximity. 
Bee collection methods consisted of passive pan trapping and active collection with aerial nets at floral resources. Thirty pans (Solo brand B200-0100 2 oz. / 57 g soufflé portion cups, Solo Cup Co., Lake Forest, IL) were placed along two 50-m long transects, spaced at 5-m intervals. Ten pans were painted fluorescent yellow (Ace Glo Spray Fluorescent, Solar Yellow 17052/17052A, Ace Hardware Corp., Chicago, IL), 10 fluorescent blue (Ace Glo Spray Fluorescent, Blue 19716/19716A), and 10 were painted white (Krylon Fusion, 2320 Gloss White, Krylon Products Group, Cleveland, $\mathrm{OH}$ ).

Pans were filled with a solution of one generous squirt of Dawn (Soap.com, Jersey City, $\mathrm{NJ}$ ) brand dish blue soap per 3.8 L of tap water, set in place before $0900 \mathrm{~h}$ and collected the same day after 1500 h. Pan trapped specimens were stored by sample plot in Whirlpak (Nasco Corp., Salida, CA) bags in a 70 percent ethyl alcohol solution until processing and identification at Humboldt State University. For $1 \mathrm{~h}$ in the morning and $1 \mathrm{~h}$ in the afternoon, one person netted all flowers in the 1-ha plot. Bee surveyors took care to cover all areas of the plot with equal effort and record the flower from which each specimen was collected. Bees collected at flowers were pinned the same day and brought to Humboldt State University for identification.

A GPS reading was taken at the approximate center of each plot with a Garmin GPS 12 (minimum accuracy of $\pm 15 \mathrm{~m}$ ). Percent cover of flowers in bloom was estimated using the Braun-Blanquet relevé method (California Native Plant Society, 2004). A Kestrel ${ }^{\circledR}$ weather station (model 3000, KestrelMeters.com, Sylvan Lake, MI) was used to record temperature, relative humidity, and wind speed.

\section{Results and Discussion}

A census of bee pollinators was conducted in the spring and summer 2008. Of more than 20,000 individuals captured by pan trapping and netting, about 71 percent were classified as native bees and 29 percent were honey bees. Bees were collected on more than 50 flowering plants. The highest number of bees (native and honey) was captured on black mustard flowers (Brassica nigra) (table H1).

Our results showed that all bees (native and honey) and native bees were significantly more abundant in the Tulare subbasin (figs. H1 and H2). Native bees were significantly correlated with average upland area (fig. H3). All bees and native bees were significantly less abundant in intermediately managed sites, however no significant differences were detected between low and actively managed sites (figs. H4 and H5).

Remaining 2008 samples will be identified to genus by a Humboldt State University Masters student. Identification of 2008 specimens is 75 percent complete, with 19,833 specimens identified to genus. All 2009 specimens have been processed and pinned and will be identified and curated. Data analysis on these remaining specimens is pending.

\section{Current Status and Recommended Approach}

U.S. Department of Agriculture conservation programs hold immense potential for wildlife. Reports indicate positive impacts particularly for waterfowl and upland birds (for example, Central Valley Joint Venture, 2006a; King and others, 2006, Laubhan and others, 2008). However, socio-economic services provided by non-game wildlife are often undervalued. 
In the case of pollinators, their economic value to agricultural landscapes such as the CCV is well known. It is estimated that pollinators are critical in 35 percent of global crop production. More than 80 percent of wild plants may benefit from animal visitation (Kremen and others, 2007). Despite this, agricultural intensification poses threats to native pollinators. Habitat fragmentation, conversion to crops that do not support animal pollinators and management practices that negatively impact nesting sites are some of the problems facing native pollinators in the CCV.

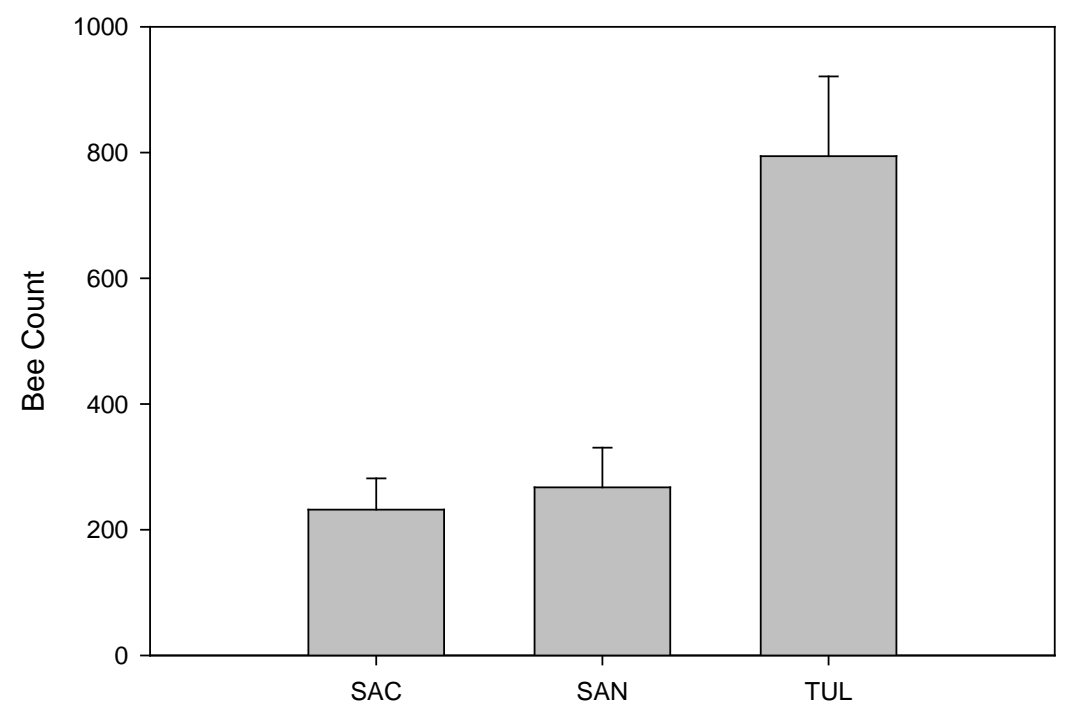

Figure H1. Average number of bees (native and honey) collected at 39 WRP easements in California's Central Valley in 2008, by subbasin. SAC = Sacramento, SAN = San Joaquin, and TUL = Tulare. Bars are standard errors. 


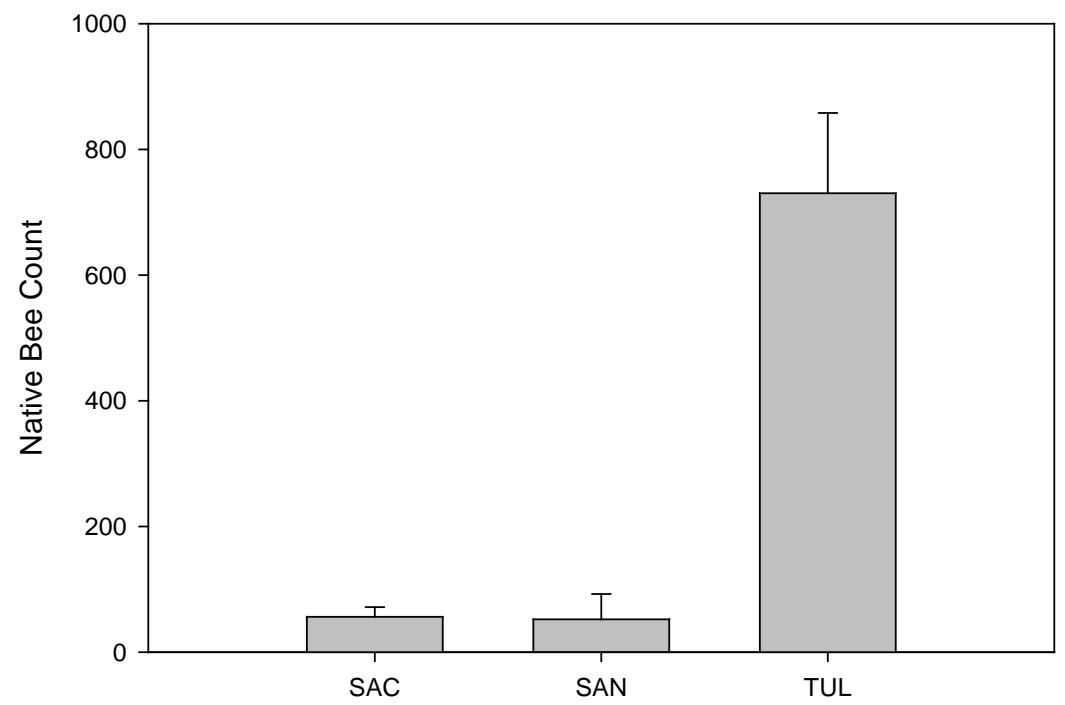

Figure H2. Average number of native bees collected at 39 WRP easements in California's Central Valley in 2008, by subbasin. SAC = Sacramento, SAN = San Joaquin, and TUL = Tulare. Bars are standard errors.

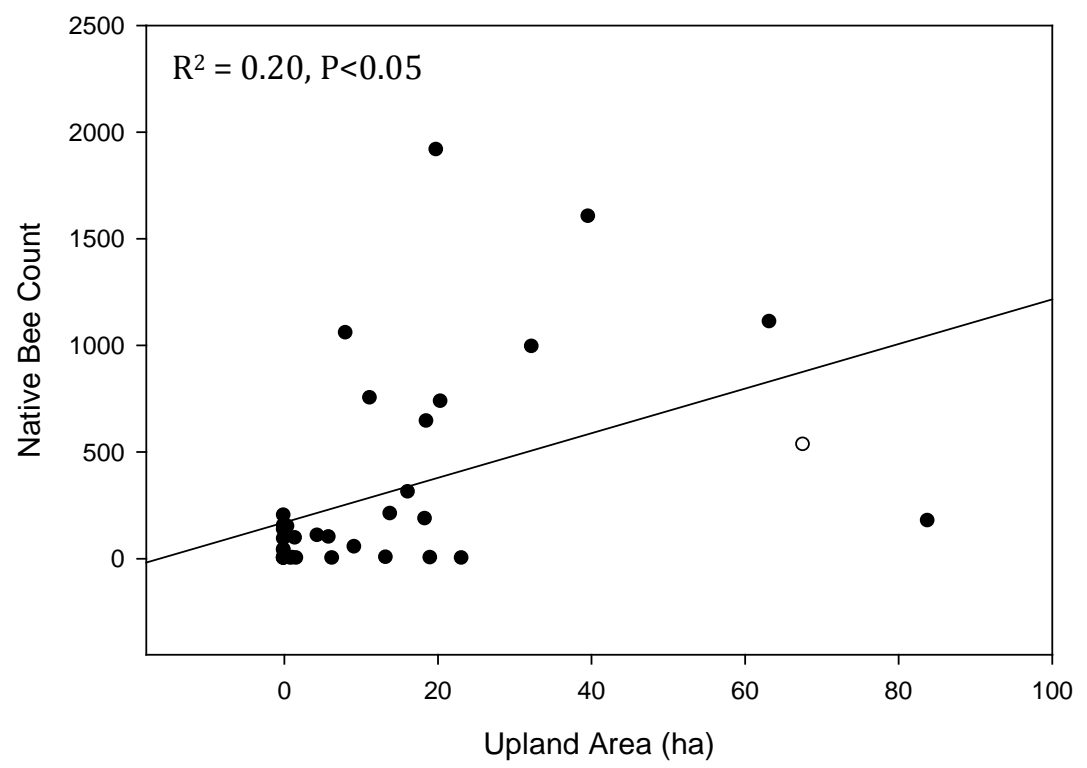

Figure H3. Upland area versus native bee counts. Bees were collected at 39 WRP easements in California's Central Valley in 2008. 


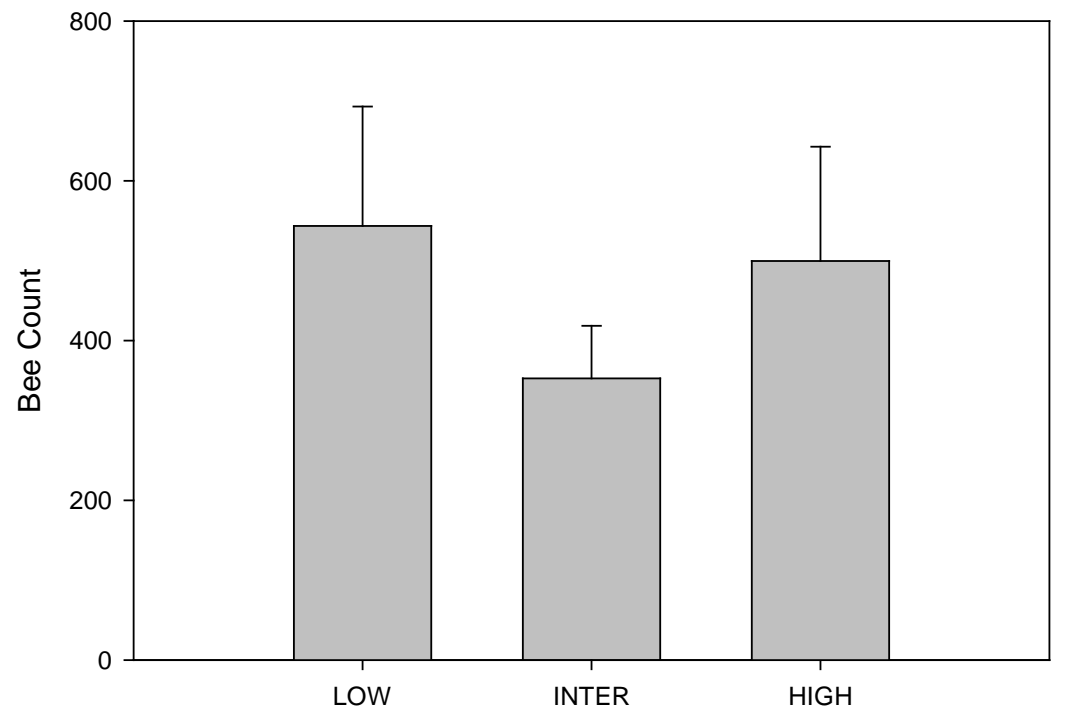

Figure H4. Average number of bees collected at 39 WRP easements in California's Central Valley in 2008 , by management intensity. LOW = sites under low or no management, INTER = sites under intermediate management, $\mathrm{HIGH}=$ actively managed sites. Bars are standard errors.

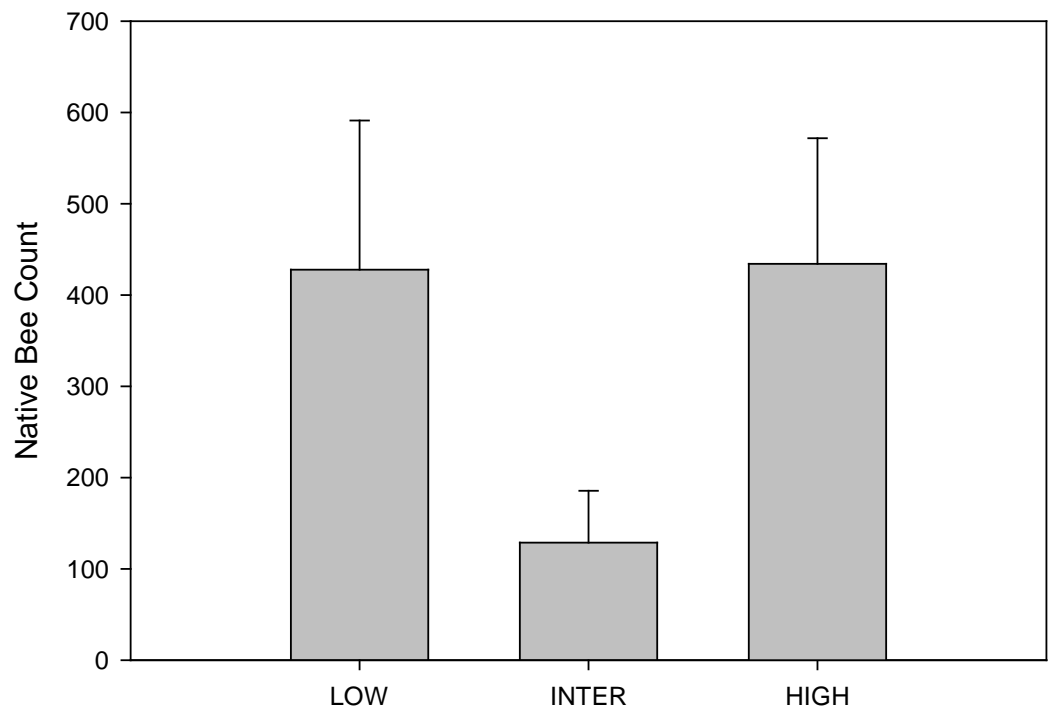

Figure H5. Average number of native bees collected at 39 WRP easements in California's Central Valley in 2008 , by management intensity. LOW = sites under low or no management, INTER = sites under intermediate management, $\mathrm{HIGH}=$ actively managed sites. Bars are standard errors. 
Table H1. Abundance of native and honey bees (Apis mellifera) collected in California's Central Valley (March-May 2008) and associated flowering plants.

\begin{tabular}{|c|c|c|c|c|c|}
\hline Family & Genus & Specific epithets & Common Name & $\begin{array}{l}\text { Native } \\
\text { bees }\end{array}$ & $\begin{array}{c}\text { Honey } \\
\text { bees }\end{array}$ \\
\hline & & & Western & & \\
\hline Aizoaceae & Sesuvium & verricosum & sea-purslane & 11 & 2 \\
\hline Apiaceae & Conium & maculatum & Poison hemlock & 8 & 57 \\
\hline Apiaceae & Torilis & arvensis & Torilis & 1 & 0 \\
\hline Asclepoadaceae & Asclepias & spp. & Milkweed & 0 & 3 \\
\hline Asteraceae & Anthemis & cotula & Stinkweed & 39 & 206 \\
\hline Asteraceae & Centaurea & colstitialis & Yellow star-thistle & 7 & 6 \\
\hline Asteraceae & Chicorium & intybus & Chickory & 30 & 74 \\
\hline Asteraceae & Cirsium & $\begin{array}{l}\text { vulgare } \\
\text { pungens ssp. }\end{array}$ & Bull thistle & 1 & 26 \\
\hline Asteraceae & Hemizonia & pungens & Common spikeweed & 8 & 0 \\
\hline Asteraceae & Lasthenia & spp. & Goldfields & 122 & 228 \\
\hline Asteraceae & Picris & echoides & Oxtongue & 0 & 1 \\
\hline Asteraceae & Silybum & marianum & Blessed milk thistle & 27 & 138 \\
\hline Asteraceae & Sonchus & arvensis & Perennial sow thistle & 10 & 0 \\
\hline Asteraceae & Taraxacum & officinale & Dandelion & 3 & 0 \\
\hline Boraginaceae & Amsinkia & spp. & Fiddleneck & 8 & 1 \\
\hline Boraginaceae & Heliotropium & curassavicum & Heliotrope & 6 & 0 \\
\hline Brassicaceae & (unknown) & spp. & Mustard & 17 & 56 \\
\hline Brassicaceae & Brassica & nigra & Black mustard & 125 & 3043 \\
\hline Brassicaceae & Capsella & bursa-pastoris & Shepard's purse & 1 & 0 \\
\hline Brassicaceae & Lepidium & latifolium & Pepperwort & 1 & 55 \\
\hline Brassicaceae & Raphanus & sativus & Radish & 56 & 269 \\
\hline Brassicaceae & Sinapis & arvensis & Charlock & 98 & 47 \\
\hline Brassicaceae & Sisymbrium & altissimum & Tumble mustard & 54 & 0 \\
\hline Brassicaceae & Sisymbrium & irio & London rocket & 67 & 1 \\
\hline Caryophyllaceae & Silene sp. & spp. & Campion & 13 & 29 \\
\hline Caryophyllaceae & Spergularia & macrotheca & Sand-spurrey & 4 & 0 \\
\hline Convolvulaceae & Convolvulus & arvensis & Bindweed & 103 & 92 \\
\hline Convolvulaceae & Cressa & truxillensis & Alkali weed & 1 & 0 \\
\hline Fabaceae & Astragalas & spp. & Milkvetch & 1 & 0 \\
\hline Fabaceae & Lotus & corniculatus & Birdfoot trefoil & 49 & 302 \\
\hline Fabaceae & Melilotus & alba & White sweetclover & 5 & 32 \\
\hline Fabaceae & Melilotus & indica & Sourclover & 125 & 91 \\
\hline Fabaceae & Trifolium & fragiferum & Strawberry clover & 0 & 4 \\
\hline Fabaceae & Vicia & benghalensis & Vetch & 1 & 0 \\
\hline Fabaceae & Vicia & villosa ssp. varia & Hairy vetch & 46 & 2 \\
\hline Geraniaceae & Erodium & circulatum & Red stem filaree & 11 & 4 \\
\hline Geraniaceae & Erodium & spp. & Erodium & 1 & 0 \\
\hline Hydrophyllaceae & Nemophila & menziesii & Baby blue-eyes & 0 & 0 \\
\hline
\end{tabular}


Table H1. (concluded).

\begin{tabular}{llllcc}
\hline \multicolumn{1}{c}{ Family } & \multicolumn{1}{c}{ Genus } & Specific epithets & \multicolumn{1}{c}{ Common Name } & $\begin{array}{c}\text { Native } \\
\text { bees }\end{array}$ & $\begin{array}{c}\text { Honey } \\
\text { bees }\end{array}$ \\
\hline Hydrophyllaceae & Phacelia & ciliate & Valley pacelia & 109 & 3 \\
Lamiaceae & Marrubium & vulgare & Horehound & 3 & 1 \\
Lamiaceae & Mentha & pulegium & Pennyroyal & 2 & 27 \\
Lamiaceae & Stachys & ajugoides & Hedge nettle & 1 & 0 \\
Liliaceae & Brodiaea & elegans ssp. & Harvest brodiaea & 2 & 0 \\
& & elegans & Loosestrife & 7 & 7 \\
Lythracea & Lythrum & hyssopifolium & Alkali-mallow & 1 & 9 \\
Malvaceae & Malva & leprosa & Cheeseweed & 7 & 4 \\
Malvaceae & Malva & parviflora & Willow herb & 1 & 0 \\
Onagraceae & Epilobium & densiflorum & Plantain & 0 & 1 \\
Plantaginaceae & Plantago & spp. & Dock & 0 & 2 \\
Polygonaceae & Rumex & crispus & Dock & 1 & 0 \\
Polygonaceae & Rumex & pulcher & California rose & 3 & 24 \\
Rosaceae & Rosa & californica & Rose & 5 & 62 \\
Rosaceae & Rosa & spp. & Himalayan blackberry & 7 & 65 \\
Rosaceae & Rubus & discolor & Rubus & 5 & 157 \\
Rosaceae & Rubus & spp. & Willow & 46 & 26 \\
Salicaceae & Salix & spp. & Phyla & 6 & 79 \\
Verbenaceae & Phyla & lanceolata & & & \\
\hline
\end{tabular}

Kremen and others (2004) determined the area requirements for native pollinators by generating a model relating units of pollen deposited on watermelon flowers by upland habitat area. They defined upland habitat as areas of oak, mixed oak, and chaparral. The models developed found a strong positive linear relationship between pollination services and area of upland habitat within 1-2.5 km of surveyed farm sites. In a conceptual model developed by Kremen and others (2007), the abundance of wild pollinators is influenced by biotic and abiotic factors affecting both pollinator populations and floral resource availability. Land use practices at each site affect local plant and pollinator composition, and these effects aggregate to the landscape level. Landscape structure affects the spatial and temporal availability of food, nesting sites, overwintering and mating sites.

We suggest implementing a simpler version of their model to quantify suitability of available habitats in the CCV, and determine whether USDA conservation programs including Conservation Reserve Program (CRP) lands provide enhanced habitat for native pollinators. The model would estimate pollinator service delivery within an agricultural landscape as the interaction between flowering plant availability and presence of suitable pollinator nesting habitat within adequate range $(1-2.5 \mathrm{~km})$.

At the site level, increased agricultural intensity can increase mortality through pesticide use, practices such as disking, flood irrigation and removal of woody vegetation, which can reduce nesting site quality. Alternatively at the landscape scale, intensive agriculture may introduce more pollinator dependent crops such as melons, sunflowers, and almonds that may increase available food resources. However, monocultures may result in fewer available 
resources for a variety of pollinator species leading to lower pollinator biodiversity. Distance and quantity of adequate food sources in the surrounding landscape also can impact pollinator presence and abundance. Hedgerows between fields, presence of fallow fields and meadows as well as woody vegetation can boost pollinator abundance and increase access to more desirable food resources. Maintaining flower rich margins and levees with annual weed communities may serve as corridors. Land use policies and management may affect availability and abundance of floral resources by influencing which crops are grown and whether land is retired from production. Incentive programs, such as WRP and CRP, influence management practices and availability of wild floral resources. Patches of bare ground with soils of differing textures and provision of artificial nest holes drilled in boards or branches can serve as adequate habitat substitutes for some species at the site level (fig. H6).

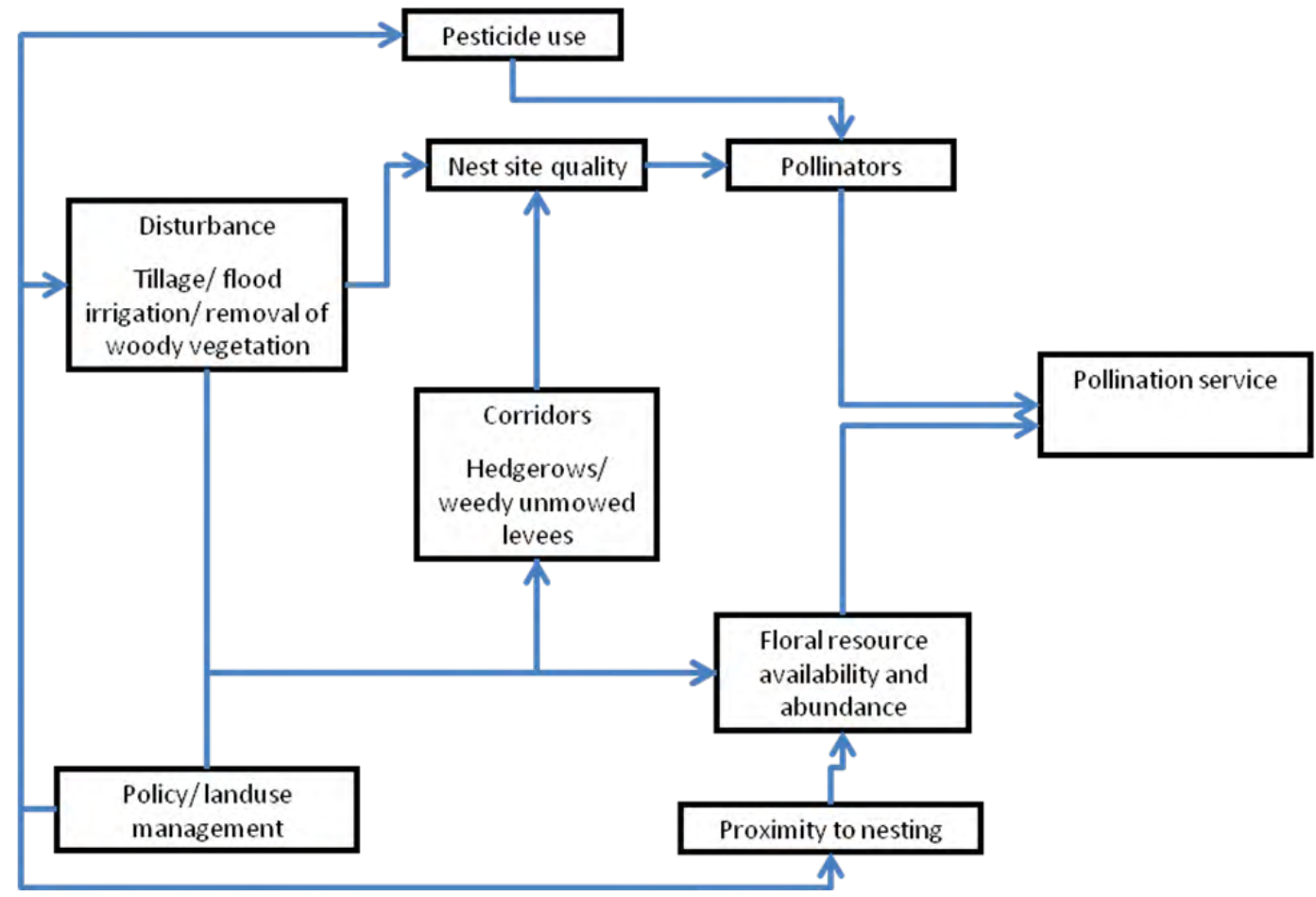

Figure H6. Conceptual model describing impacts of site specific and landscape level changes on pollinator services. Arrows indicate effect (adapted from Kremen and others, 2007). 
We recommend further research into pollinator diversity on WRP easements, including:

1. Continued monitoring for native bees on conservation easements using standardized methods (as used in this report and available online at http://online.sfsu.edu/ beeplot/, LeBuhn and others, 2003).

2. Additional research on the effects of pesticides (herbicides and insecticides) on native bees for WRP units adjacent to croplands.

3. Empirical studies of the effectiveness of pollination services provided by native bees in agricultural lands in proximity to WRP properties looking specifically at seed and fruit set as corresponding to native bee visitation rates.

4. Investigation into the natural history of native bee species that occur in the Central Valley, including nesting biology, floral resource use, and phenology. Much of this information is still largely lacking for the Central Valley (Allen-Wardell and others, 1998). 
This page left intentionally blank 


\title{
Chapter I: Wetlands Reserve Program (WRP) Habitat Assessment in the Upper Klamath River Basin (UKRB)
}

\author{
By Walter G. Duffy, U.S. Geological Survey
}

\section{Introduction}

The Upper Klamath River Basin encompasses of 2.3 million ha in northern California and southern Oregon, and is located within the southern Cascade physiographic region. Although the basin includes Crater Lake and surrounded by mountains, much of the area east and south of Upper Klamath Lake is relatively flat and less than 1,600 m elevation. Primary subbasins within the area include those draining Wood, Williamson, Sprague, and Lost Rivers.

Palustrine emergent wetlands once covered expansive areas in this region, but most have been converted to agricultural lands (National Research Council, 2007). These included extensive freshwater marshes around Upper Klamath Lake and riparian wetlands adjacent rivers and tributaries. Unlike wetlands in the CCV, existing wetlands in the UKRB reflect more of the historical condition of the basin and restored wetlands typically are not actively managed.

We assessed habitat characteristics and nutrient storage of WRP easements in the UKRB to compare with more numerous CCV WRP sites.

\section{Site Selection}

Site selection of easements in the Upper Klamath River Basin (UKRB) was constrained by the number of WRP easements available. Furthermore, we wished to assess fish use of WRP easements in this region, which further constrained site availability. In 2008, we surveyed amphibians in nine WRP easements (sites UKRB-2 and UKRB-4 to -11) in the UKRB, assessed potential fish access to these WRPs, and conducted vegetation habitat assessment on two of the nine easements. In 2009, we sampled three riparian WRP easements along the Sprague River, site UKRB-4 that had been identified in 2008 and sites UKRB-1 and -3 (fig. 5). The limited number of WRP easements in this region precluded stratifying sampling across management intensity, restoration age and precipitation gradients. Data collection was conducted during April-July 2008, March-June 2009, and March-June 2010.

Most of the wetlands we sampled on WRP easements in the UKRB had a seasonal hydroperiod that included flooding in the winter or spring and drying in the summer and fall. Within this regime, however, portions of these wetlands had more of a semi-permanent hydroperiod, retaining water into the summer or fall. Most of the wetlands we sampled were unmanaged. Exceptions included sites UKRB-3 and -4, where some water management occurred via water control structures opened in spring to allow riparian flooding. All wetlands we sampled in the UKRB also were relatively young, $\leq 5$ years since restoration activities were initiated (NB: Initial restoration dates should not be confused with date of establishment as the two do not always coincide. Typically, restoration activities begin several months after easement establishment). The relatively short period since completion of restoration is reflected in soil development and biological communities. 


\section{Methods}

Vegetation was surveyed and cover estimated at five wetlands in the UKRB during July 2008 (sites UKRB-9 and -10) and March 2009 (sites UKRB-1, -3, and -4). Restoration age at the five wetlands ranged from 1 to 5 years; being 1 year at site UKRB-1, 2 years at site UKRB-10, and 4-5 years at sites UKRB-3, -4 , and -9. Management of the wetlands varied. Sites UKRB-3 and -4 have received moderate management, consisting of water application, during recent years. Site UKRB-1 received no active management, while level of management at sites UKRB-9 and UKRB-10 was unknown. All wetlands surveyed were classified as having a seasonal hydroperiod.

Visual estimates derived for two wetland basins in the UKRB in 2008 (sites UKRB-9 and -10) and three wetland basins in 2009 (sites UKRB-1, -3, and -4) included the percentage of area covered by open water and emergent vegetation, wetland cover type, and adjacent land use. Detailed vegetation information was gathered following procedures developed by USGSNorthern Prairie Wildlife Research Center (Kantrud and Newton, 1996). One transect was established in each of four corners of the WRP property or corners of a cell. There was no fixed distance between transect locations. The size (meters) of all wetland vegetation zones, as delineated by plant species composition, bisected by transects was estimated and water depth (centimeters) recorded. Within each of these zones, a 1- $\mathrm{m}^{2}$ quadrat was randomly sited along each transect. Vegetation cover ( percent) by taxon (Daubenmire, 1959), litter depth (centimeters), and visual obstruction at plot center (Robel and others, 1970) were estimated. The limited sample size required all data to be assessed qualitatively.

\section{Results}

Predominant cover at four of the five wetlands was grasses (Poa spp.), and grasses comprised the overwhelming majority of cover at two sites (table I1). Tule (Schoenoplectus acutus) was predominant at site UKRB-10 where spikerush (Eleocharis spp.) also was common. Cattail (Typha spp.) covered 10-25 percent of the wetlands at four sites, but was absent from site UKRB-10. Willow (Salix spp.) was present at the three Sprague River riparian wetlands (sites UKRB-1, -3, and -4), but absent at the other two sites.

\section{Discussion}

Grasses dominated the cover in four of five wetlands surveyed during 2008 and 2009. The predominance of grasses in riparian habitats reflects natural conditions in UKRB, which historically consisted of a mosaic of grasslands, sagebrush, and mixed conifers. We observed grasses to be common throughout the lowlands, including non-WRP wetlands as well as WRP easement wetlands. The single site that we are aware of having received vegetation management was site UKRB-4, where vegetation management consisted of willow planting. The percentage of willow cover at this site was slightly higher than at sites UKRB-1 and -3, the other riparian WRP wetlands along the Sprague River. The vegetation cover at site UKRB-10 was different than at the other four wetlands sampled and was dominated by tule. This is undoubtedly the result of site UKRB-10 being young, $\leq 2$ years since restoration, and being managed for waterfowl habitat by Oregon Department of Fish and Game. 
Table 11. Percent cover by plant type and open water at five wetlands within WRP easements in the Upper Klamath River Basin during 2008.

\begin{tabular}{lccccccc}
\hline & \multicolumn{7}{c}{ Percent Cover } \\
\cline { 2 - 8 } Site & Grasses & Cattail & Sedge $^{1}$ & Spikerush & Tule & Willow & Open water \\
\hline UKRB-1 & 75 & 10 & 10 & 0 & 0 & 5 & 0 \\
UKRB-3 & 35 & 25 & 0 & 0 & 10 & 5 & 25 \\
UKRB-4 & 40 & 15 & 5 & 0 & 10 & 10 & 20 \\
UKRB-9 & 80 & 10 & 9.5 & 0 & 0 & 0 & 0.5 \\
UKRB-10 & 0 & 0 & 0 & 35 & 55 & 0 & 10 \\
\hline
\end{tabular}

${ }^{1}$ Sedges include several genera of Cyperaceae. 
This page left intentionally blank 


\title{
Chapter J: Wetlands Reserve Program (WRP) Soil Properties in the Upper Klamath River Basin (UKRB)
}

\author{
By Rosemary M. Records and Walter G. Duffy, U.S. Geological Survey
}

\section{Objective}

We sampled soils at WRP wetlands in the UKRB to characterize soil nutrient content.

\section{Methods}

Soil samples were collected in July 2009 at three WRPs in the UKRB (sites UKRB-1, -3, and -4). Samples were taken at corners of the WRP property as a whole or of (a) wetland cell(s) within the WRP. At each of three sampling locations, two cores were taken and bagged separately in plastic Ziploc ${ }^{\circledR}$ packets, for a total of six soil samples per WRP. The first core was taken to a depth of approximately $1 \mathrm{~cm}$. The depth of the second core ranged from 16.4 to 24.9 $\mathrm{cm}$, depending on ease of auguring the sample.

The following soil parameters were measured: litter depth, total carbon, total nitrogen, total $\mathrm{CaCO}_{3}$, total phosphorus, and bulk density. In the laboratory, all samples were weighed, dried at $101^{\circ} \mathrm{C}$ to a constant weight, and then re-weighed for bulk density determination. In 2009, samples were analyzed by the Agriculture and Natural Resources Laboratory of the University of California at Davis, California. Analysis of total N and total C was conducted according to methods in Association of Analytical Communities (1997). Total P was analyzed by acid dissolution followed by ICP analysis (Sah and Miller, 1992). Gravimetric determination of $\mathrm{CaCO}_{3}$ was carried out according to the methods in U.S. Department of Agriculture (1954). All soil samples were ground and sieved through a $2 \mathrm{~mm}$ sieve before analysis. The limited sample size required all data to be assessed qualitatively.

\section{Results}

Soil core depth was slightly shallower at site UKRB-1 than at sites -3 and -4, but was adequate to characterize litter depth. Soil litter depth ranged from 2.29 to $3.87 \mathrm{~cm}$ (table J1) and decreased from site UKRB-1 through site -3 .

Percentage of total nitrogen (TN), total carbon (TC), total phosphorus (TP), and $\mathrm{CaCO}_{3}$ decreased from site UKRB-1 through site -4. This pattern was consistent for both the upper $1 \mathrm{~cm}$ of soil and for the total core depth (table J2). Percentage of nutrients was about two times greater in the upper $1 \mathrm{~cm}$ of soil than in the entire core. The exception was $\mathrm{CaCO}_{3}$ at site UKRB-1, where replicate samples were lacking. 
Table J1. Average depth of soil cores and depth of litter in cores at three wetlands within WRP easements in the Upper Klamath River Basin.

[Averages are based on five measurements per core; numbers in parentheses are one standard deviation of the average]

\begin{tabular}{lllll}
\hline \multicolumn{1}{c}{ Site } & \multicolumn{2}{c}{ Core depth $(\mathbf{c m})$} & \multicolumn{2}{c}{ Litter depth (cm) } \\
\hline UKRB-1 & 18.85 & $(1.79)$ & 3.87 & $(1.80)$ \\
UKRB-3 & 23.75 & $(0.46)$ & 2.87 & $(1.20)$ \\
UKRB-4 & 23.47 & $(0.66)$ & 2.29 & $(2.09)$ \\
\hline
\end{tabular}

Table J2. Average percentage of total nitrogen (TN), total carbon (TC), total phosphorus (TP), and calcium carbonate $\left(\mathrm{CaCO}_{3}\right)$ in soil samples from about $20 \mathrm{~cm}$ deep core samples at three wetlands within WRP easements in the Upper Klamath River Basin.

[Composition of the upper $1 \mathrm{~cm}$ of cores at each site are presented separately. Averages are based on five measurements per core; numbers in parentheses are one standard deviation of the average]

\begin{tabular}{ccccc}
\hline \multirow{2}{*}{ Site } & TN ( percent) & \multicolumn{1}{c}{ TC ( percent) } & TP ( percent) & CaCO $_{3}$ ( percent) \\
\cline { 2 - 4 } & \multicolumn{4}{c}{ 1 cm depth core } \\
\hline UKRB-1 & $1.23(0.38)$ & $15.71(3.73)$ & $0.10(0.02)$ & $0.50(--)$ \\
UKRB-3 & $0.39(0.38)$ & $5.06(5.49)$ & $0.06(0.03)$ & $0.80(0.14)$ \\
UKRB-4 & $0.23(0.09)$ & $2.58(1.06)$ & $0.05(0.01)$ & $0.80(0.44)$ \\
\multicolumn{5}{c}{ about 20 cm depth core } \\
UKRB-1 & $0.74(0.36)$ & 8.17(3.39) & $0.06(0.02)$ & $0.60(0.20)$ \\
UKRB-3 & $0.16(0.11)$ & $1.79 .(1.17)$ & $0.04(0.02)$ & $0.53(0.12)$ \\
UKRB-4 & $0.15(.04)$ & $1.75 .(0.39)$ & $0.04(0.01)$ & $0.45(0.35)$ \\
\hline
\end{tabular}

\section{Discussion}

Percent nutrient concentration of soils in the three riparian WRP wetlands along the Sprague River illustrated a gradient, with highest concentrations in soils from the site farthest upstream (UKRB-1) and lowest concentrations in soils at the site farthest downstream (UKRB-4) (fig. 5). This may be an artifact of small sample size, but we suspect that it reflects actual conditions. The confluence of the Sycan River with the Sprague River is downstream of site UKRB-1 and the Sycan River introduces volcanic soils that likely differ from soils of the Upper Sprague River. Although the most upstream WRP, site UKRB-1, has been under easement only a few years, the site is undisturbed and likely received only grazing before being enrolled. The two downstream sites (UKRB-3 and -4) border a rural subdivision, contain extensive levees and were likely disturbed prior to restoration. Litter depth in UKRB wetlands sampled was deeper than in most CCV wetlands. Percentages of nitrogen and carbon in the UKRB wetlands we sampled also were higher than percentages in CCV wetlands. Percentage of soil phosphorus, however, did not appear to differ between UKRB and CCV wetlands. 


\section{Chapter K: Sediment and Nutrient Yields in the Upper Klamath River Basin (UKRB)}

By Rosemary M. Records, U.S. Geological Survey; Sharon N. Kahara, Humboldt State University; and Walter G. Duffy, U.S. Geological Survey

\section{Introduction}

Sediment loads vary across the United States, but generally are considered to be indicative of nutrient enrichment, particularly where they occur in excess (U.S. Environmental Protection Agency, 2001). Phosphorus particles adsorbed onto sediment particles may become bioavailable, leading to eutrophication (Carpenter and others, 1998). Sediments also bind to and transport pesticides, metals and other toxic compounds to surface waters (Holmes, 2004; McKee and others, 2006).

Upper Klamath Lake, located in southern Oregon, is a large relatively shallow lake. The lake was historically eutrophic due to the phosphorus rich volcanic soils. However, the development of nuisance blooms of Aphanizomenon flos-aquae in recent years has resulted in hypereutrophic status, threatening local fish species. Upper Klamath Lake and Agency Lake are both hypereutrophic due to elevated algae growth from high nutrient loading, including phosphorus (Boyd and others, 2002). Deteriorating water quality in Upper Klamath and Agency Lake is associated with large kills of federally listed endangered species; the Lost River sucker (Deltistes luxatus) and the shortnose sucker (Chasmistes brevirostris) (Carpenter and others, 2009). A wide variety of fish species are present in the Upper Klamath Lake drainage basin, including the interior redband trout (Oncorhynchus mykiss), bull trout (Salvelinus confluent), the Lost River sucker and the shortnose sucker. So, water quality is a key concern for the area (Boyd and others, 2002).

Rivers draining to Upper Klamath Lake have been listed on the 1998 Oregon Section 303(d) Clean Water Act for temperature, dissolved oxygen (DO), sediment, chlorophyll-a, pH, and habitat modification. Beginning in the 1890s, wetlands in the upper Klamath River basin were drained for cattle grazing, barley, hay, wheat, and other crops, including about 12,500 ha of wetlands adjacent to Agency and Upper Klamath Lakes. Wetland drainage may speed decomposition and accelerate nutrient releases to waterways. Restoration of drained wetlands is one management strategy used to improve water quality and decrease nutrient loading into Upper Klamath Lake (Carpenter and others, 2009).

\section{Study Area}

The Upper Klamath Lake drainage is composed of the Upper Klamath Lake, Wood River, Williamson River, and the Sprague River subbasins (fig. K1). Land ownership in the Upper Klamath Lake drainage is mostly private and U.S. Forest Service. Land use is predominantly forested and shrubland or grassland, with some farming, grazing, and wetlands. 


\section{Methods}

We used ArcSWAT 2009.93.4 (Winchell and others, 2010) to model discharge and sediment yields in the subbasins of the Upper Klamath Lake; including the Wood, Sprague, and Williamson Rivers. The Soil and Water Assessment Tool (SWAT) is a spatially explicit, continuous simulation model developed by the USDA Agricultural Research Service (USDAARS). The model is designed to quantify management and land use effects on water-quality parameters in agricultural areas. Parameters include water discharge, sediment yields, and nutrient loading. Hydrology is simulated using a mass balance with terms representing percolation, surface runoff, evapotranspiration, lateral surface flow, and other parameters. The user supplies spatial and tabular inputs of elevation, land use and land cover, and may further customize the model with management operations; point sources; reservoirs, ponds and wetlands; and weather, soil, and water-use parameters (Vache and Eilers, 2005; Winchell and others, 2010).

The SWAT is one of two models used in CEAP USDA Agricultural Research Service benchmark watershed studies (Richardson and others, 2008), and is well suited to modeling watershed-scale water-quality effects of conservation areas (Liu and others, 2008). A previous study on the Sprague River found that SWAT modeled monthly discharge reasonably well for a 5-year calibration period in the early to mid-1990s. SWAT suspended solid and nutrient load estimates for the Sprague River were in close agreement with USGS SPARROW models for the area, further suggesting SWAT has promise for UKRB water quality modeling.

Results presented are preliminary, and will be calibrated and validated with USGS and Klamath Tribes stream gage and water-quality data for discharge and sediment (turbidity or total suspended solids) data. Future modeling will examine the effects of conservation acreage, including WRP, on key water-quality parameters for the UKRB, and will be developed in cooperation with the Integrated Landscape Modeling, Mississippi Alluvial Valley Riverine group.

Values (metric tons per year) are estimated for the subbasin farthest downstream in the modeled basin (subbasin 23 in the Williamson and Sprague Rivers, and subbasin 18 in the Upper Klamath Lake basin) (fig. K1). 


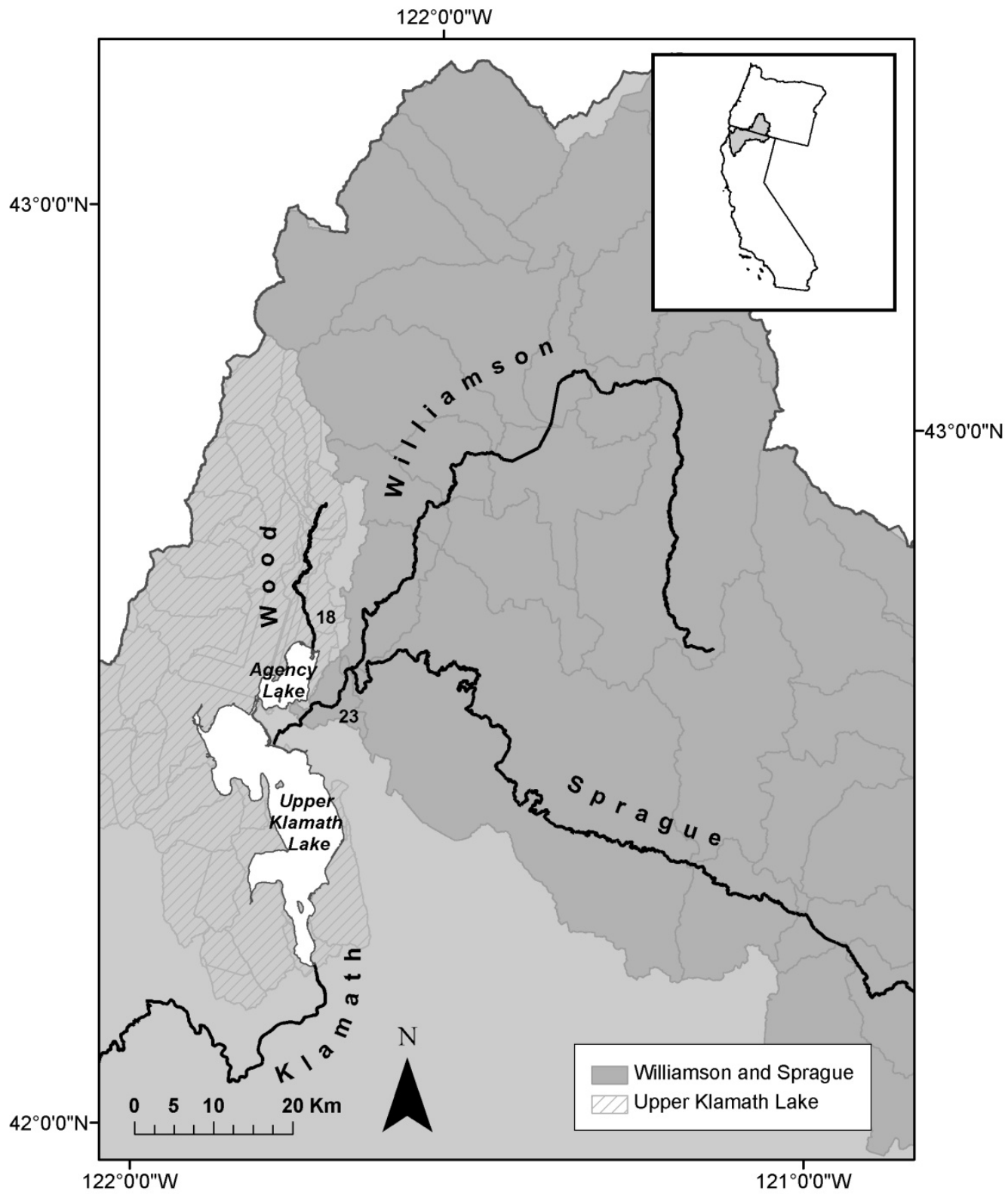

Figure K1. Basins and subbasins for ArcSWAT model in the Upper Klamath River basin. The most downstream subbasin for the Williamson and Sprague River basins and for the Wood River basin are marked. 


\section{Results}

Modeled total annual sediment yields from the Sprague and Williamson Rivers generally were higher than yields from the Wood River basin for the same year, with the highest annual yield in 1996 at about 38,000 metric tons for the year and relatively high interannual variation (fig. K2). In the Wood River basin, modeled sediment yields were highest in the 1970s at about 24,000-37,000 metric tons per year, and lowest in 1998 at about 900 metric tons per year (fig. $\mathrm{K} 2)$.

Average annual nitrogen yields in the Wood River basin generally were higher than that of the Williamson and Sprague Rivers with the exception of the years 1979, 1981, 1998 (fig. K3). Average phosphorus yields also were higher in the Wood River basin (fig. K4). Wood River hydrology is dominated by groundwater (base flow), and has relatively little seasonal variation in flows, unlike the more surface runoff-dominated Sprague River and, to a lesser extent, Williamson River (Gannett and others, 2010). Flow fractions (for example, relative proportions and temporal variation in surface runoff versus groundwater) play an important role in sediment and nutrient entrainment, transport, cycling, and deposition. Results are reported for preliminary, uncalibrated model results prior to adjustment of model parameters to reflect true basin hydrology. Comparisons of observed and simulated flows for the Wood show that SWAT is over-predicting surface runoff in preliminary simulations, and hydrologic parameters will require further adjustment to accurately model hydrologic, sediment and nutrient loads under various levels of wetland restoration. As model calibration and validation is ongoing, effects of WRP are as yet unknown.

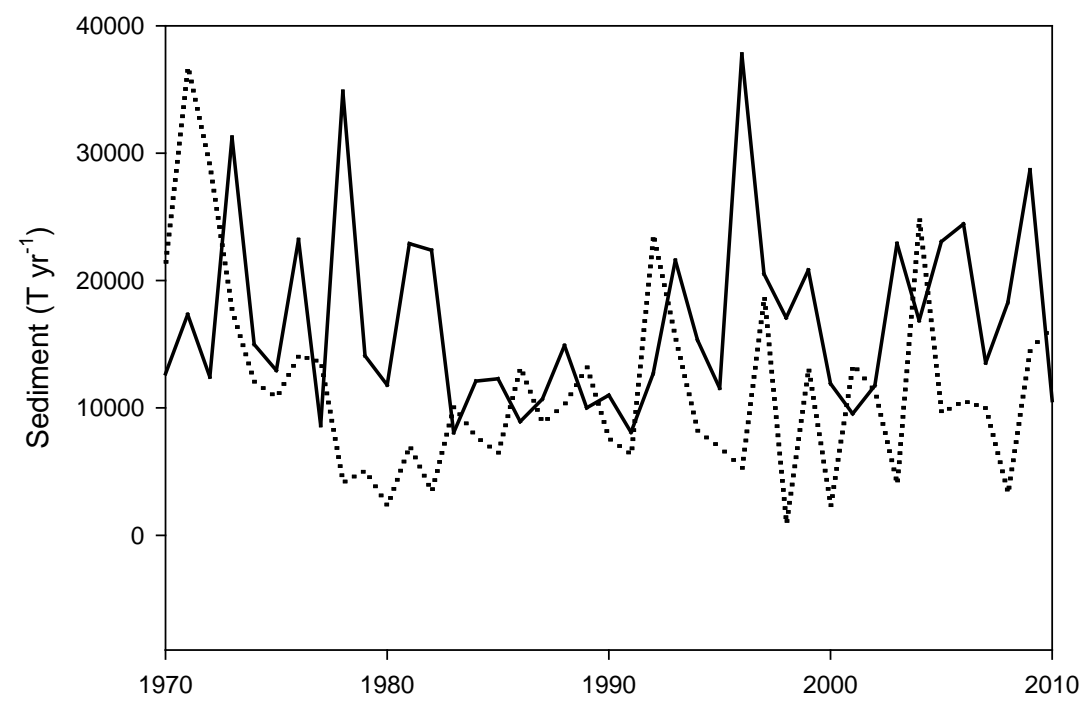

Figure K2. ArcSWAT modeled total annual sediment yields of Williamson River and Sprague River watersheds (combined; solid line) and Wood River watershed (dotted line), 1970-2010. Values (metric tons/year) are estimated for the subbasin farthest downstream in the modeled basin. 


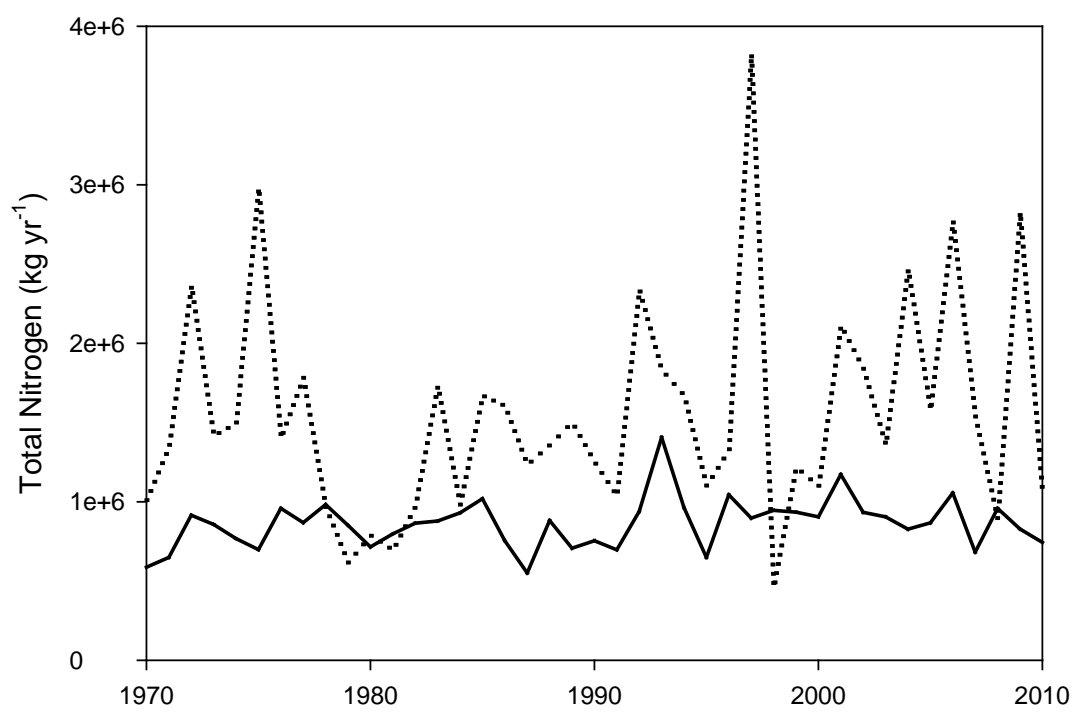

Figure K3. ArcSWAT modeled total nitrogen of Williamson River and Sprague River watersheds (combined; solid line) and Wood River watershed (dotted line), 1970-2010. Values (metric tons/year) are estimated for the subbasin farthest downstream in the modeled basin.

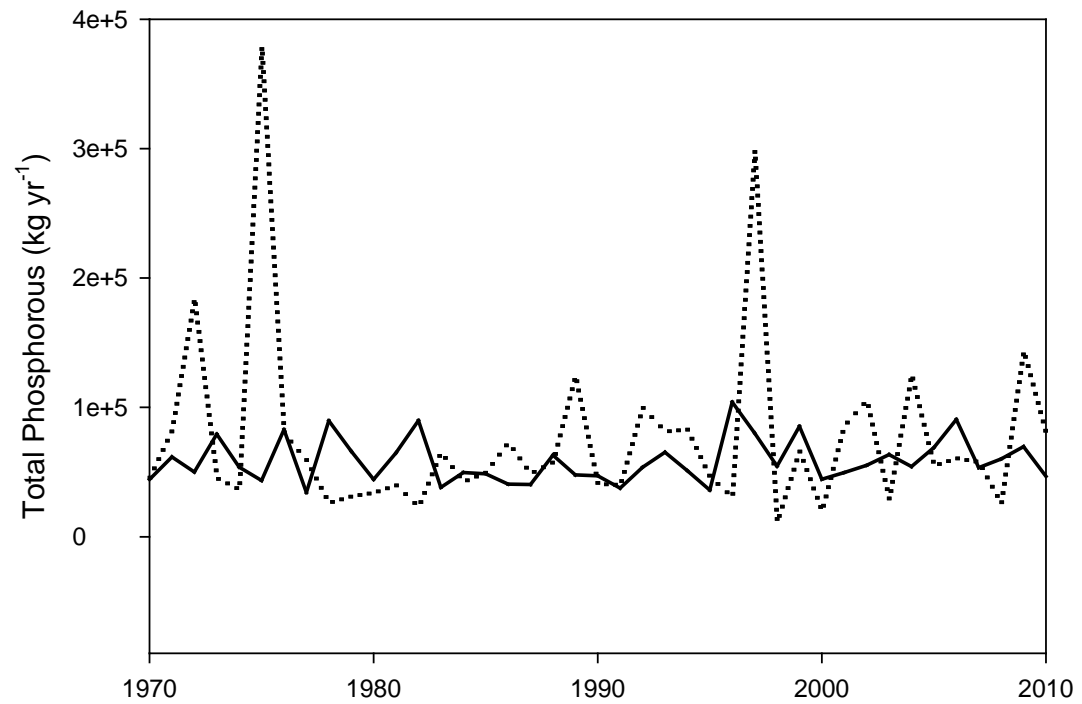

Figure K4. ArcSWAT modeled total phosphorus of Williamson River and Sprague River watersheds (combined; solid line) and Wood watershed (dotted line), 1970-2010. Values (metric tons per year) are estimated for the subbasin farthest downstream in the modeled basin. 


\section{Current Status of Data Analysis}

There is often a close relationship between sediment loads and nutrient loads (U.S. Environmental Protection Agency, 2001), and we have presented preliminary SWAT sediment yield estimates here pending incorporation of conservation practices and calibration and validation of the model. 


\title{
Chapter L: Amphibian Use of Wetlands Reserve Program (WRP) in the Upper Klamath River Basin
}

\author{
By Walter G. Duffy, U.S. Geological Survey; and Luke Groff, Humboldt State University
}

\section{Objective}

We surveyed amphibian use of WRPs in the UKRB as part of our assessment of biodiversity, as well as to evaluate the distribution and relative abundance of anuran species in the UKRB.

\section{Methods}

Amphibian surveys were conducted on nine WRP easements in the UKRB between June and July 2008. Survey techniques included dipnet, visual encounter, and aural recording methodologies. Dipnet and visual encounter surveys were conducted during daylight between 0900 and $1600 \mathrm{~h}$. This technique required two surveyors to slowly walk around the wetland perimeter at the waterline, stopping often to scan ahead for amphibians. One surveyor focused on the land-water interface while the other focused on the shallow water zone $(\leq 1 \mathrm{~m})$. Overhangs, ledges, and vegetation were investigated for the presence of amphibians. Surveyors wore polarized sunglasses to reduce the reflective glare on the water's surface and carried dipnets to capture individuals for identification or museum voucher purposes. Collected amphibians were identified using a variety of guides, including Stebbins (2003) and Altig and others (2007).

At several larger easements, 25 percent of the wetland perimeter was subsampled. These subsamples were apportioned relative to habitat type (for example, forested and non-forested, vegetated and non-vegetated, etc.) and were distributed around the wetland perimeter.

Aural recordings were used to detect nocturnal breeding activities (that is, vocalizations) of adult, male anurans that may not have been observed during visual surveys. At each WRP easement, a single Wildlife Acoustic SM1 Song Meter recorder was installed along the northern perimeter of the wetland. Recorders were programmed to record the first 20 min of each hour between 2000 and $0500 \mathrm{~h}$ (that is, 2000-2020 h, 2100-2120 h, etc.).

Recordings were reviewed at Humboldt State University. The first 5 min (for example, 2000-2005 h, 2100-2105 h, etc.) of each hourly recording was reviewed at a standardized volume and all amphibian vocalizations were identified and tallied. If the first 5- min interval was inaudible (for example, wind, static, bird clamor), the second 5-min interval (for example, 2005-2010 h, 2105-2110 h, etc.) was reviewed, and so on.

To reduce the potential spread of infectious diseases, all organic matter was removed from nets, boots, and other gear before leaving each WRP. These items were scrubbed, soaked in a Quat-128 ${ }^{\mathrm{TM}}$ solution (1:60), and rinsed with clean water prior to surveying another site. Data on anuran distribution and abundance was limited to two visits. These visits yielded categorical estimates of abundance and fragmentary distribution observations, neither of which supported statistical analyses. 


\section{Results}

Four species of amphibians were detected on the nine WRP wetlands surveyed (table L1). Abundance was recorded categorically (that is, 101-1,000; 1,001-10,000; etc.). Abundance of most species and life stages was low, 10 or fewer. Exceptions included Pacific chorus frog (Pseudacris regilla) larvae, with an abundance of 101-1,000 at site UKRB-4 and 1,001-10,000 at site UKRB-8; western toad (Anaxyrus boreas) larvae, with an abundance of 101-1,000 at site UKRB-4; and American bullfrog (Lithobates catesbeianus) larvae and juvenile/adults, each with an abundance of 11-100 at site UKRB-11.

Amphibian species richness (R) was low, ranging from 1.0 at three sites to 4.0 at one site. Average R among the nine sites was 2.0 (standard deviation 1.0). The American bullfrog was the most common species encountered and was detected on eight of nine WRP wetlands. Pacific chorus frogs were detected at five sites, while western toads and long-toed salamanders (Ambystoma macrodactylum) were each detected at two sites.

Table L1. Species of amphibians detected at sites sampled in the Upper Klamath River Basin in June and July 2008.

[Life stages detected were egg (E), larvae (L), and juveniles or adults (J/A)]

\begin{tabular}{lcccc}
\hline Site & $\begin{array}{c}\text { Long-toed } \\
\text { Salamander }\end{array}$ & $\begin{array}{c}\text { Western } \\
\text { toad }\end{array}$ & Pacific chorus frog & $\begin{array}{c}\text { American } \\
\text { Bullfrog }\end{array}$ \\
\hline UKRB-2 & & & & $\mathrm{J} / \mathrm{A}$ \\
UKRB-4 & $\mathrm{L}$ & $\mathrm{L}$ & $\mathrm{L}-\mathrm{J} / \mathrm{A}$ & $\mathrm{E}-\mathrm{L}-\mathrm{J} / \mathrm{A}$ \\
UKRB-5 & & & & $\mathrm{J} / \mathrm{A}$ \\
UKRB-6 & & $\mathrm{L}-\mathrm{J} / \mathrm{A}$ & $\mathrm{J} / \mathrm{A}$ & $\mathrm{L}-\mathrm{J} / \mathrm{A}$ \\
UKRB-7 & $\mathrm{L}$ & $\mathrm{L}-\mathrm{J} / \mathrm{A}$ & \\
UKRB-8 & & $\mathrm{J} / \mathrm{A}$ & $\mathrm{L}-\mathrm{J} / \mathrm{A}$ \\
UKRB-9 & & $\mathrm{J} / \mathrm{A}$ & $\mathrm{J} / \mathrm{A}$ \\
UKRB-10 & & & $\mathrm{J} / \mathrm{A}$ \\
UKRB-11 & & & $\mathrm{L}-\mathrm{J} / \mathrm{A}$ \\
\hline
\end{tabular}

\section{Discussion}

We found four species of amphibians at the nine wetlands surveyed in 2008. The most common species encountered was the American bullfrog, an invasive species native to eastern U.S. Pacific chorus frogs, a native species, were found at five of the nine sites, while two other species were each found at two sites. The abundance of each species generally was less than 10, with few exceptions. Those exceptions included American bullfrog and pacific chorus frog eggs and larvae, which were abundant at several sites. Overall, amphibian diversity on surveyed UKRB wetlands was low, with species richness averaging 2.0 and ranging from 1 to 4, but includes all species expected in this region. We recommend future studies focus on abundance relative to habitat availability and presence of potential threats. 


\title{
Chapter M: Bird use of Wetlands Reserve Program (WRP) in the Upper Klamath River Basin (UKRB)
}

\author{
By Walter G. Duffy, U.S. Geological Survey
}

\section{Objective}

We surveyed bird use of WRPs in the UKRB as part of our assessment of biodiversity.

\section{Methods}

Five-minute variable circular point count surveys were conducted at three WRP easements along the Sprague River in the UKRB in March (site UKRB-3) and July 2009 (sites UKRB-1 and -4) following nationally standardized protocol (Ralph and others, 1995).

For the 5-min variable circular plot point count method, the distance from the observer to each individual bird (including aerially foraging raptors and swallows, see table M1 for scientific names) is estimated (Ralph and others, 1995). We estimated detections in bands of $10 \mathrm{~m}$ outward to $50 \mathrm{~m}$. Three bands extend farther (50-75 m, 75-100 m, and > $100 \mathrm{~m}$ ). Type of detection (that is song, visual, or call) and breeding behavior (for example, copulation, nest building, food carry to fledgling) were recorded. Birds flying over the point count station were recorded separately and excluded from analyses. All transects were observed a single time in March (sites UKRB-4A and -4B) or July 2009 (sites UKRB-1 and -3). Surveys were completed within 4 h of local sunrise by experienced observers trained in visual and auditory bird identification and distance estimation. Because detection rates of most species generally decrease beyond a 50-m distance from the observer, we have only included detections from within $50 \mathrm{~m}$ of each point count station for data analysis. The limited sample size required all data to be assessed qualitatively.

\section{Results}

Twenty taxa of birds were observed at riparian wetlands within the three WRP easements along the Sprague River (table M1). Species richness was seven to eight at the sites surveyed in July 2009 (sites UKRB-1 and -4) and four at site UKRB-3, surveyed in March 2009. Four species were observed at two or more sites: Mallard, Red-winged Blackbird, Song Sparrow, and unidentified swallows (see table M1 for scientific names). All other species were observed at only one site. None of the species observed was abundant.

Birds observed at the three sites represented eight foraging guilds (table M2), groupings of birds that share ecological requirements and behaviors (Hickey and others, 2008). Six species were from the upland bird guild and three species were from the marsh bird guild. Species from each of these guilds were observed at all three sites. The other six guilds were represented by one or two species. 
Table M1. Numbers of each species observed at sites UKRB-1, -3, and - 4 in the Upper Klamath River Basin in 2009.

[All transects were observed a single time in March (sites UKRB-4A and -4B) or July of 2009 (sites UKRB-1 and 3)]

\begin{tabular}{lllllll}
\hline \multirow{2}{*}{\multicolumn{1}{c}{ Common name }} & \multicolumn{1}{c}{ Genus } & \multicolumn{1}{c}{ Species } & $\mathbf{1}$ & $\mathbf{3}$ & 4A & 4B \\
\cline { 3 - 6 } American goldfinch & Carduelis & tristis & 1 & 0 & 0 & 0 \\
American white pelican & Pelecanus & erythrorhynchos & 0 & 0 & 0 & 15 \\
Barn swallow & Hirundo & rustica & 1 & 0 & 0 & 0 \\
Brewer's blackbird & Euphagus & cyanocephalus & 0 & 0 & 0 & 1 \\
Canada goose & Branta & canadensis & 0 & 4 & 0 & 0 \\
Great blue heron & Ardea & herodias & 0 & 0 & 1 & 0 \\
Killdeer & Charadrius & vociferus & 0 & 2 & 0 & 0 \\
Mallard & Anas & platyrhynchos & 0 & 3 & 0 & 1 \\
Marsh wren & Cistothorus & palustris & 0 & 0 & 0 & 2 \\
Northern flicker & Colaptes & auratus & 5 & 0 & 0 & 0 \\
Red-winged blackbird & Agelaius & phoeniceus & 1 & 0 & 11 & 20 \\
Sandhill crane & Grus & canadensis & 0 & 3 & 0 & 0 \\
Song sparrow & Melospiza & melodia & 1 & 0 & 4 & 3 \\
Unidentified sparrow & Emberizidae & & 1 & 0 & 0 & 0 \\
Unidentified swallow & Hirundinidae & & 4 & 0 & 22 & 0 \\
Virginia rail & Rallus & limicola & 0 & 0 & 0 & 1 \\
Unknown waterbird & (duck or grebe) & & 0 & 0 & 7 & 0 \\
Western meadowlark & Sturnella & neglecta & 0 & 0 & 1 & 0 \\
Unknown goldfinch & Carduelis & & 0 & 0 & 0 & 4 \\
Unidentified sandpiper & Scolopacidae & & 0 & 0 & 2 & 0 \\
\hline
\end{tabular}


Table M2. Foraging guilds of birds, the number of birds belonging to each guild, the number of species belonging to each guild, and the number of sites at which the members of the guild were observed at UKRB-1, -3 , and -4 wetlands in the Upper Klamath River Basin.

[All transects were observed a single time in March (sites UKRB-4A and -4B) or July 2009 (sites UKRB-1 and -3). Guilds based on PRBO Conservation Science foraging guilds, groupings of birds that share ecological requirements and behaviors (Hickey and others, 2008)]

\begin{tabular}{|c|c|c|c|}
\hline Guild & Number & Number species & Number sites \\
\hline Aerial feeders & 27 & 2 & 2 \\
\hline Dabbling ducks & 4 & 1 & 2 \\
\hline Geese & 4 & 1 & 1 \\
\hline Large wading birds & 4 & 2 & 2 \\
\hline Marsh birds & 33 & 3 & 3 \\
\hline Shorebirds & 2 & 1 & 1 \\
\hline Surface divers & 15 & 1 & 1 \\
\hline Upland birds & 21 & 6 & 3 \\
\hline
\end{tabular}

\section{Discussion}

We observed 20 species of birds, representing eight foraging guilds, using riparian WRP wetlands along the Sprague River.

One species, the sandhill crane, is classified as threatened. Numbers of birds observed were not large, likely because the time of surveys (March and July) did not coincide with migration. The eight guilds observed suggests riparian WRP wetlands we sampled are providing a variety of habitats for birds, ranging from divers to shorebirds to upland species. 
This page left intentionally blank 


\section{Chapter N: Fish Use of Wetlands Reserve Program (WRP) in the Upper Klamath River Basin (UKRB)}

By Walter G. Duffy, U.S. Geological Survey; and Stephen Zipper, Humboldt State University

\section{Objective}

We sampled fish in riparian WRP wetlands along the Sprague River to evaluate their use of these habitats and, more specifically, use of these wetlands by endangered sucker species.

\section{Methods}

Riparian wetlands on three WRP easements adjacent the Sprague River in the UKRB (fig. 5, sites UKRB-1, -3, and -4), were sampled during April-June 2009 and 2010. Sampling was designed to determine wetland use by the larval stage of three sucker species: Lost River sucker (Deltistes luxatus), shortnose sucker (Chasmistes brevirostris), and Klamath large-scale sucker (Catostomus snyderi). Other fish species encountered also were enumerated. The Lost River sucker and shortnose sucker were listed under the Endangered Species Act (ESA) in 1988 (Tomelleri, 2007a, 2007b).

In 2009, we used belt transect surveys and dip netting to visually estimate presence and abundance of larval suckers. Habitats sampled included the mainstem Sprague River, backwaters directly connected to the mainstem such as alcoves, and wetland areas behind flood gate structures and levees. Species diversity was noted when non-sucker species were encountered.

In 2010, we used trap netting and dip netting to estimate the abundance of larval suckers and other fish species. Habitats sampled in 2010 included the inflow from the river to the WRP, the outflow from the WRP to the river and the mainstem Sprague River adjacent the WRP. Duplicate traps were set in these habitats at 1600-1700 $\mathrm{h}$ and retrieved the following morning at 0900-1100 h. Duplicate dip net samples were collected in these same habitats during 1200-1600

$\mathrm{h}$, after traps had been retrieved. Dip net samples were standardized to 3-min sweeps, with 10-20 samples collected from each WRP each week. Fish collected were identified in the field, whenever possible, and their standard length was recorded. Species of sucker larvae cannot be distinguished in the field and are reported here collectively as sucker larvae.

Data on fish distribution and abundance were gathered during three sampling visits in 2009, then weekly in 2010. Sampling was carried out April through June of both years when riparian wetlands normally flood. However, both 2009 and were dry years and riparian wetland flooding was inconsistent from site to site. Because data on the distribution and abundance of fish species were limited in 2009 and because field sampling in 2010 was terminated shortly before this report was completed, the analysis presented here is qualitative. Emphasis was placed on looking for consistency, or lack thereof, in distribution and abundance. 


\section{Results}

In 2009, a total of 620 fish were collected during sampling, 414 with dip nets, and 216 using electrofishing gear. Visual surveys yielded 343 suckers and 45 non-suckers. The most common species collected were larval suckers (tables N1 and N2). Sucker larvae made up 85 percent of the fish collected using dipnetting and 14 percent of the fish collected with electrofishing gear. Blue chub were the most common species collected with electrofishing gear, making up 41 percent of the fish collected with that gear. Other species represented from 0 to 5 percent of the total fish collected using dipnetting and from 0.4 to 13 percent of the total collected using electrofishing.

In 2010, a total of 1,841 fish were collected-1,482 with dip nets and 359 with traps. The most common species collected with dip nets were sculpin (Cottus spp.). At least nine species were collected with dip nets (fig. N1). The most common species collected with traps was blue chub (Gila coreulea). A total of 11 species were recorded in traps (fig. N2).

Dip net samples were large enough to explore temporal and spatial trends in catches. The majority of sucker larvae were captured during week 19, May 10-12, with relatively low numbers captured during other weeks (table N3). Furthermore, almost all sucker larvae captured on week 19 were captured from WRP site 4, the farthest downstream site. With the exception of unidentified chubs, which were more common in June than either April or May, other common species did not exhibit strong temporal trends in abundance.

Spatial patterns in total fish abundance varied somewhat among the three WRP sites. Catches at WRP site 1 were greater in the river than in the wetland on most dates and catches in the wetland inflow generally were low (fig. N3). Catches at WRP site 3 did not exhibit strong patterns, although catches in the outflow were low in April, then increased above those in the inflow and the river in June. Catches in the wetland at WRP site 4 were often greater than in the river and catches in the wetland outflow were often greater than in the wetland inflow. Interestingly, high catches in the wetland outflow during week 19 were almost entirely sucker larvae (fig. N3). 
Table N1. Number of six species of fish collected using dipnets from three riparian wetlands within WRP easements along the Sprague River, Oregon.

[Week = week of the year]

\begin{tabular}{|c|c|c|c|c|c|c|}
\hline Week & Sucker larvae & Blue chub & $\begin{array}{c}\text { Brown } \\
\text { bullhead }{ }^{1}\end{array}$ & $\begin{array}{c}\text { Unidentified } \\
\text { chub }^{2}\end{array}$ & Sculpin & $\begin{array}{c}\text { Speckled } \\
\text { dace }^{3}\end{array}$ \\
\hline & \multicolumn{6}{|c|}{ Site UKRB 1} \\
\hline 16 & 0 & 0 & 0 & 0 & 0 & 0 \\
\hline 17 & 0 & 36 & 0 & 0 & 0 & 0 \\
\hline 19 & 0 & 0 & 0 & 0 & 0 & 0 \\
\hline \multirow[t]{2}{*}{22} & 0 & 0 & 0 & 0 & 0 & 0 \\
\hline & \multicolumn{6}{|c|}{ Site URKB 3} \\
\hline 16 & 0 & 0 & 0 & 0 & 0 & 0 \\
\hline 17 & 23 & 0 & 0 & 0 & 0 & 0 \\
\hline 19 & 33 & 0 & 0 & 3 & 9 & 0 \\
\hline \multirow[t]{2}{*}{22} & 0 & 0 & 0 & 0 & 0 & 0 \\
\hline & \multicolumn{6}{|c|}{ Site UKRB 4} \\
\hline 16 & 159 & 0 & 0 & 0 & 0 & 0 \\
\hline 17 & 106 & 0 & 0 & 0 & 0 & 0 \\
\hline 19 & 28 & 0 & 2 & 6 & 8 & 0 \\
\hline 22 & 1 & 0 & 0 & 0 & 0 & 0 \\
\hline
\end{tabular}

${ }^{1}$ Scientific names are: brown bullhead ( Ameiurus nebulosus), unidentified chubs were either Gila coreulea or G. bicolor, and speckled dace (Rhinichthys osculus). 
Table N2. Species and numbers of fish collected with electrofishing gear from three riparian wetlands within WRP easements along the Sprague River, Oregon ${ }^{1}$.

[Week $=$ week of the year]

\begin{tabular}{|c|c|c|c|c|c|c|c|c|c|c|}
\hline Week & $\begin{array}{l}\text { Sucker } \\
\text { larvae }\end{array}$ & $\begin{array}{l}\text { Blue } \\
\text { chub }\end{array}$ & $\begin{array}{c}\text { Brown } \\
\text { bullhead }\end{array}$ & $\begin{array}{c}\text { Black } \\
\text { bullhead }{ }^{1}\end{array}$ & Sculpin & $\begin{array}{c}\text { Speckled } \\
\text { dace }\end{array}$ & $\begin{array}{l}\text { Fathead } \\
\text { minnow }^{1}\end{array}$ & $\begin{array}{l}\text { Yellow } \\
\text { perch }^{1}\end{array}$ & $\begin{array}{c}\begin{array}{c}\text { Tui } \\
\text { chub }^{1}\end{array} \\
\end{array}$ & $\begin{array}{l}\text { Rainbow } \\
\text { trout }^{1}\end{array}$ \\
\hline & \multicolumn{10}{|c|}{ Site UKRB 1} \\
\hline 17 & 0 & 3 & 0 & 0 & 4 & 0 & 1 & 0 & 2 & 1 \\
\hline 19 & 0 & 0 & 0 & 0 & 0 & 0 & 0 & 0 & 0 & 0 \\
\hline \multirow[t]{2}{*}{22} & 0 & 9 & 0 & 0 & 3 & 1 & 2 & 0 & 4 & 2 \\
\hline & \multicolumn{10}{|c|}{ Site UKRB 3} \\
\hline 17 & 0 & 51 & 0 & 1 & 1 & 2 & 0 & 0 & 0 & 0 \\
\hline 19 & 0 & 0 & 0 & 0 & 0 & 0 & 0 & 0 & 0 & 0 \\
\hline \multirow[t]{2}{*}{22} & 17 & 15 & 0 & 0 & 0 & 4 & 8 & 0 & 2 & 0 \\
\hline & \multicolumn{10}{|c|}{ Site UKRB 4} \\
\hline 17 & 10 & 8 & 0 & 0 & 2 & 18 & 0 & 3 & 0 & 0 \\
\hline 19 & 3 & 0 & 12 & 0 & 2 & 1 & 0 & 5 & 0 & 1 \\
\hline 22 & 1 & 3 & 5 & 4 & 0 & 1 & 1 & 2 & 0 & 0 \\
\hline
\end{tabular}

${ }^{1}$ Scientific names are: black bullhead ( Ameiurus melas), fathead minnow (Pimephales promelas), Tui chub (Gila bicolor), yellow perch (Perca flavescens), rainbow trout (Oncorhynchus mykiss), one spotted bass (Micropterus punctulatus )was also collected from site 4 during week 19.

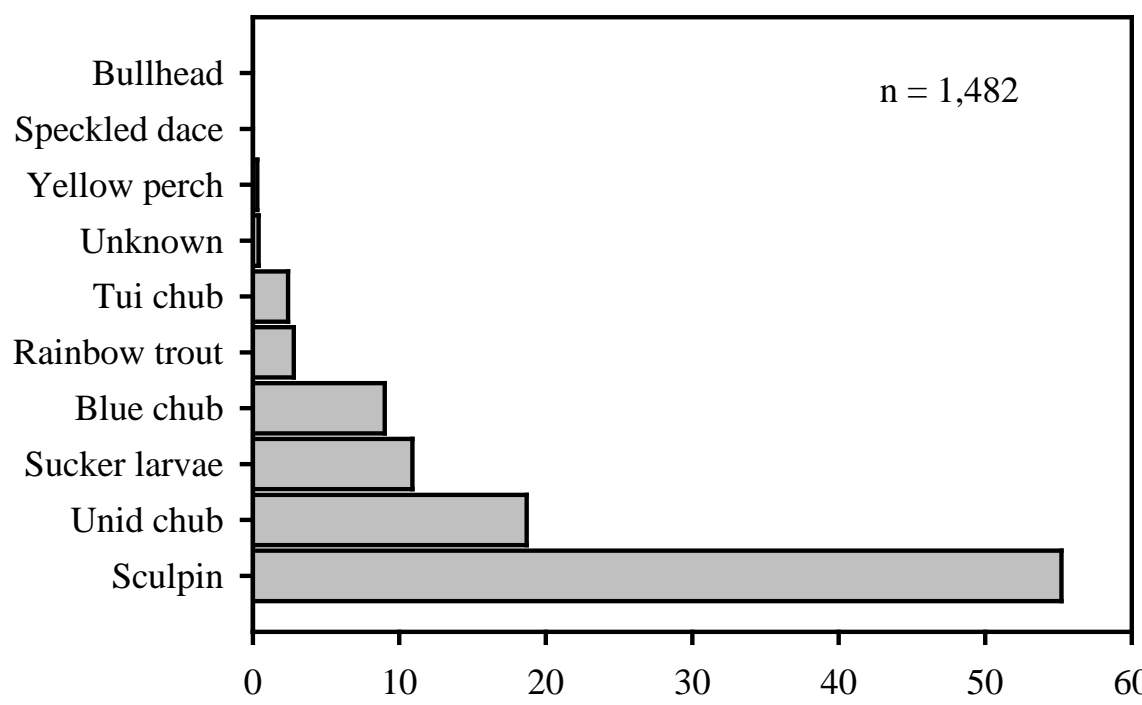

Percent of Catch

Figure N1. Frequency distribution of fish species captured using dip net sampling in three riparian WRP wetlands along the Sprague River, Oregon, 2010. 


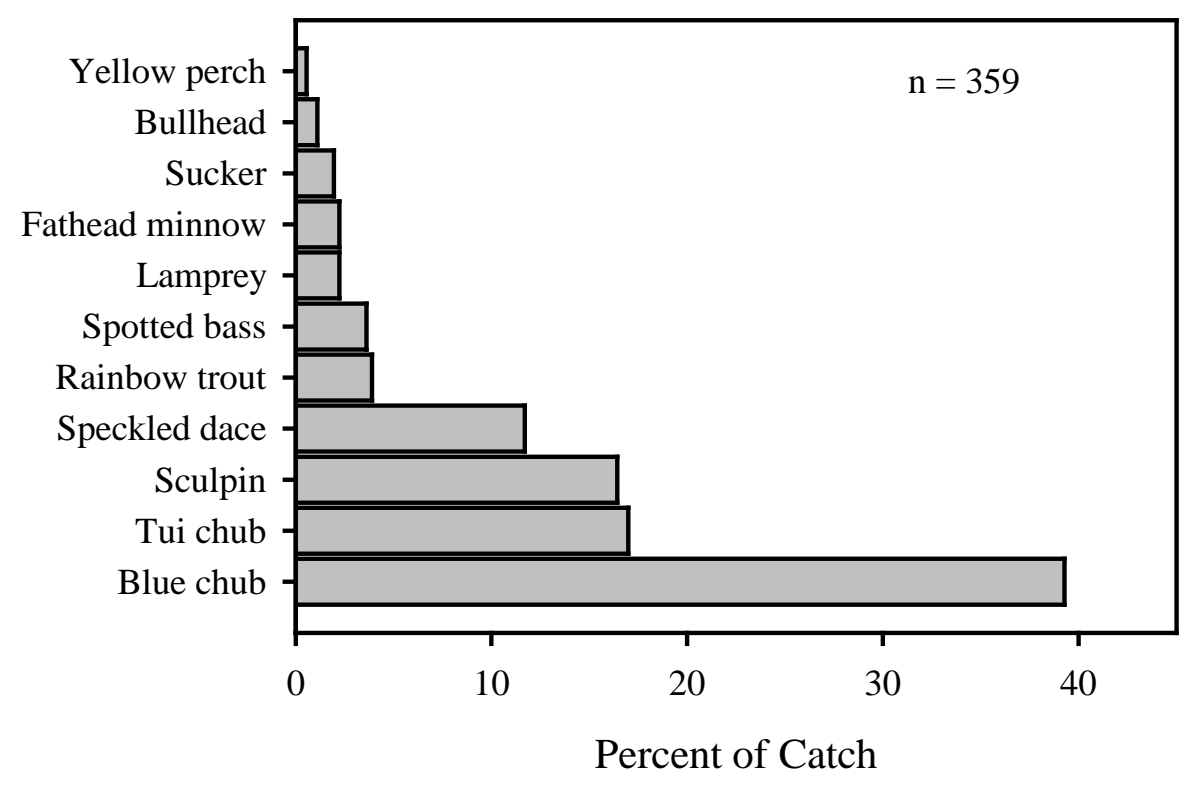

Figure N2. Frequency distribution of fish species captured using trap net sampling in three riparian WRP wetlands along the Sprague River, Oregon, 2010.

Table N3. Number of fish species captured during dip net sampling at WRP wetland sites UKRB 1, 3, and 4 along the Sprague River, Oregon, 2010.

\begin{tabular}{lccccccc}
\hline Week & \multicolumn{7}{c}{ Species } \\
\cline { 2 - 8 } & $\begin{array}{c}\text { Blue } \\
\text { chub }\end{array}$ & $\begin{array}{c}\text { Unidentified } \\
\text { chub }\end{array}$ & Sucker larvae & Rainbow trout & Sculpin & $\begin{array}{c}\text { Tui } \\
\text { chub }\end{array}$ & Other \\
\hline 14 & 36 & 0 & 1 & 4 & 23 & 6 & 0 \\
15 & 13 & 0 & 4 & 3 & 80 & 3 & 1 \\
16 & 7 & 0 & 4 & 7 & 96 & 4 & 3 \\
17 & 7 & 0 & 8 & 12 & 74 & 1 & 0 \\
18 & 3 & 0 & 6 & 5 & 67 & 13 & 0 \\
19 & 15 & 2 & 107 & 5 & 82 & 3 & 4 \\
20 & 4 & 9 & 1 & 1 & 49 & 2 & 0 \\
21 & 2 & 17 & 9 & 2 & 97 & 0 & 0 \\
22 & 8 & 9 & 8 & 1 & 88 & 0 & 5 \\
23 & 0 & 3 & 4 & 0 & 26 & 1 & 0 \\
24 & 29 & 85 & 4 & 0 & 28 & 2 & 1 \\
25 & 9 & 152 & 1 & 2 & 108 & 1 & 0 \\
Total & $\mathbf{1 3 3}$ & $\mathbf{2 7 7}$ & $\mathbf{1 6 2}$ & $\mathbf{4 2}$ & $\mathbf{8 1 8}$ & $\mathbf{3 6}$ & $\mathbf{1 4}$ \\
\hline
\end{tabular}




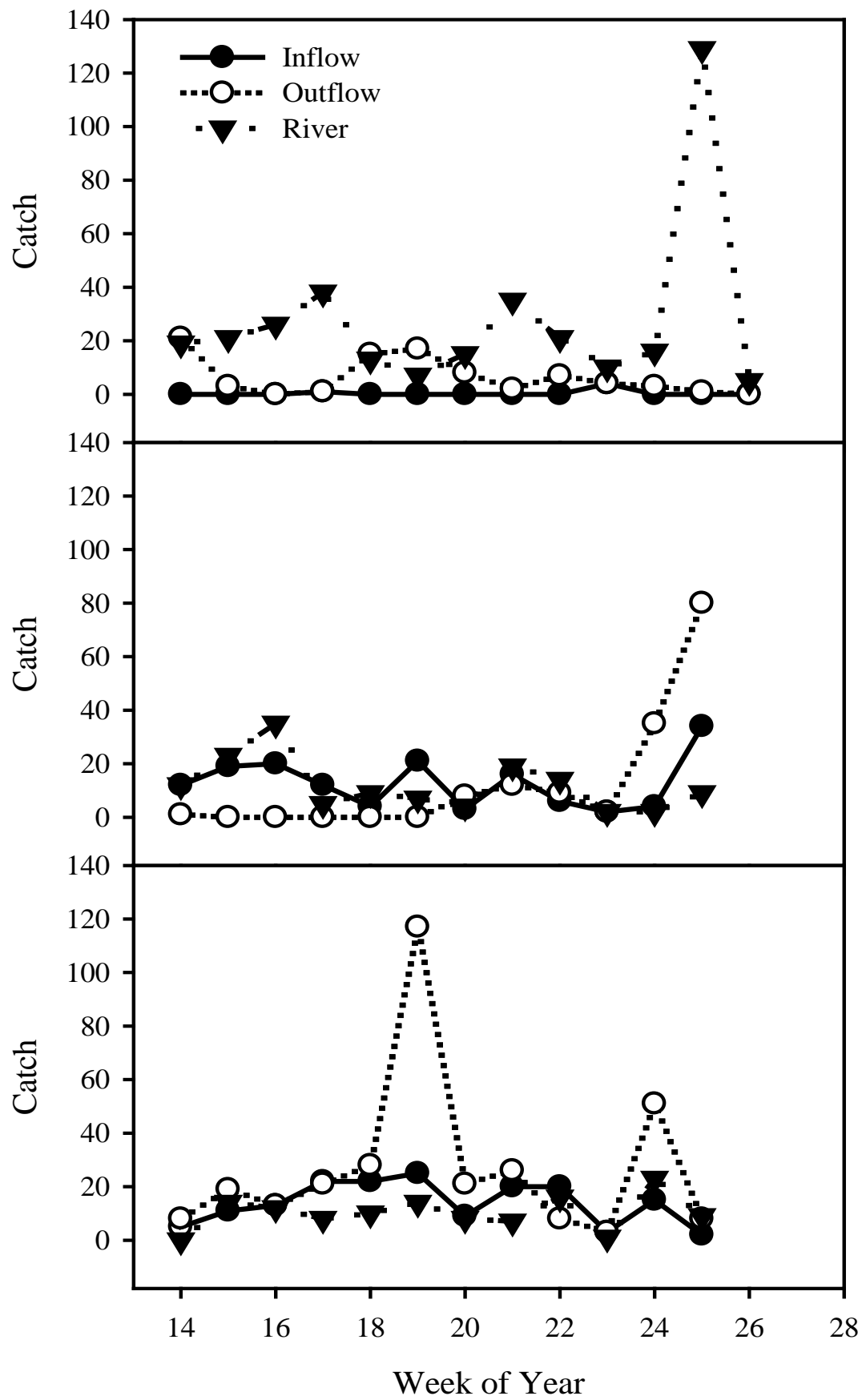

Figure N3. Number of fish captured weekly at the site UKRB 2 (top), site UKRB 3 (middle), and site UKRB 4 (bottom) WRPs. Data are from the WRP inflow (solid circle), outflow (open circle), and in the Sprague River adjacent the WRP (triangle). 
Size of common fish species captured varied somewhat within the three primary habitats sampled. Sucker larvae in the WRP wetland outflows were larger than in either the wetland inflow or the river (table N4). Sculpin and tui chub from wetland outflow habitats also were larger than in wetland inflow or river habitats. Conversely, blue chub in wetland outflow habitats were smaller than in other habitats (table N4).

Table N4. Average standard length $(\mathrm{mm})$ and standard deviation of standard length for fish species collected from the inflow, outflow, and in the river adjacent three WRPs during 2010.

[The number of length measurements recorded is denoted by “n”]

\begin{tabular}{|c|c|c|c|c|c|c|c|c|c|c|c|}
\hline \multirow[b]{2}{*}{ Species } & \multicolumn{3}{|c|}{ Inflow } & \multicolumn{3}{|c|}{ Outflow } & \multicolumn{3}{|c|}{ River } & \multirow{2}{*}{$\begin{array}{l}\text { Outflow - } \\
\text { Inflow }\end{array}$} & \multirow{2}{*}{$\begin{array}{l}\text { Outflow - } \\
\text { River }\end{array}$} \\
\hline & $n$ & Avg & SD & $n$ & Avg & SD & $n$ & Avg & SD & & \\
\hline Blue chub & 20 & 25.9 & 10.9 & 55 & 22.7 & 10.7 & 26 & 23.1 & 6.9 & -3.1 & -0.3 \\
\hline Unk chub & 26 & 15.0 & 2.6 & 40 & 14.5 & 3.1 & 4 & 13.5 & 2.6 & -0.5 & 1.0 \\
\hline $\begin{array}{l}\text { Sucker } \\
\text { larvae }\end{array}$ & 24 & 12.9 & 1.6 & 43 & 13.4 & 1.6 & 27 & 12.4 & 3.6 & 0.5 & 1.0 \\
\hline $\begin{array}{l}\text { Rainbow } \\
\text { trout }\end{array}$ & 1 & 31.0 & & 5 & 27.6 & 2.5 & 34 & 25.0 & 3.5 & -3.4 & 2.6 \\
\hline Sculpin & 197 & 18.1 & 5.7 & 153 & 20.3 & 5.8 & 353 & 18.4 & 5.5 & 2.2 & 1.9 \\
\hline Tui chub & 6 & 22.5 & 4.1 & 22 & 29.7 & 9.6 & 7 & 27.9 & 15.2 & 7.2 & 1.8 \\
\hline
\end{tabular}

\section{Discussion}

Eleven species of fish were found using WRP wetland habitats along the Sprague River in 2009 and 2010. In addition, one juvenile lamprey was collected from the Sprague River in 2010. The most abundant fish species collected in 2009 were larvae of suckers. In 2010, sucker larvae were common but less abundant than sculpin or chubs. Differences among years were due in part to collection methods used, but also reflect natural variation in abundance.

Larval suckers cannot be reliably distinguished in the field. However, information on the spatial distribution of adult suckers when spawning suggest the sucker larvae we collected were predominantly shortnose sucker, an Endangered Species Act (ESA) endangered species, with an unknown proportion being Klamath large-scale sucker. In 2009, more sucker larvae were collected at sites UKRB 3 and UKRB 4 than at site UKRB 1, despite the nearness of site UKRB 1 to known sucker spawning habitat in the Beatty Gap area of the Sprague River. Similarly, most sucker larvae were collected from site 4 in 2010.

Abundance of fish species in dip net samples did not show a strong temporal pattern, with the notable exception of sucker larvae. Almost two-thirds of the sucker larvae collected were collected on week 19 or May 10-12. Furthermore, most of the sucker larvae collected on week 19 were collected in the outflow from WRP site 4, suggesting they were leaving the wetland to migrate downstream to Upper Klamath Lake.

Spatially, fish use of WRP wetland habitats varied among sites. Abundance in wetland habitats of WRP site 1, the most upstream site, was most often less than abundance in the river. Lower abundance in wetland habitats than in the river adjacent this WRP is almost certainly related to the limited flooding during both years and to limited connectivity between the river 
and riparian wetland. In contrast, fish abundance in wetland habitats of WRP sites 3 and 4 often exceeded abundance in the river adjacent these sites. Both WRP sites 3 and 4 are connected to the river at moderate flows. Within wetland habitats, fish abundance in WRP outflow habitats exceeded, at times, abundance in inflow habitats. The greater abundance in the outflow relative the inflow may reflect differential efficiency in the sampling gear between habitats, or differential periods of rearing by some species. That is, species such as chubs may have entered wetlands before our sampling began. Most of the fish collected during both years were either juveniles or larvae. This pattern suggest that suckers and other fish species using WRP wetlands habitats are doing so at early developmental stages, then migrating to the river or Upper Klamath Lake. Use of wetland habitats for rearing would be consistent with behavior of other species from a variety of locations

The 11 species of fish we documented using wetlands in the UKRB suggests these WRP wetlands are providing a valuable ecosystem service. We suspect that WRP wetlands are functioning similar to other riparian wetlands on the Sprague River. The fish community of the UKRB, which includes Upper Klamath Lake, includes 18 species of native fishes and 18 species of nonnative fishes, some of which are strains or subspecies of the native species (National Research Council, 2007). Our results suggest a high proportion of the UKRB fish community, including important endangered species, use riparian WRP wetland habitat along the Sprague River.

\section{References Cited}

Allan, J.D., and Castillo, M.M., 2007, Stream ecology: structure and function of running waters, second edition. Springer, Dordrecht, The Netherlands, 436 p.

Allen-Wardell, G., Bernhardt, P., Bitner, R., Burquez, A., Buchmann, S., Cane, J., Cox, P.A., Dalton, V., Feinsinger, P., Ingram, M., Inouye, D., Jones, C.E., Kennedy, K., Kevan, P., Koopowitz, H., Medellin, R., Medellin-Morales, S., and Nebhan, G.P., 1998, The potential consequences of pollinator declines on the conservation of biodiversity and stability of food crop yields: Conservation Biology, v. 12, no. 1, p. 8-17.

Altig, R., McDiarmid, R.W., Nichols, K.A., and Ustach, P.C., 2007, Tadpoles of the United States and Canada: a tutorial and key: U.S. Geological Survey, Patuxent Wildlife Research Center, Laurel, Maryland, accessed September 16, 2011, at http://www.pwrc.usgs.gov/tadpole/.

Association of Analytical Communities, 1997, Official method 972.43: Microchemical determination of carbon, hydrogen, and nitrogen, automated method, in Kuniff, P., ed., Official methods of analysis of AOAC International, 16th edition: AOAC International, Arlington, Virginia, p. 5-6.

Ballantine, K., and Schneider, R., 2009, Fifty-five years of soil development in restored freshwater depressional wetlands: Ecological Applications, v. 19, p. 1467-1480.

Binford, L.C., 1986, Checklist of California birds 1986: Western Birds, v. 17, p. 1-16.

Boyd, M., Kirk, S., Wiltsey, M., and Kasper, B., 2002, Upper Klamath Lake drainage Total Maximum Daily Load (TMDL) and Water Quality Management Plan (WQMP): State of Oregon Department of Environmental Quality, Portland, Oregon, accessed September 16, 2011, at http://www.deq.state.or.us/wq/tmdls/docs/klamathbasin/ukldrainage/tmdlwqmp.pdf.

Bishel-Machung, L., Brooks, R.P., Yates, S.S., and Hoover, K.L., 1996, Soil properties of reference wetlands and wetland creation projects in Pennsylvania: Wetlands, v. 16, p. 530-541. 
Boomer, K.B., Weller, D.E., and Jordan, T.E., 2008, Empirical models based on the universal soil loss equation fail to predict sediment discharges from Chesapeake Bay catchments: Journal of Environmental Quality, v. 37, p. 79-89.

Bremner, J.M., 1996, Nitrogen-total, in Sparks, D.L., ed., Methods of soil analysis: part 3: chemical methods: Soil Science Society of America Book Series 5, Soil Science Society of America and American Society of Agronomy, Madison, Wisconsin, p. 1085-1121.

California Association of Resource Conservation Districts, 2010, Grassland RCD: California Association of Resource Conservation Districts, accessed September 16, 2011, at http://www.carcd.org/directory.php?rcdid=489.

California Department of Fish and Game, 2009, State and federally listed endangered and threatened animals of California: California Department of Fish and Game, accessed September 16, 2011, at http://www.dfg.ca.gov/biogeodata/cnddb/pdfs/TEAnimals.pdf.

California Department of Water Resources, 2005, Flood warnings: responding to California's flood crisis: accessed September 16, 2011, at http://www.water.ca.gov/pubs/flood/flood_warnings__responding_to_california\%27s_flood_ crisis/011005floodwarnings.pdf.

California Native Plant Society, 2004, Vegetation rapid assessment protocol: California Native Plant Society, accessed September 16, 2011, at http://www.cnps.org/cnps/vegetation/pdf/rapid_assessment_protocol.pdf.

Carpenter, S.R., Caraco, N.F., Correll, D.L., Howarth, R.W., Sharpley, A.N., and Smith, V.H., 1998, Nonpoint pollution of surface waters with phosphorus and nitrogen: Ecological Applications, v. 8, no. 3, p. 559-568.

Carpenter, K.D., Snyder, D.T., Duff, J.H., Triska, F.J., Lee, K.K., Avanzino, R.J., and Sobieszczyk, S., 2009, Hydrologic and water-quality conditions during restoration of the Wood River Wetland, Upper Klamath River basin, Oregon, 2003-05: U.S. Geological Survey Scientific Investigations Report 2009-5004, 66 p. (Also available at http://pubs.usgs.gov/sir/2009/5004.)

Central Valley Joint Venture, 2006a, Central Valley Joint Venture implementation planConserving Bird Habitat: U.S. Fish and Wildlife Service, Sacramento, California, accessed September 16, 2011, at http://www.centralvalleyjointventure.org/assets/pdf/CVJV_fnl.pdf.

Central Valley Joint Venture, 2006b, Shapefile format, Basins of the Central Valley from the Central Valley Joint Venture Implementation Plan-Conserving Bird Habitat: U.S. Fish and Wildlife Service, Sacramento, California, accessed September 16, 2011, at http://www.centralvalleyjointventure.org/assets/pdf/CVJV_fnl.pdf.

Collins, M.E., and Kuehl, R.J., 2001, Organic matter accumulation in organic soils, in Richardson, J.L., and Vepraskas, M.J., eds., Wetland soils: genesis, hydrology, landscapes, and classification: Lewis Publishers, CRC Press, Boca Raton, Florida, p. 137-162.

Cronk, J.K., and Fennessy, M.S., 2001, Wetland plants: biology and ecology: Lewis Publishers, CRC Press, Boca Raton, Florida.

Dahl, T.E., 2006, Status and trends of wetlands in the conterminous United States 1998 to 2004: U.S. Fish and Wildlife Service, Washington, DC, accessed September 16, 2011, at http://www.fws.gov/wetlands/_documents/gSandT/NationalReports/StatusTrendsWetlandsCon terminousUS1998to2004.pdf.

Daubenmire, R.F., 1959, Plants and environment: John Wiley \& Sons, Inc., New York, New York. 
Dennis, N.B., Marcus, M.L., and Hill, H., 1984, Status and trends of California wetlands: Final report prepared for the California Assembly, Resources Subcommittee.

Denver, R.J., 1998, Hormonal correlates of environmentally induced metamorphosis in the western spadefoot toad, Scaphiopus hammondii: General and Comparative Endocrinology, v. 110, p. 326-336.

Diamond, J.M., 1996, A-bombs against amphibians: Nature, v. 383, p. 386-387.

Dimmitt, M.A., and Ruibal, R., 1980, Environmental correlates of emergence in spadefoot toads (Scaphiopus): Journal of Herpetology, v. 14, no. 1, p. 21-29.

Dorcas, M.E., Price, S.J., Walls, S.C., and Barichivich, W.J., 2009, Auditory monitoring of anuran population, in Dodd, K., ed., Conservation and ecology in amphibians: Oxford University Press, Oxford, United Kingdom, p. 281-298.

Engilis, A., Jr., 1995, Wildlife resources of the Central Valley, California, birds - part 2: permanent and summer residents: Valley Habitats Technical Series Number 5, Ducks Unlimited, Inc., Sacramento, California.

Euliss, N.D., Jr., Gleason, R.A., Olness, A., McDougal, R.L., Murkin, H.R., Robarts, R.D., Bourbonniere, R.A., and Warner, B.G., 2006, North American prairie wetlands are important nonforested land-based carbon storage sites: Science of the Total Environment, v. 361, p. 179188.

Euliss, N.D., Jr., J.W., Fredrickson, L.H., Mushet, D.M., Laubhan, M.K., Swanson, G.A., T.C. Winter, T.C., Rosenberry, D.O., and Nelson, R.D., 2004, The wetland continuum: A conceptual framework for interpreting biological studies: Wetlands, v. 24, p. 448-458.

Fisher, J., and Acreman, M.C., 2004, Wetland nutrient removal: a review of the evidence: Hydrology and Earth System Science, v. 8, p. 673-685.

Fisher, R.N., and Shaffer, H.B., 1996, The decline of amphibians in California's Great Central Valley: Conservation Biology, v. 10, p. 1387-1397.

Gannett, M., Lite, K.E., Jr., La Marche, J.L., Fisher, B., and Polette, D.J., 2010, Ground-water hydrology of the Upper Klamath Basin, Oregon and California: U.S. Geological Survey Scientific Investigations Report 2007-5050, version 1.1, 84 p.

Gavlak, R.G., Horneck, D.A., and Miller, R.O., 1994a, Total nitrogen in botanical materials: combustion method, in Gavlak, R.G., Horneck, D.A., and Miller, R.O., eds., Soil and plant tissue reference methods for the western region: Western Regional Publication, University of Alaska, Fairbanks, Alaska, p. 45-46.

Gavlak, R.G., Horneck, D.A., and Miller, R.O., 1994b, Phosphorus, potassium, calcium, magnesium, sodium, boron, zinc, copper, iron and manganese of botanical materials: dry ash, in Gavlak, R.G., Horneck, D.A., and Miller, R.O., eds., Soil and plant tissue reference methods for the western region: Western Regional Publication, University of Alaska, Fairbanks, Alaska, p. 49-51.

Ghioca-Robrecht, R., Anderson, T.A., McMurry, S.T., and Smith, L.M., 2010, Lipid mass and fatty acid composition of Spea spp. in Playa wetlands as influenced by land use: Wetlands, v. 30, no. 2, p. 220-230.

Gilmer, D.S., Gonzales, K.A., Wolder, M.A., and Graves, N.R., 1998, Nongame and upland gamebird surveys on Sacramento Valley National Wildlife Refuges, 1986-1993: Western Birds, v. 29, p. 83-102. 
Golet, G.H., D.L. Brown, E.E. Crone, G.R. Geupel, S.E. Greco, K.D. Holl, D.E. Jukkola, G.M. Kondolf, E.W. Larsen, F.K. Ligon, R.A. Luster, M.P. Marchetti, N. Nur, B.K. Orr, D.R. Peterson, M.E. Power, W.E. Rainey, M.D. Roberts, J.G. Silveira, S.L. Small, J.C. Vick, D.S. Wilson and D.M. Wood, 2003, Using science to evaluate restoration efforts and ecosystem health on the Sacramento River Project, California, in Faber, P.M., ed., California riparian systems: processes and floodplain management, ecology and restoration: 2001 Riparian Habitat and Floodplains Conference proceedings, Riparian Habitat Joint Venture, Sacramento, California, p. 368-385.

Gray, R.L., 2005, Wetlands Reserve Program: a partnership to restore wetlands and associated habitats: U.S. Forest Service, General Technical Report PSW-GTR-191, Albany, California. Halliday, T.R., 1998, Ecology: a declining amphibian conundrum: Nature, v. 394, no. 6692, p. 418-419.

Harris, P.D., 2001, Bird community patterns of spring-seasonal and semi-permanent wetlands in the Sacramento Valley, California: Oregon State University, Corvallis, Oregon, M.S. Thesis.

Hartman, J.R., and Goldstein, J.H., 1994, The Everglades, coastal Louisiana, Galveston Bay, Puerto Rico, California’s Central Valley, western riparian areas, southeastern and western Alaska, The Delmarva Peninsula, North Carolina, northeastern New Jersey, Michigan and Nebraska, in Hartman, J.R., and Goldstein, J.H., eds., The impact of federal programs on wetlands volume II: U.S. Department of the Interior, Washington D.C, p. 191-212.

Hickey, C., Wood, J., Stenzel, L., DiGaudio, R., Page, G., Culp, L., Tonra, C., Kreitinger, K., and Geupel, G., 2008, Avian monitoring on private lands: measuring bird response to easement, restoration, enhancement, and incentive programs in the Central Valley, 2004-2006: PRBO Conservation Science, Petaluma, California.

Holmes, R., 2004, Monitoring of sediment-bound contaminants in the Lower Sacramento River Watershed, Surface Water Ambient Monitoring Program (SWAMP), Lower Sacramento River Watershed, final report 2004: California Environmental Protection Agency, Regional Water Quality Control Board, Central Valley Region, Rancho Cordova, California.

Homer, C., Huang, C., Yang, L., Wylie, B., and Coan, M., 2004, Development of a 2001 national landcover database for the United States: Photogrammetric Engineering and Remote Sensing, v. 70, p. 829-840.

International Union for Conservation of Nature, 2006, 2006 IUCN Red List of Threatened Species: accessed September 16, 2011, at http://www.iucnredlist.org.

Jennings, M.R., and Hayes, M.P., 1994, Amphibian and reptile species of special concern in California: California Department of Fish and Game, Inland Fisheries Division, Rancho Cordova, California.

Kadlec, R.H., and Knight, R.L., 1996, Treatment wetlands: Lewis Publishers, New York, New York.

Kantrud, H.A., and Newton, W.E., 1996, A test of vegetation-related indicators of wetland quality in the prairie pothole region: Journal of Aquatic Ecosystem Health, v. 5, p. 177-191.

Kayranli, B., Scholz, M., Mustafa, A., and Hedmark, A., 2010, Carbon storage and fluxes within freshwater wetlands: a critical review: Wetlands, v. 30, p. 111-124.

King, S.L., Twedt, D.J., and Wilson, R.R., 2006, The role of the Wetland Reserve Program in Conservation Efforts in the Mississippi River alluvial valley: Wildlife Society Bulletin, v. 34, no. 4, p. 914-920. 
Klein, A.M., Vaissiere, B., Cane, J.H., Steffan-Dewenter, I., Cunningham, S.A., Kremen, C., and Tschamtke, T., 2007, Importance of crop pollinators in changing landscapes for world crops:

Proceedings of the Royal Society of Biology B-Biological Sciences, v. 274, p. 303-313.

Knopf, F.L., and Rupert, J.R., 1995, Habits and habitats of Mountain Plovers in California: The Condor, v. 97, p. 743-751.

Kremen, C., Williams, N.M., and Thorp, R., 2002, Crop pollination from native bees at risk from agricultural intensification: Proceedings of the National Academy of Sciences, v. 99, p. 1681216816.

Kremen, C., Williams, N.M., Bugg, R.L., Fay, J.P., and Thorp, R.W., 2004, The area requirements of an ecosystem service: crop pollination by native bee communities in California: Ecology Letters, v. 7, no. 11, p. 1109-1119.

Kremen, C., Williams, N.M., Aizen, M.A., Gremmil-Herren, B., LeBuhn, G., Minckley, R., Packer, L., Potts, S.G., Roulston, T., Steffan-Dewenter, I., Vazquez, D.P., Winfree, R., Adams, L., Crone, E.E., Greenleaf, S.S., Keitt, T.H., Klein, A., Regetz, J., and Ricketts, T.H., 2007, Pollination and other ecosystem services produced by mobile organisms: a conceptual framework for the effects of land-use change: Ecology Letters, v. 10, p. 299-314.

Kroodsma, D.A., and Field, C.B., 2006, Carbon sequestration in California agriculture, 19802000: Ecological Applications, v. 16, p. 1975-1985.

Kuo, S., 1996, Phosphorus, in Sparks, D.L., ed., Methods of soil analysis: part 3: chemical methods: Soil Science Society of America and American Society of Agronomy, Madison, Wisconsin, p. 869-920.

Lal, R., 2002, Why carbon sequestration in agricultural soils? in Kimble, J.M., Lal, R., and Follett, R.F., eds., Agricultural practices and policies for carbon sequestration in soil: Lewis Publishers, Boca Raton, Florida, p. 21-30.

Larney, F.J., Bremmer, E., Janzen, H.H., Johnston, A.M., and Lindwall, C.W., 1997, Changes in total, mineralizable and light fraction soil organic matter with cropping and tillage intensities in semiarid southern Alberta, Canada: Soil and Tillage Research, v. 42, p. 229-240.

Laubahn, M.K., Kermes, K.E., and Gleason, R.A., 2008, Proposed approach to assess potential wildlife habitat suitability on program lands, in Gleason, R.A., Laubhan, M.K., and Euliss, N.H., Jr., eds., Ecosystem services derived from wetland conservation practices in the United States Prairie Pothole Region with an emphasis on the U.S. Department of Agriculture Conservation Reserve and Wetlands Reserve Programs: U.S. Geological Survey Professional Paper 1745, 58 p. (Also available at http://pubs.usgs.gov/pp/1745/.)

LeBuhn, G., Griswold, T., Minckley, R., Droege, S., Roulston, T., Cane, J., Parker, F., Buchmann, S., Tepedino, V., Williams, N., Kremen, C., and Messenger, O., 2003, A standardized method for monitoring bee populations - the bee inventory (BI) plot, draft 2003: San Francisco State University, San Francisco, California, accessed September 16, 2011, at http://online.sfsu.edu/ beeplot/pdfs/Bee\%20Plot\%202003.pdf.

Liu, Y., Yang, W., and Wang, X., 2008, Development of a SWAT extension module to simulate riparian wetland hydrologic processes at a watershed scale: Hydrological Processes, v. 22, p. 2901-2915.

Long, R.F., Hanson, B.R., Fulton, A.E., and Weston, D.P., 2010, Mitigation techniques reduce sediment in runoff from furrow-irrigated cropland: California Agriculture, v. 64, no. 3, p. 135140, accessed September 16, 2011, at http://escholarship.org/uc/item/3fb1p5z9.

McGregor, S.E., 1976, Insect Pollination of Cultivated Crops: U.S. Department of Agriculture, Agricultural Research Service, Agriculture Handbook 496, Washington, D.C. 
McKee, L.J., Ganju, N.K., and Schoellhamer, D.H., 2006, Estimates of suspended sediment entering San Francisco Bay from the Sacramento and San Joaquin Delta, San Francisco Bay, California: Journal of Hydrology, v. 323, p. 335-352.

Meyer, G.A., and Keliher, P.N., 1992, An overview of analysis by inductively coupled plasmaatomic emission spectrometry, in Montaser, A., and Golightly, D.W., eds., Inductively coupled plasmas in analytical atomic spectrometry: Wiley-VCH Publishers Inc., New York, New York, p. 473-516.

Mitsch, W.J., and Gosselink, J.G., 2007, Wetlands, fourth edition: John Wiley \& Sons, Inc., New York, New York.

Morey, S.R., 2005, Spea hammondii (Baird, 1859 “1857”), western spadefoot, in Lannoo, M., ed., Amphibian declines: the conservation status of United States species: University of California Press, Berkeley and Los Angeles, California, p. 514-517.

National Research Council, 2007, Hydrology, ecology, and fishes of the Klamath River Basin: National Academies Press, Washington, DC.

Nelson, D.W., and Sommers, L.E., 1996, Total carbon, organic carbon, and organic matter, in Sparks, D.L., ed., Methods of soil analysis, part 3: Chemical Methods, Soil Science Society of America and American Society of Agronomy, Madison, Wisconsin, p. 961-1010.

PRISM Climate Group, 2006, United States average monthly or annual precipitation, 19712000: Oregon State University, accessed September 11, 2011, at http://www.prismclimate.org. Ralph, C.J., Droege, S., and Sauer, J.R., 1995, Monitoring bird populations by point counts: U.S. Forest Service, General Technical Report PSW-GTR-149, Albany, California.

Reddy, K.R., Kadlec, R.H., Flaig, E., and Gale, P.M., 1999, Phosphorous retention in streams and wetlands: a review: Critical Reviews in Environmental Science and Technology, v. 29, p. 83-146.

Reed, J.M., Warnock, N., and Oring. L.W., 1997, Censusing shorebirds in the western Great Basin of North America: International Wader Studies, v. 9, p. 29-36.

Richardson, C.W., Bucs, D.A., and Sadler, E.J., 2008, The Conservation Effects Assessment Project benchmark watersheds: synthesis of preliminary findings: Journal of Soil and Water Conservation, v. 63, p. 590-604.

Robel, R.J., Briggs, J.N., Dayton, A.D., and Hulbert, L.C., 1970, Relationships between visual obstruction measurements and weight of grassland vegetation: Journal of Range Management, v. 23, p. 295-297.

Saggar, R.N., Yeates, G.W., and Shepherd, T.G., 2001, Cultivation effects on soil biological properties, microfauna, and organic matter dynamics in eutric gleysol and gleyic luvisol soils in New Zealand: Soil and Tillage Research, v. 58, p. 55-68.

Sah, R.N., and Miller, R.O., 1992, Spontaneous reaction for acid dissolution of biological tissues in closed vessels: Analytical Chemistry, v. 64, p. 230-233.

Schlesinger, W.H., 1984, Soil organic matter: a source of atmospheric $\mathrm{CO}_{2}$, in Woodwell, G.M., ed., The role of terrestrial vegetation in the global carbon cycle: measurement by remote sensing: John Wiley and Sons, New York, New York, p. 111-127.

Schlesinger, W.H., 1997, Biogeochemistry: an analysis of global change: Academic Press, San Diego, California.

Schoenherr, A.A., 1992, A natural history of California: University of California Press, Berkeley, California.

Shuford, W.D., Page, G.W., and Kjelmyr, J.E., 1998, Patterns and dynamics of shorebird use of California's Central Valley: The Condor, v. 100, p. 227-244. 
Shuford, W.D., and Gardali, T., eds., 2008, California bird species of special concern: a ranked assessment of species, subspecies, and distinct populations of birds of immediate conservation concern in California, studies of western birds no. 1. Western Field Ornithologists, Camarillo, California, and California Department of Fish and Game, Sacramento, California.

Smith, W.D., Rollins, G.L., and Shinn, R., 1995, A guide to wetland habitat management in the Central Valley: California Department of Fish and Game and California Waterfowl Association, Sacramento, California.

Stebbins, R.C., 2003, A field guide to western reptiles and amphibians: Houghton Mifflin Harcourt, New York, New York.

Stewart, R.E., and Kantrud, H.A., 1971, Classification of natural ponds and lakes in the glaciated prairie region: U.S. Fish and Wildlife Service, Resource Publication 92 (Version 16APR1998), Washington, D.C., accessed September 16, 2011, at http://www.npwrc.usgs.gov/resource/wetlands/pondlake/index.htm.

SYSTAT 2007. SYSTAT software incorporated. San Jose, CA

Tomelleri, J., 2007a, Shortnose sucker (Chasmistes brevirostris): five-year review summary and evaluation: U.S. Fish and Wildlife Service, Klamath Falls, Oregon, accessed September 16, 2011, at http://www.fws.gov/klamathfallsfwo/news/Suckers/SNS\%205year\%20Status\%20Review\%20\%2807-10-07\%29.pdf.

Tomelleri, J., 2007b, Lost River sucker (Deltistes luxatus): five-year review summary and evaluation: U.S. Fish and Wildlife Service, Klamath Falls, Oregon, accessed at http://www.fws.gov/klamathfallsfwo/news/Suckers/LRS\%205year\%20Status\%20Review\%20\%2807-17-07\%29.pdf.

U.S. Department of Agriculture, 1954, Alkaline-earth carbonates by gravimetric loss of carbon dioxide, in Richards, L.A., ed., Diagnosis and improvement of saline and alkali soils: U.S. Department of Agriculture, Handbook 60, Washington, D.C., p. 105.

U.S. Department of Agriculture, 1996, Soil survey laboratory methods manual: U.S. Department of Agriculture, Natural Resources Conservation Service, Soil Survey Investigations Report no. 42 version 3.0, Washington, DC.

U.S. Department of Agriculture, 2006, Conservation effects assessment project national assessment wetlands component: U.S. Department of Agriculture, Natural Resources Conservation Service, Resource Inventory and Assessment Division, Beltsville, Maryland.

U.S. Environmental Protection Agency, 2001, Ambient water quality criteria recommendations: information supporting the development of state and tribal nutrient criteria: Environmental Protection Agency, Report 822-B-00-022, Washington, DC.

U.S. Fish and Wildlife Service, 2005, Recovery plan for vernal pool ecosystems of California and southern Oregon: U.S. Fish and Wildlife Service, Portland, Oregon, accessed September 16, 2011, athttp://www.fws.gov/sacramento/es/es_recovery_vernal-pool-recovery.htm

U.S. Fish and Wildlife Service, 2008, Birds of Conservation Concern 2008: U.S. Fish and Wildlife Service, Division of Migratory Bird Management, Arlington, Virginia, accessed September 16, 2011, at http://www.fws.gov/migratorybirds.

U.S. Fish and Wildlife Service, 2010, Wetlands mapper: accessed September 16, 2011, at http://www.fws.gov/wetlands/Data/Mapper.html.

Vache, K., and Eilers, J., 2005, Application of the Soil Water Assessment Toolkit (SWAT) model to the Sprague River watershed: Report of MaxDepth Aquatics, Inc. to the Klamath Tribes, Chiloquin, Oregon.

VanRees-Siewert, K.L., and Dinsmore, J.J., 1996, Influence of wetland age on bird use of restored wetlands in Iowa: Wetlands, v. 16, p. 577-582. 
Vitousek, P.M., Aber, J.D., Howarth, R.W., Likens, G.E., Matson, P.A., Schindler, D.W., Schlesinger, W.H., and Tilman, D.G., 1997, Human alteration of the global nitrogen cycle: sources and consequences: Ecological Applications, v. 7, no. 3, p. 737-750.

Werschkull, G.D., Griggs, F.T., and Zaninovich, J.M., 1984, Tulare-basin protection plan: The California Nature Conservancy, San Francisco, California.

Winchell, M., Srinivasan, R., Di Luzio, M., and Arnold, J., 2010, ArcSWAT interface for SWAT2009: Blackland Research Center, Texas Agricultural Experimental Station, Temple, Texas. 


\section{Appendix I: Study Sites}

Table I1. Allocation of 2008 sample sites by restoration age and management intensity among subbasins within California's Central Valley.

[Management intensity categories are defined in appendix I, table I3]

\begin{tabular}{lcccc}
\hline & \multicolumn{3}{c}{ SUBBASINS } \\
\hline Management Intensity & Restoration Age $^{1}$ & Sacramento & San Joaquin & Tulare \\
\hline & & & & \\
Low $^{2}$ & $\leq 5 \mathrm{yr}$ & 4 & 1 & 3 \\
Low $^{2}$ & $>5 \mathrm{yr}$ & 4 & 0 & 3 \\
Intermediate & $\leq 5 \mathrm{yr}$ & 5 & 2 & 4 \\
Intermediate & $>5 \mathrm{yr}$ & 3 & 1 & 2 \\
High & $\leq 5 \mathrm{yr}$ & 5 & 0 & 4 \\
High & $>5 \mathrm{yr}$ & 3 & 1 & 2 \\
NWR & & 6 & -- & 5 \\
TOTALS & & 30 & 5 & 23 \\
\hline
\end{tabular}

${ }^{1}$ Refers to 2008 less years since initial earthwork carried out.

${ }^{2}$ Low management sites included unrestored sites, where no conservation practices were applied as of July 2008.

${ }^{3}$ National Wildlife Refuges: Sacramento, Kern, and Pixley. All are high management intensity, > 5 yr. 
Table 12. Allocation of 2009 sample sites by restoration age and management intensity among subbasins within California's Central Valley.

[Management intensity categories are defined in appendix I, table I3]

\begin{tabular}{lcccc}
\hline \multicolumn{5}{c}{ SUBBASINS } \\
\hline Management Intensity & Restoration Age ${ }^{1}$ & Sacramento & San Joaquin & Tulare \\
\hline & & & & \\
Low $^{2}$ & $\leq 5 \mathrm{yr}$ & 3 & 1 & 4 \\
Low & $>5 \mathrm{yr}$ & 4 & 0 & 2 \\
Intermediate & $\leq 5 \mathrm{yr}$ & 5 & 2 & 7 \\
Intermediate & $>5 \mathrm{yr}$ & 3 & 1 & 2 \\
High & $\leq 5 \mathrm{yr}$ & 4 & 0 & 2 \\
High & $>5 \mathrm{yr}$ & 5 & 1 & 4 \\
NWR & & 1 & -- & 4 \\
TOTALS & & 25 & 5 & 25 \\
\hline
\end{tabular}

${ }^{1}$ Refers to 2009 less years since initial earthwork carried out.

${ }^{2}$ Low management sites included unrestored sites, where no conservation practices were applied as of December 2009.

${ }^{3}$ National Wildlife Refuges: Colusa, Kern, and Pixley. All are high management intensity, > 5 yr.

Table 13. Criteria for classification into the three management intensity categories.

\begin{tabular}{ll}
\hline \multicolumn{1}{c}{ Management Intensity } & \multicolumn{1}{c}{ Criteria } \\
\hline Low/ None & $\begin{array}{l}\text { No active management following restoration or less than } 50 \% \text { of } \\
\text { time since restoration. No recent flooding or drainage. }\end{array}$ \\
Intermediate & $\begin{array}{l}\text { Flooded, drained annually or more than } 50 \text { percent of time since } \\
\text { restoration. Intermittent weed control and emergent cover } \\
\text { management. }\end{array}$ \\
& $\begin{array}{l}\text { Flooded, drained annually since restoration. Regular weed control, } \\
\text { moist soil management, emergent cover. Mowed, disked, burned, } \\
\text { grazed, chemical weed control. }\end{array}$ \\
\hline
\end{tabular}


Table 14. CEAP sites and survey types, 2008-2009.

[Bold sites were included in soils analysis by Judith Drexler. Abbreviations are: $\mathrm{S}=$ soil, $\mathrm{VH}=$ vegetation habitat, $\mathrm{VB}=$ vegetation biomass, $\mathrm{A}=$ amphibian, $\mathrm{Be}=$ bees, $\mathrm{Bi}=$ birds, $\mathrm{F}=$ fish, $\mathrm{Adj}=$ adjacent agriculture and $\mathrm{FS}=$ flood water storage]

\begin{tabular}{|c|c|c|c|c|c|c|c|c|c|c|c|c|c|c|c|}
\hline \multirow[t]{2}{*}{ CEAP site code } & \multicolumn{6}{|c|}{2008} & \multicolumn{9}{|c|}{2009} \\
\hline & $\mathrm{S}$ & VH & VB & $\bar{A}$ & $\mathrm{Be}$ & $\mathrm{Bi}$ & $\mathrm{S}$ & $\overline{\mathrm{VH}}$ & VB & $\bar{A}$ & $\mathrm{Be}$ & $\mathrm{Bi}$ & $F$ & Adj & FS \\
\hline SAC-1 & -- & -- & -- & -- & -- & -- & -- & -- & -- & -- & $\mathrm{X}$ & -- & -- & -- & -- \\
\hline SAC-2 & X & X & X & X & X & X & -- & -- & -- & -- & -- & -- & -- & -- & -- \\
\hline SAC-3 & -- & $\mathrm{X}$ & $\mathrm{X}$ & $\mathrm{X}$ & $\mathrm{X}$ & $\mathrm{X}$ & -- & -- & -- & -- & -- & -- & -- & -- & -- \\
\hline SAC-4 & -- & -- & -- & -- & $\mathrm{X}$ & -- & -- & -- & -- & -- & -- & -- & -- & -- & -- \\
\hline SAC-5 & $X$ & $X$ & $\mathrm{X}$ & $\mathrm{X}$ & $X$ & -- & -- & -- & -- & -- & -- & -- & -- & -- & -- \\
\hline SAC-6 & -- & -- & -- & X & -- & -- & -- & -- & -- & -- & -- & -- & -- & -- & -- \\
\hline SAC-7 & -- & $X$ & $\mathrm{X}$ & -- & -- & -- & -- & -- & -- & -- & -- & -- & -- & -- & -- \\
\hline SAC-8 & -- & $X$ & $\mathrm{X}$ & $\mathrm{X}$ & $X$ & -- & -- & -- & -- & -- & -- & -- & -- & -- & -- \\
\hline SAC-9 & -- & -- & -- & $X$ & -- & -- & -- & -- & -- & -- & -- & -- & -- & -- & -- \\
\hline SAC-10 & $X$ & $X$ & $\mathrm{X}$ & $X$ & $X$ & $\mathrm{X}$ & $\mathrm{X}$ & $\mathrm{X}$ & $X$ & -- & $\mathrm{X}$ & $X$ & -- & $X$ & -- \\
\hline SAC-11 & $\mathrm{X}$ & $\mathrm{X}$ & $\mathrm{X}$ & $X$ & $X$ & $\mathrm{X}$ & -- & -- & -- & -- & $\mathrm{X}$ & -- & -- & -- & -- \\
\hline SAC-12 & $X$ & $X$ & $\mathrm{X}$ & $X$ & $X$ & -- & -- & -- & -- & -- & $\mathrm{X}$ & -- & -- & -- & -- \\
\hline SAC-13 & -- & -- & -- & $X$ & -- & $\mathrm{X}$ & $\mathrm{X}$ & $\mathrm{X}$ & $\mathrm{X}$ & -- & -- & $X$ & -- & -- & -- \\
\hline SAC-14 & $X$ & $X$ & $X$ & $\mathrm{X}$ & $X$ & $X$ & -- & -- & -- & -- & -- & -- & -- & -- & -- \\
\hline SAC-15 & $X$ & $X$ & $\mathrm{X}$ & $X$ & $X$ & $X$ & -- & -- & -- & -- & -- & -- & -- & -- & -- \\
\hline SAC-16 & -- & -- & -- & -- & -- & $\mathrm{X}$ & $\mathrm{X}$ & $\mathrm{X}$ & $X$ & -- & -- & $X$ & -- & -- & -- \\
\hline SAC-17 & -- & -- & -- & -- & -- & -- & $\mathrm{X}$ & $\mathrm{X}$ & $X$ & -- & -- & -- & -- & -- & -- \\
\hline SAC-18 & -- & -- & -- & -- & -- & -- & $\mathrm{X}$ & $\mathrm{X}$ & $X$ & -- & -- & -- & -- & $X$ & $\mathrm{X}$ \\
\hline SAC-19 & -- & -- & -- & -- & -- & -- & $\mathrm{X}$ & $\mathrm{X}$ & $X$ & -- & -- & -- & -- & $X$ & -- \\
\hline SAC-20 & $X$ & $X$ & $X$ & $X$ & $\mathrm{X}$ & $X$ & $X$ & $X$ & -- & -- & $\mathrm{X}$ & $X$ & -- & $X$ & -- \\
\hline SAC-21 & $X$ & $\mathrm{X}$ & $\mathrm{X}$ & $X$ & $X$ & $X$ & -- & -- & -- & -- & $\mathrm{X}$ & -- & -- & -- & -- \\
\hline SAC-22 & -- & -- & -- & -- & -- & $X$ & $\mathrm{X}$ & $\mathrm{X}$ & $\mathrm{X}$ & -- & -- & $X$ & -- & -- & -- \\
\hline SAC-23 & -- & -- & -- & -- & -- & -- & $\mathrm{X}$ & $\mathrm{X}$ & $X$ & -- & -- & $X$ & -- & $X$ & $\mathrm{X}$ \\
\hline SAC-24 & -- & -- & -- & -- & -- & -- & $X$ & $X$ & $X$ & -- & -- & -- & -- & -- & $X$ \\
\hline SAC-25 & $\mathrm{X}$ & -- & -- & -- & -- & -- & -- & -- & -- & -- & -- & -- & -- & -- & -- \\
\hline SAC-26 & $X$ & $X$ & $\mathrm{X}$ & $X$ & $X$ & $\mathrm{X}$ & -- & -- & -- & -- & $\mathrm{X}$ & -- & -- & -- & -- \\
\hline SAC-27 & -- & $\mathrm{X}$ & $X$ & $X$ & $X$ & $\mathrm{X}$ & -- & -- & -- & -- & -- & -- & -- & -- & -- \\
\hline SAC-28 & $X$ & $X$ & $\mathrm{X}$ & $X$ & $X$ & $X$ & -- & -- & -- & -- & -- & -- & -- & -- & -- \\
\hline SAC-29 & -- & -- & -- & -- & -- & -- & $X$ & $X$ & -- & -- & -- & -- & -- & -- & -- \\
\hline SAC-30 & -- & -- & -- & -- & -- & -- & $X$ & $X$ & $X$ & -- & -- & -- & -- & -- & -- \\
\hline SAC-31 & $X$ & -- & -- & $X$ & $X$ & $X$ & -- & -- & -- & -- & -- & -- & -- & -- & -- \\
\hline SAC-32 & -- & -- & -- & -- & -- & -- & $\mathrm{X}$ & $\mathrm{X}$ & -- & -- & -- & $X$ & -- & -- & $\mathrm{X}$ \\
\hline SAC-33 & $X$ & $X$ & $\mathrm{X}$ & $X$ & $X$ & $\mathrm{X}$ & -- & -- & -- & -- & -- & -- & -- & -- & -- \\
\hline SAC-34 & -- & -- & -- & -- & -- & -- & -- & -- & -- & -- & $X$ & -- & -- & -- & -- \\
\hline SAC-35 & $X$ & $X$ & $X$ & $X$ & $X$ & $X$ & -- & -- & -- & -- & -- & -- & -- & -- & -- \\
\hline SAC-36 & -- & $X$ & $X$ & -- & -- & $X$ & -- & -- & -- & -- & -- & -- & -- & -- & -- \\
\hline SAC-37 & -- & -- & -- & -- & -- & -- & $\mathrm{X}$ & $\mathrm{X}$ & -- & -- & -- & $X$ & -- & -- & $\mathrm{X}$ \\
\hline SAC-38 & -- & -- & -- & -- & -- & -- & $\mathrm{X}$ & $\mathrm{X}$ & -- & -- & -- & -- & -- & $X$ & $\mathrm{X}$ \\
\hline
\end{tabular}


Table 14. (continued).

\begin{tabular}{|c|c|c|c|c|c|c|c|c|c|c|c|c|c|c|c|}
\hline \multirow[t]{2}{*}{ CEAP site code } & \multicolumn{6}{|c|}{2008} & \multicolumn{9}{|c|}{2009} \\
\hline & $\mathrm{S}$ & $\overline{\mathrm{VH}}$ & VB & $A$ & $\mathrm{Be}$ & $\mathrm{Bi}$ & $\mathbf{S}$ & $\begin{array}{l}\mathrm{VH} \\
\mathrm{n}\end{array}$ & VB & $A$ & $\mathrm{Be}$ & $\mathrm{Bi}$ & $F$ & Adj & FS \\
\hline SAC-39 & $\mathrm{X}$ & -- & -- & $\mathrm{X}$ & $\mathrm{X}$ & $\mathrm{X}$ & -- & -- & -- & -- & -- & -- & -- & -- & -- \\
\hline SAC-40 & $\mathrm{X}$ & $X$ & $\mathrm{X}$ & $\mathrm{X}$ & $\mathrm{X}$ & $\mathrm{X}$ & -- & -- & -- & -- & $\mathrm{X}$ & -- & -- & -- & -- \\
\hline SAC-41 & -- & $X$ & $\mathrm{X}$ & $\mathrm{X}$ & $\mathrm{X}$ & $\mathrm{X}$ & -- & -- & -- & -- & -- & -- & -- & -- & -- \\
\hline SAC-42 & -- & -- & -- & -- & -- & -- & $X$ & $\mathrm{X}$ & -- & -- & -- & $X$ & -- & -- & -- \\
\hline SAC-43 & -- & -- & -- & -- & -- & -- & $X$ & $X$ & -- & -- & -- & $X$ & -- & -- & -- \\
\hline SAC-44 & -- & -- & -- & -- & -- & -- & $X$ & $X$ & $\mathrm{X}$ & -- & -- & $X$ & -- & -- & $\mathrm{X}$ \\
\hline SAC-45 & -- & -- & -- & -- & -- & $\mathrm{X}$ & -- & -- & -- & -- & -- & -- & -- & -- & -- \\
\hline SAN-1 & $\mathrm{X}$ & $X$ & $X$ & $X$ & $X$ & $X$ & $X$ & $X$ & -- & -- & $\mathrm{X}$ & $X$ & -- & -- & -- \\
\hline SAN-2 & $X$ & $X$ & $\mathrm{X}$ & $X$ & $X$ & $\mathrm{X}$ & $X$ & $X$ & -- & -- & -- & $X$ & -- & -- & -- \\
\hline SAN-3 & $X$ & $X$ & $X$ & $X$ & $X$ & $X$ & $X$ & $X$ & -- & -- & $\mathrm{X}$ & $X$ & -- & -- & -- \\
\hline SAN-4 & -- & $X$ & $X$ & $X$ & $X$ & $X$ & -- & -- & -- & -- & -- & -- & -- & -- & -- \\
\hline SAN-5 & $X$ & $X$ & $X$ & $X$ & $X$ & $X$ & $X$ & $X$ & $X$ & -- & -- & $X$ & -- & -- & -- \\
\hline SAN-6 & -- & -- & -- & -- & -- & -- & $X$ & $X$ & $X$ & - & -- & $X$ & -- & -- & -- \\
\hline TUL-1 & $X$ & $X$ & $X$ & $X$ & $X$ & -- & $X$ & $X$ & $X$ & -- & $X$ & -- & -- & $X$ & -- \\
\hline TUL-2 & $X$ & $X$ & $X$ & $X$ & $X$ & -- & $X$ & $X$ & $X$ & -- & $X$ & -- & -- & $X$ & $\mathrm{X}$ \\
\hline TUL-3 & $X$ & $X$ & $\mathrm{X}$ & $X$ & $X$ & $X$ & $X$ & $X$ & $X$ & -- & $\mathrm{X}$ & -- & -- & $X$ & -- \\
\hline TUL-4 & -- & -- & -- & -- & $X$ & -- & -- & -- & -- & -- & -- & -- & -- & -- & -- \\
\hline TUL-5 & -- & -- & -- & -- & $X$ & -- & -- & -- & -- & -- & $X$ & -- & -- & -- & -- \\
\hline TUL-6 & $X$ & $X$ & $X$ & $X$ & $X$ & $X$ & $X$ & $X$ & $X$ & -- & -- & -- & -- & -- & -- \\
\hline TUL-7 & $X$ & $X$ & $X$ & $X$ & $X$ & $X$ & -- & -- & -- & -- & -- & -- & -- & -- & -- \\
\hline TUL-8 & $X$ & $X$ & $X$ & $X$ & $X$ & $X$ & -- & -- & -- & -- & -- & -- & -- & -- & -- \\
\hline TUL-9 & $X$ & $X$ & $X$ & $X$ & $X$ & $X$ & -- & -- & -- & -- & $X$ & -- & -- & -- & -- \\
\hline TUL-10 & -- & $X$ & $X$ & $X$ & $X$ & $\mathrm{X}$ & $X$ & $X$ & $X$ & -- & $X$ & -- & -- & -- & $\mathrm{X}$ \\
\hline TUL-11 & $\mathrm{X}$ & $X$ & $\mathrm{X}$ & $X$ & $X$ & $X$ & -- & -- & -- & -- & $\mathrm{X}$ & -- & -- & -- & -- \\
\hline TUL-12 & -- & -- & -- & -- & -- & -- & $X$ & $X$ & -- & - & -- & -- & -- & $X$ & -- \\
\hline TUL-13 & -- & -- & -- & -- & $X$ & -- & $X$ & $X$ & -- & $X$ & -- & -- & -- & $X$ & -- \\
\hline TUL-14 & -- & -- & -- & -- & -- & -- & $X$ & $X$ & $X$ & -- & -- & -- & -- & -- & $X$ \\
\hline TUL-15 & $X$ & $X$ & $X$ & $X$ & $X$ & $\mathrm{X}$ & $X$ & $X$ & $X$ & -- & -- & -- & -- & -- & -- \\
\hline TUL-16 & -- & -- & -- & $X$ & -- & $X$ & -- & -- & -- & -- & -- & -- & -- & -- & -- \\
\hline TUL-17 & $\mathrm{X}$ & $\mathrm{X}$ & $X$ & -- & $X$ & -- & -- & -- & -- & -- & $X$ & -- & -- & -- & -- \\
\hline TUL-18 & -- & -- & -- & -- & -- & -- & $X$ & $X$ & $X$ & -- & -- & -- & -- & -- & -- \\
\hline TUL-19 & -- & -- & -- & -- & -- & -- & $X$ & $X$ & -- & -- & -- & -- & -- & -- & -- \\
\hline TUL-20 & -- & -- & -- & -- & -- & -- & $X$ & $X$ & -- & -- & -- & -- & -- & $X$ & -- \\
\hline TUL-21 & -- & -- & -- & -- & -- & -- & -- & -- & -- & -- & $X$ & -- & -- & -- & -- \\
\hline TUL-22 & $X$ & $X$ & $\mathrm{X}$ & $X$ & $X$ & $\mathrm{X}$ & -- & -- & -- & -- & -- & -- & -- & -- & -- \\
\hline TUL-23 & $\mathrm{X}$ & $\mathrm{X}$ & $\mathrm{X}$ & $X$ & $X$ & $X$ & $X$ & $X$ & -- & $X$ & $X$ & -- & -- & $\mathrm{X}$ & -- \\
\hline TUL-24 & $X$ & $X$ & $X$ & -- & -- & -- & -- & $X$ & -- & $X$ & -- & -- & -- & $X$ & -- \\
\hline TUL-25 & $X$ & $X$ & $X$ & $X$ & $X$ & $X$ & -- & -- & -- & -- & $X$ & -- & -- & -- & -- \\
\hline TUL-26 & $X$ & $X$ & $\mathrm{X}$ & $X$ & $X$ & $X$ & $X$ & $X$ & $X$ & $X$ & -- & -- & -- & $X$ & -- \\
\hline TUL-27 & -- & -- & -- & -- & -- & -- & $X$ & $X$ & -- & -- & -- & -- & -- & -- & -- \\
\hline TUL-28 & -- & -- & -- & -- & -- & -- & $\mathrm{X}$ & $\mathrm{X}$ & -- & -- & -- & -- & -- & -- & -- \\
\hline
\end{tabular}


Table I-4. (concluded).

\begin{tabular}{|c|c|c|c|c|c|c|c|c|c|c|c|c|c|c|c|}
\hline \multirow[t]{2}{*}{ CEAP site code } & \multicolumn{6}{|c|}{2008} & \multicolumn{9}{|c|}{2009} \\
\hline & $\mathrm{S}$ & $\overline{\mathrm{VH}}$ & VB & $\bar{A}$ & $\mathrm{Be}$ & $\overline{B i}$ & 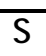 & $\overline{\mathrm{VH}}$ & VB & $\bar{A}$ & $\mathrm{Be}$ & $\overline{B i}$ & $\bar{F}$ & Adj & FS \\
\hline TUL-29 & $\mathrm{X}$ & $\mathrm{X}$ & $\mathrm{X}$ & $\mathrm{X}$ & $\mathrm{X}$ & $\mathrm{X}$ & -- & -- & -- & -- & -- & -- & -- & $\mathrm{X}$ & -- \\
\hline TUL-30 & $\mathrm{X}$ & $\mathrm{X}$ & $X$ & $\mathrm{X}$ & $\mathrm{X}$ & $\mathrm{X}$ & $\mathrm{X}$ & $\mathrm{X}$ & $\mathrm{X}$ & -- & -- & -- & -- & $\mathrm{X}$ & $\mathrm{X}$ \\
\hline TUL-31 & $\mathrm{X}$ & $\mathrm{X}$ & $\mathrm{X}$ & $\mathrm{X}$ & $\mathrm{X}$ & $\mathrm{X}$ & $\mathrm{X}$ & $\mathrm{X}$ & $X$ & -- & $\mathrm{X}$ & -- & -- & -- & $X$ \\
\hline UKRB-1 & -- & -- & -- & -- & -- & -- & X & X & -- & -- & -- & $\mathrm{X}$ & $\mathrm{X}$ & -- & -- \\
\hline UKRB-2 & -- & -- & -- & $\mathrm{X}$ & -- & -- & -- & -- & -- & -- & -- & -- & -- & -- & -- \\
\hline UKRB-3 & -- & -- & -- & -- & -- & -- & $\mathrm{X}$ & $\mathrm{X}$ & -- & -- & -- & -- & $\mathrm{X}$ & -- & -- \\
\hline UKRB-4 & -- & -- & -- & $\mathrm{X}$ & -- & -- & $\mathrm{X}$ & $X$ & -- & -- & -- & $\mathrm{X}$ & $\mathrm{X}$ & -- & -- \\
\hline UKRB-5 & -- & -- & -- & $\mathrm{X}$ & -- & -- & -- & -- & -- & -- & -- & -- & -- & -- & -- \\
\hline UKRB-6 & -- & -- & -- & $\mathrm{X}$ & -- & -- & -- & -- & -- & -- & -- & -- & -- & -- & -- \\
\hline UKRB-7 & -- & -- & -- & $\mathrm{X}$ & -- & -- & -- & -- & -- & -- & -- & -- & -- & -- & -- \\
\hline UKRB-8 & -- & -- & -- & $\mathrm{X}$ & -- & -- & -- & -- & -- & -- & -- & -- & -- & -- & -- \\
\hline UKRB-9 & -- & $X$ & -- & $X$ & -- & -- & -- & -- & -- & -- & -- & -- & -- & -- & -- \\
\hline UKRB-10 & -- & $\mathrm{X}$ & -- & $\mathrm{X}$ & -- & -- & -- & -- & -- & -- & -- & -- & -- & -- & -- \\
\hline UKRB-11 & -- & -- & -- & $\mathrm{X}$ & -- & -- & -- & -- & -- & -- & -- & -- & -- & -- & -- \\
\hline
\end{tabular}




\section{Appendix II: Soils in the California's Central Valley (CCV)}

Table II-1. Descriptions of study sites in the CCV.

[Management intensity is explained in table I3. Dominant vegetation consists of four main categories: (1) dominated by cattail (Typha spp.), Tule (Schoenoplectus spp.), rush (Juncus spp.), sedge (Cyperus spp.), (2) dominated by five horn Bassia (Bassia hyssopifolia), and/or tidy tips (Layia platyglossa), (3) dominated by upland grasses (Poa spp.), and (4) dominated by upland grasses and trees. NA = not available]

\begin{tabular}{|c|c|c|c|c|c|}
\hline Site code & Area (ha) & $\begin{array}{l}\text { Years since } \\
\text { restoration }\end{array}$ & $\begin{array}{c}\text { Management } \\
\text { intensity }\end{array}$ & $\begin{array}{l}\text { Seasonal (S) or } \\
\text { semi-permanent } \\
\text { (SP) wetland }\end{array}$ & $\begin{array}{c}\text { Dominant } \\
\text { vegetation class }\end{array}$ \\
\hline SAC-5 & 69 & 48 & High & $\mathrm{S}$ & 1 \\
\hline SAC-12 & 20.7 & 8 & Low & S & 1 \\
\hline SAC-16 & 98.6 & 6 & Medium & $S$ & 1 \\
\hline SAC-18 & 134 & 22 & High & S & 1 \\
\hline SAC-19 & 153 & 11 & Medium & S & 1 \\
\hline SAC-20 & 1.4 & 4 & High & SP & 1 \\
\hline SAC-22 & 50.8 & 9 & High & SP & 1 \\
\hline SAC-24 & 45.3 & 5 & Low & $\mathrm{S}$ & 1 \\
\hline SAC-25 & 10.8 & 1 & Low & SP & 1 \\
\hline SAC-28 & 20.3 & 2 & Low & $\mathrm{S}$ & 1 \\
\hline SAC-30 & 6.2 & 3 & Medium & SP & 1 \\
\hline SAC-33 & 207 & 2 & Medium & $\mathrm{S}$ & 1 \\
\hline SAC-35 & 18.7 & 2 & Medium & S & 3 \\
\hline SAC-37 & 66 & 4 & Medium & S & NA \\
\hline SAC-40 & 231 & 5 & High & S & 1 \\
\hline SAC-42 & 445 & 4 & High & S & 1 \\
\hline SAN-1 & 55.7 & 8 & High & S & 4 \\
\hline SAN-3 & 79.4 & 1 & Low & SP & 1 \\
\hline SAN-6 & 816 & 7 & High & $\mathrm{S}$ & 1 \\
\hline TUL-1 & 340 & 45 & High & SP & 1 \\
\hline TUL-2 & 348 & 45 & High & $\mathrm{S}$ & 1 \\
\hline TUL-3 & 66 & 45 & High & S & 1 \\
\hline TUL-7 & 113 & 9 & Low & S & 3 \\
\hline TUL-11 & 336 & 10 & Medium & S & 3 \\
\hline TUL-12 & 73.0 & 0 & Medium & S & 2 \\
\hline TUL-13 & 370 & 3 & High & S & 2 \\
\hline TUL-15 & 233 & 13 & High & S & 1 \\
\hline TUL-17 & 195 & 5 & Low & S & 3 \\
\hline TUL-18 & 51.4 & 0 & Low & S & 2 \\
\hline TUL-20 & 34.2 & 1 & Low & $S$ & 2 \\
\hline TUL-22 & 621 & 5 & Low & S & 1 \\
\hline TUL-24 & 197 & 3 & Medium & S & 2 \\
\hline TUL-26 & 246 & 3 & Medium & S & 2 \\
\hline TUL-28 & 68.2 & 4 & Medium & S & 1 \\
\hline TUL-30 & 131 & 6 & High & S & 1 \\
\hline
\end{tabular}




\section{Appendix III: Bird use in the California's Central Valley (CCV)}

Table III-1. Bird survey sites and survey type, 2008-2009.

\begin{tabular}{|c|c|c|c|c|c|c|}
\hline \multirow[b]{2}{*}{$\begin{array}{l}\text { CEAP site } \\
\text { code }\end{array}$} & \multicolumn{3}{|c|}{2008} & \multicolumn{3}{|c|}{2009} \\
\hline & $\begin{array}{l}\text { Wetland } \\
\text { Site Count }\end{array}$ & Point Count & $\begin{array}{c}\text { Area } \\
\text { Search }\end{array}$ & $\begin{array}{l}\text { Wetland } \\
\text { Site Count }\end{array}$ & Point Count & $\begin{array}{c}\text { Area } \\
\text { Search }\end{array}$ \\
\hline SAC-1 & $\mathrm{X}$ & -- & -- & -- & -- & -- \\
\hline SAC-3 & $X$ & $\mathrm{X}$ & -- & -- & -- & -- \\
\hline SAC-10 & $\mathrm{X}$ & -- & -- & $\mathrm{X}$ & -- & -- \\
\hline SAC-11 & $\mathrm{X}$ & -- & -- & -- & -- & -- \\
\hline SAC-13 & $\mathrm{X}$ & $X$ & $\mathrm{X}$ & -- & $X$ & $X$ \\
\hline SAC-14 & $\mathrm{X}$ & -- & -- & -- & -- & -- \\
\hline SAC-15 & $X$ & -- & -- & -- & -- & -- \\
\hline SAC-16 & $\mathrm{X}$ & -- & -- & $\mathrm{X}$ & -- & -- \\
\hline SAC-20 & $\mathrm{X}$ & -- & -- & -- & $X$ & -- \\
\hline SAC-21 & X & -- & -- & -- & -- & -- \\
\hline SAC-22 & $X$ & -- & -- & $X$ & -- & -- \\
\hline SAC-23 & -- & -- & -- & $\mathrm{X}$ & -- & -- \\
\hline SAC-26 & $\mathrm{X}$ & $X$ & $X$ & -- & -- & -- \\
\hline SAC-27 & $X$ & -- & -- & -- & -- & -- \\
\hline SAC-28 & X & -- & -- & -- & -- & -- \\
\hline SAC-31 & $\mathrm{X}$ & -- & -- & -- & -- & -- \\
\hline SAC-32 & -- & -- & -- & $\mathrm{X}$ & -- & -- \\
\hline SAC-33 & $\mathrm{X}$ & -- & -- & -- & -- & -- \\
\hline SAC-34 & $\mathrm{X}$ & -- & -- & -- & -- & -- \\
\hline SAC-36 & $\mathrm{X}$ & $\mathrm{X}$ & -- & -- & -- & -- \\
\hline SAC-37 & -- & -- & -- & $\mathrm{X}$ & -- & -- \\
\hline SAC-39 & $\mathrm{X}$ & $\mathrm{X}$ & -- & -- & -- & -- \\
\hline SAC-40 & $X$ & $X$ & -- & -- & -- & -- \\
\hline SAC-41 & -- & $X$ & -- & -- & -- & -- \\
\hline SAC-42 & -- & -- & -- & $\mathrm{X}$ & -- & -- \\
\hline SAC-43 & -- & -- & -- & $X$ & -- & -- \\
\hline SAC-44 & -- & -- & -- & $X$ & -- & -- \\
\hline SAC-45 & $\mathrm{X}$ & $\mathrm{X}$ & -- & -- & -- & -- \\
\hline SAN-1 & -- & $\mathrm{X}$ & -- & -- & $X$ & -- \\
\hline SAN-2 & $\mathrm{X}$ & -- & -- & $\mathrm{X}$ & -- & -- \\
\hline SAN-3 & $\mathrm{X}$ & -- & -- & $\mathrm{X}$ & -- & -- \\
\hline SAN-4 & $\mathrm{X}$ & -- & -- & -- & -- & -- \\
\hline SAN-5 & $\mathrm{X}$ & -- & -- & $\mathrm{X}$ & -- & -- \\
\hline SAN-6 & -- & -- & -- & $X$ & $X$ & -- \\
\hline TUL-1 & $X$ & -- & -- & -- & -- & -- \\
\hline TUL-6 & $\mathrm{X}$ & -- & -- & -- & -- & -- \\
\hline TUL-7 & X & -- & -- & -- & -- & -- \\
\hline
\end{tabular}


Table III-1. (concluded).

\begin{tabular}{|c|c|c|c|c|c|c|}
\hline \multirow[b]{2}{*}{$\begin{array}{l}\text { CEAP site } \\
\text { code }\end{array}$} & \multicolumn{3}{|c|}{2008} & \multicolumn{3}{|c|}{2009} \\
\hline & $\begin{array}{l}\text { Wetland } \\
\text { Site Count }\end{array}$ & Point Count & $\begin{array}{c}\text { Area } \\
\text { Search }\end{array}$ & $\begin{array}{l}\text { Wetland } \\
\text { Site Count }\end{array}$ & Point Count & $\begin{array}{c}\text { Area } \\
\text { Search }\end{array}$ \\
\hline TUL-8 & $\mathrm{X}$ & -- & -- & -- & -- & -- \\
\hline TUL-9 & $\mathrm{X}$ & -- & -- & -- & -- & -- \\
\hline TUL-10 & $X$ & -- & -- & -- & -- & -- \\
\hline TUL-11 & $\mathrm{X}$ & -- & -- & -- & -- & -- \\
\hline TUL-15 & $\mathrm{X}$ & -- & -- & -- & -- & -- \\
\hline TUL-16 & $\mathrm{X}$ & -- & -- & -- & -- & -- \\
\hline TUL-22 & $\mathrm{X}$ & -- & -- & -- & -- & -- \\
\hline TUL-23 & $\mathrm{X}$ & -- & -- & -- & -- & -- \\
\hline TUL-25 & $\mathrm{X}$ & -- & -- & -- & -- & -- \\
\hline TUL-26 & $\mathrm{X}$ & -- & -- & -- & -- & -- \\
\hline TUL-29 & $\mathrm{X}$ & -- & -- & -- & -- & -- \\
\hline TUL-30 & $\mathrm{X}$ & -- & -- & -- & -- & -- \\
\hline TUL-31 & $X$ & -- & -- & -- & -- & -- \\
\hline UKRB-1 & -- & -- & -- & -- & -- & -- \\
\hline UKRB-4 & -- & -- & -- & -- & -- & -- \\
\hline
\end{tabular}


Table III-2. List of Special Status Bird Species observed on WRP in 2008.

\begin{tabular}{ll}
\hline Bank Swallow & Riparia riparia \\
Black Tern & Chlidonias niger \\
Olive-sided Flycatcher & Contopus cooperi \\
Bald Eagle & Haliaeetus leucocephalus \\
Burrowing Owl & Athene cunicularia \\
Golden Eagle & Aquila chrysaetos \\
Loggerhead Shrike & Lanius ludovicianus \\
Northern Harrier & Circus cyaneus \\
Peregrine Falcon & Falco peregrinus \\
Swainson's Hawk & Buteo swainsoni \\
Sandhill Crane & Grus canadensis \\
Fulvous Whistling-Duck & Dendrocygna bicolor \\
Tricolored Blackbird & Agelaius tricolor \\
Yellow-headed Blackbird & Xanthocephalus xanthocephalus \\
American White Pelican & Pelecanus erythrorhynchos \\
Eared Grebe & Podiceps nigricollis \\
Redhead & Aythya americana \\
Long-billed Curlew & Numenius americanus \\
Marbled Godwit & Limosa fedoa \\
Short-billed Dowitcher & Limnodromus griseus \\
Snowy Plover & Charadrius alexandrinus \\
Whimbrel & Numenius phaeopus \\
Brewer's Sparrow & Spizella breweri \\
Grasshopper Sparrow & Ammodramus savannarum \\
Nuttall's Woodpecker & Picoides nuttallii \\
Oak Titmouse & Baeolophus inornatus \\
Vesper Sparrow & Pooecetes gramineus \\
Yellow-breasted Chat & Icteria virens \\
Yellow-billed Cuckoo & Coccyzus americanus \\
Yellow-billed Magpie & Pica nuttalli \\
Yellow Warbler & Dendroica petechia \\
\hline & \\
& \\
\hline
\end{tabular}


Table III-3. List of Special Status Bird Species observed on WRP in 2009.

\begin{tabular}{ll}
\hline Loggerhead Shrike & Lanius ludovicianus \\
Northern Harrier & Circus cyaneus \\
Swainson's Hawk & Buteo swainsoni \\
Least Bittern & Ixobrychus exilis \\
Tricolored Blackbird & Agelaius tricolor \\
Yellow-headed Blackbird & Xanthocephalus xanthocephalus \\
Long-billed Curlew & Numenius americanus \\
Whimbrel & Numenius phaeopus \\
Nuttall's Woodpecker & Picoides nuttallii \\
Oak Titmouse & Baeolophus inornatus \\
Song Sparrow & Melospiza melodia \\
Yellow-billed Cuckoo & Coccyzus americanus \\
Yellow-billed Magpie & Pica nuttalli \\
Yellow Warbler & Dendroica petechia \\
\hline
\end{tabular}




\section{Appendix IV: Reduction of Soil Loss in the California's Central Valley (CCV)}

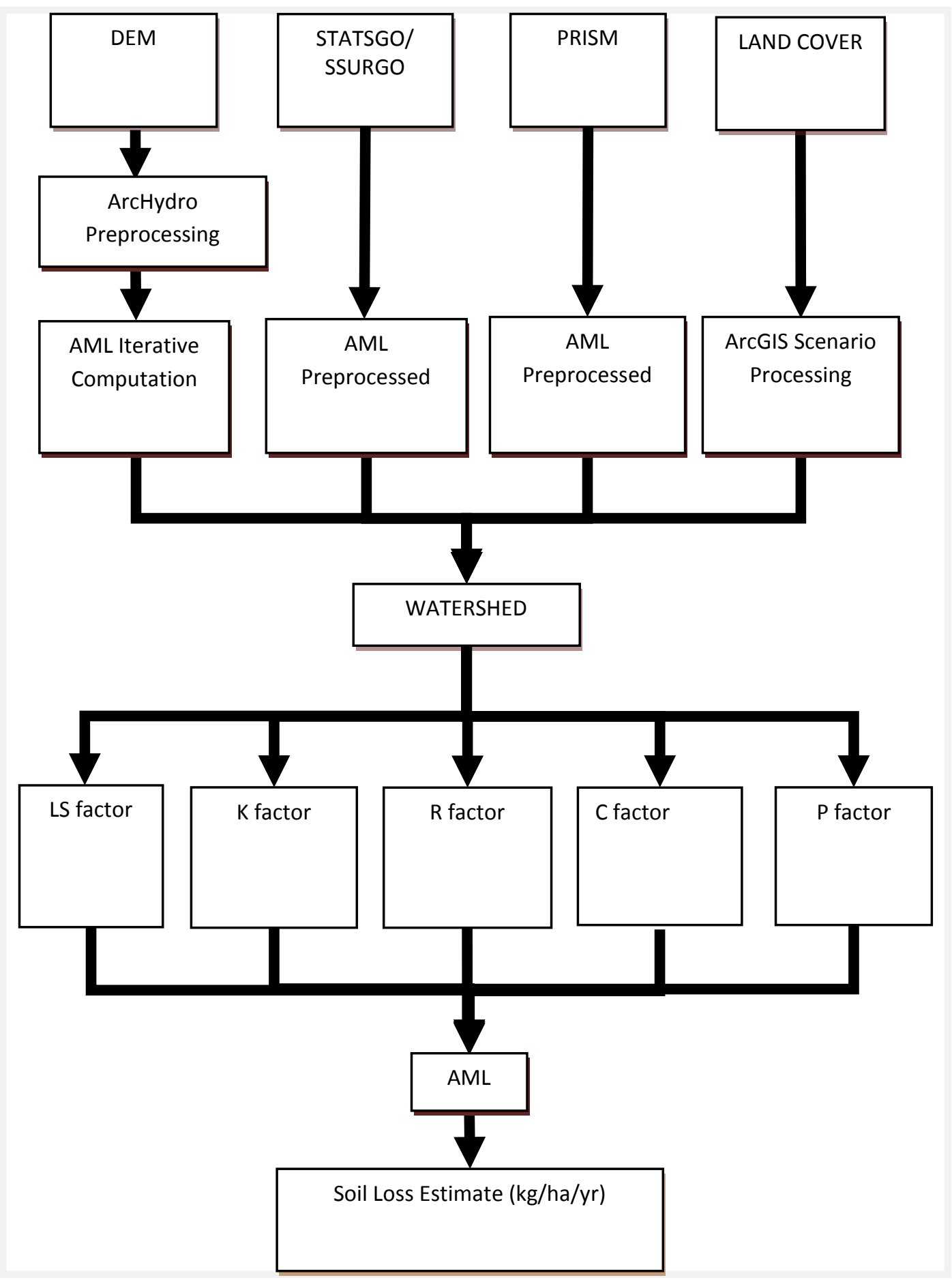

Figure IV-1. Flow chart depicting processing soil loss models. 
Table IV-1. Revised Universal Soil Loss Equation (RUSLE) factors and source data used in processing of soil loss models.

\begin{tabular}{|c|c|c|c|c|}
\hline Layer & Description & Input Layers & Processing & Programs \\
\hline LS factor & $\begin{array}{l}\text { Slope length and } \\
\text { steepness }\end{array}$ & $\begin{array}{c}\text { 30m DEM and } \\
\text { Watershed } \\
\text { Shapefile }\end{array}$ & $\begin{array}{l}\text { ArcHydro and AML } \\
\text { iterative computation }\end{array}$ & $\begin{array}{c}\text { ArcHydro and } \\
\text { AML }\end{array}$ \\
\hline $\mathrm{K}$ factor & Soil erodibility & $\begin{array}{l}\text { STATSGO/ } \\
\text { SSURGO and } \\
\text { Watershed } \\
\text { Shapefile }\end{array}$ & $\begin{array}{l}\text { Preprocessed by } \\
\text { AML program }\end{array}$ & AML \\
\hline $\mathrm{R}$ factor & Rainfall erosivity & $\begin{array}{l}\text { PRISM data and } \\
\text { Watershed } \\
\text { Shapefile }\end{array}$ & $\begin{array}{l}\text { Preprocessed by } \\
\text { AML program }\end{array}$ & AML \\
\hline C factor & Surface cover & $\begin{array}{l}\text { NLCD } 2001 \text { and } \\
\text { Watershed } \\
\text { Shapefile }\end{array}$ & $\begin{array}{l}\text { ArcGIS value } \\
\text { reclassification }\end{array}$ & ArcGIS \\
\hline $\mathrm{P}$ factor & $\begin{array}{l}\text { Conservation } \\
\text { practices }\end{array}$ & $\begin{array}{l}\text { NLCD } 2001 \text { and } \\
\text { Watershed } \\
\text { Shapefile }\end{array}$ & $\begin{array}{l}\text { ArcGIS value } \\
\text { reclassification }\end{array}$ & ArcGIS \\
\hline
\end{tabular}




\section{Appendix V: Adjacent Land Use}

Table V1. Adjacent land use at CCV study sites.

\begin{tabular}{|c|c|c|c|c|c|}
\hline \multirow[b]{2}{*}{ Site } & \multirow[b]{2}{*}{ Basin } & \multicolumn{4}{|c|}{ Immediately adjacent } \\
\hline & & North & South & East & West \\
\hline 1 & SAC & Rice & WRP & WRP & Row crops \\
\hline 2 & SAC & WRP & Rice & WRP & Row crops \\
\hline 3 & SAC & Row crops & Row crops & wetland & Row crops \\
\hline 4 & SAC & Row crops & Rice & Riparian/ forest & Rice \\
\hline 5 & SAC & Row crops & Riparian/row crops & Wetlands & Rice/ row crops \\
\hline 6 & SAC & Wetlands & Forest/ Orchards/ WRP & Wetlands/ Orchards & Row crops \\
\hline 7 & SAC & WRP & WRP & Row crops & Orchards \\
\hline 8 & SAC & Orchards & Wetlands & Row crops & WRP \\
\hline 9 & SAC & Row crops & Row crops & Row crops/ Rice & Row crops/ Rice \\
\hline 10 & SAC & Row crops & Row crops & Canal/ row crops & NWR \\
\hline 11 & SAC & Row crops & Row crops & WRP & Row crops \\
\hline 12 & SAC & Row crops & WRP & Row crops & WRP \\
\hline 13 & SAC & Row crops & Riparian wetland & Pasture & Row crops \\
\hline 14 & SAC & Row crops/ Rice & Wetland & Row crops & Pasture \\
\hline 15 & SAC & Wetlands & Wetlands & Wetlands & Wetlands \\
\hline 16 & SAC & Wetlands & Wetlands & Wetlands & Wetlands \\
\hline 17 & SAC & Wetlands & Wetlands & Wetlands & Wetlands \\
\hline 18 & SAC & Wetlands & Wetlands & Wetlands & Wetlands \\
\hline 19 & SAC & Row crops & Row crops & $\begin{array}{c}\text { Row crops/ riparian } \\
\text { wetlands }\end{array}$ & Row crops \\
\hline 20 & SAC & Row crops & Row crops & Row crops & Row crops \\
\hline 21 & SAC & -- & -- & -- & -- \\
\hline 22 & SAC & -- & -- & -- & -- \\
\hline 23 & SAN & River/ row crops & Orchards & Row crops & Orchards \\
\hline 24 & SAN & Pasture & Crops & Wetlands & Feedlot \\
\hline 25 & SAN & Wetland & WRP & Pasture & Feedlots \\
\hline 26 & SAN & Row crops & Row drops & Wetlands & Row crops \\
\hline 27 & SAN & Row crops/ pasture & Wetlands & Wetlands & Row crops \\
\hline 28 & TUL & Row crops & WRP & WRP & Row crops \\
\hline 29 & TUL & WRP & WRP & WRP & Row crops \\
\hline 30 & TUL & WRP & WRP & WRP & WRP \\
\hline 31 & TUL & Row crops & WRP & WRP & Row crops \\
\hline 32 & TUL & WRP & WRP & WRP & Row crops \\
\hline 33 & TUL & WRP & WRP & Wetland & WRP \\
\hline 34 & TUL & WRP & Grassland & Grassland & WRP \\
\hline 35 & TUL & WRP & WRP & WRP & WRP \\
\hline 36 & TUL & Wetlands & Row crops & WRP & WRP \\
\hline 37 & TUL & Pasture & Pasture/ wetland & Pasture & WRP \\
\hline 38 & TUL & NWR & NWR & NWR & NWR \\
\hline 39 & TUL & NWR & NWR & NWR & NWR \\
\hline 40 & TUL & NWR & NWR & NWR & NWR \\
\hline 41 & TUL & Grassland & WRP & Grassland & WRP \\
\hline 42 & TUL & WRP & Grassland & WRP & WRP \\
\hline 43 & TUL & WRP & WRP & WRP & Pasture \\
\hline 44 & TUL & WRP & Grassland & WRP & Pasture/ row crops \\
\hline 45 & TUL & Grassland & Grassland & Grassland & Grassland \\
\hline
\end{tabular}


Publishing support provided by the U.S. Geological Survey

Publishing Network, Tacoma Publishing Service Center

For more information concerning the research in this report, contact the California Cooperative Fish and Wildlife Research Unit U.S. Geological Survey

Humboldt State University

1 Harpst Street

Arcata, CA 95521

http://www.coopunits.org/California/ 
D

D 